\title{
EMPRESAS DE VIGILÂNCIA NO SISTEMA DE PRESTAÇÃO DE SERVIÇOS DE SEGURANÇA PATRIMONIAL PRIVADA: UMA AVALIAÇÃO DA ESTRUTURA DE GOVERNANÇA
}

\author{
ARYEVERTON FORTES DE OLIVEIRA
}

Tese apresentada à Escola Superior de Agricultura

"Luiz de Queiroz", Universidade de São Paulo, para obtenção do título de Doutor em Ciências, Área de Concentração: Economia Aplicada.

P I R A C I C A B A

Estado de São Paulo - Brasil

Novembro - 2004 


\title{
EMPRESAS DE VIGILÂNCIA NO SISTEMA DE PRESTAÇÃO DE SERVIÇOS DE SEGURANÇA PATRIMONIAL PRIVADA: UMA AVALIAÇÃO DA ESTRUTURA DE GOVERNANÇA
}

\author{
AryeVERTON FORTES DE OLIVEIRA \\ Bacharel em Ciências Econômicas
}

Orientadora: Prof ${ }^{\mathrm{a}} \mathrm{Dr}^{\mathrm{a}}$ HELOISA LEE BURNQUIST

\footnotetext{
Tese apresentada à Escola Superior de Agricultura

"Luiz de Queiroz", Universidade de São Paulo, para obtenção do título de Doutor em Ciências, Área de Concentração: Economia Aplicada.
}

P I R A C I C A B A

Estado de São Paulo - Brasil

Novembro - 2004 
Dados Internacionais de Catalogação na Publicação (CIP)
DIVISÃO DE BIBLIOTECA E DOCUMENTAÇÃO - ESALQ/USP

Oliveira, Aryeverton Fortes de

Empresas de vigilância no sistema de prestação de serviços de segurança patrimonial privada: uma avaliação da estrutura de governança / Aryeverton Fortes de Oliveira. - - Piracicaba, 2004.

$132 \mathrm{p}$.

Tese (Doutorado) - - Escola Superior de Agricultura Luiz de Queiroz, 2004.

Bibliografia.

1. Análise de correspondência 2. Empresa privada 3. Empresa de vigilância 4. Prestação de serviço 5. Teoria econômica I. Título

CDD 338.61 
À minha amada esposa, Lilian Cristina, e à nossa amada Yasmin Aos meus pais e familiares 


\section{AGRADECIMENTOS}

À Professora Dra. Heloísa Lee Burnquist, por todo suporte oferecido durante meu doutoramento e a elaboração deste trabalho.

Aos Professores Dr. Ricardo Shirota, Dr. Alexandre Lahóz Mendonça de Barros, Dr. João Gomes Martinez e o representante discente Mauro Virgino da Silva, que permitiram a continuidade deste estudo.

Aos Professores Dr. Geraldo Santana Camargo de Barros, Dra. Márcia Azanha Dias Ferraz e Dr. Eduardo Luiz Machado, por suas valiosas críticas e sugestões ao trabalho.

Ao corpo de funcionários do Departamento de Economia, Administração e Sociologia que tornaram nossos dias mais fáceis. Por ter interagido mais diretamente, agradeço especialmente a Maielli, a Ligiana, ao Álvaro e a Cida.

Aos meus grandes amigos André Fisher, Daltro Cella, Humberto Spolador, José Roberto Canziani, Mauro Osaki, Robson Mafioletti e Sérgio, por todos os bons momentos na república.

Ao corpo de funcionários da Mezzo Assessoria e Planejamento, como os grandes amigos Mauro Catharino Vieira da Luz e Antônio Carlos Pinheiro dos Santos, pelas discussões sobre o setor. Pelo mesmo motivo agradeço aos funcionários da Fenavist, que contribuíram diretamente para aprofundar meu conhecimento, como a superintendente Rosângela Menezes e as companheiras Débora Oliveira e Evana Elídia.

A todos amigos da ESALQ que estiveram envolvidos em meus momentos de alegrias e angustia.

A CAPES por ter financiado parte de minha pós-graduação.

A vida, pela família que tenho. 
Página

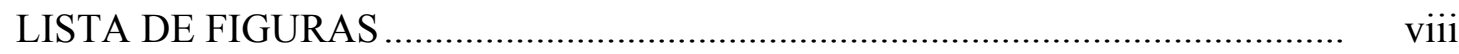

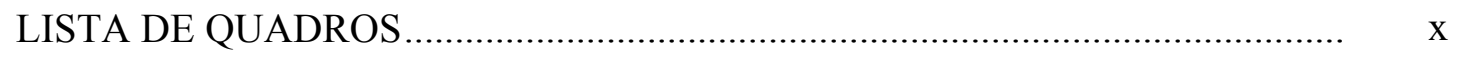

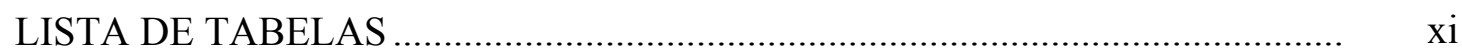

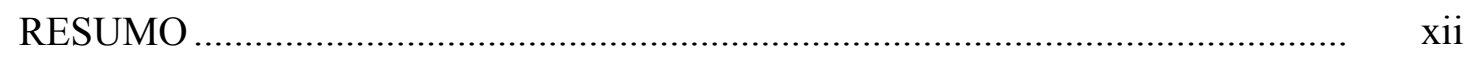

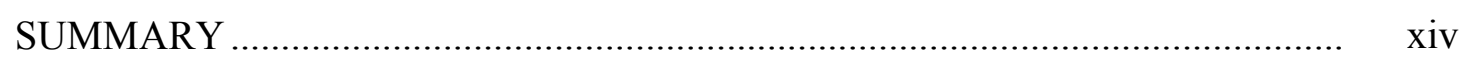

1 INTRODUÇÃO ...................................................................................... 1

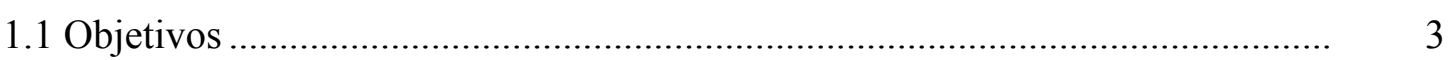

1.2 Justificativas do estudo ............................................................................ 4

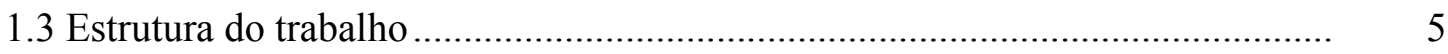

2 A SEGURANÇA PRIVADA NO BRASIL ........................................................ 6

2.1 Características gerais de sistemas de segurança.................................................. 6

2.2 A segurança eletrônica ................................................................................... 8

2.3 Caracterização do contexto social e econômico da segurança privada ............... 10

2.3.1 Estudos empíricos da segurança privada no Brasil ......................................... 10

2.3.2 $\mathrm{O}$ mercado de trabalho de segurança privada .................................................. 10

2.3.2.1 Características dos vigilantes .................................................................... 13

2.3.2.2 Características dos empregos gerados no setor de vigilância privada .......... 14

2.3.2.3 Grau de instrução dos vigilantes .................................................................. 16

2.3.2.4 Remuneração dos trabalhadores............................................................... 20

2.3.5 Outras remunerações e despesas .................................................................... 26 
2.3.6 Tributos

2.3.7 Distribuição geográfica dos serviços .............................................................. 28

2.3.8 A segurança privada nos grandes centros urbanos........................................ $\quad 30$

2.3.9 Regulamentação da atividade........................................................................ 31

3 REVISÃO DE LITERATURA …................................................................ 33

3.1 Nova Economia Institucional - aspectos gerais............................................. 34

3.1 A Economia dos Custos de Transação ............................................................... 38

3.1.2 Atributos das transações............................................................................... 40

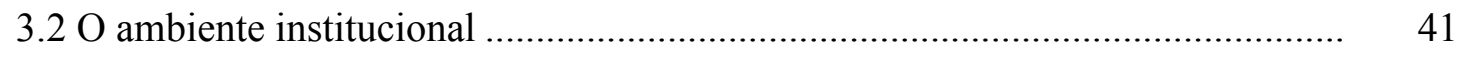

3.2.1 Direitos de propriedade .............................................................................. 42

3.2.1.1 Externalidades ...................................................................................... 43

3.2.1.2 Bens públicos, quase públicos e privados ................................................... 44

3.2.1.2.1 Serviços de segurança ............................................................................ 46

3.2.1.2.2 Espaços comunais ................................................................................... 47

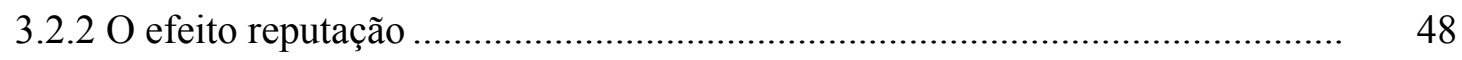

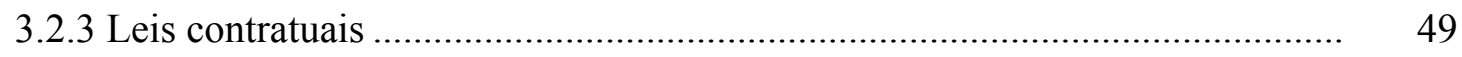

3.3 Estruturas de governança ............................................................................... 50

$3.4 \mathrm{O}$ problema da assimetria de informações no mercado de trabalho.................... 52

3.5 Salário de eficiência e incentivos ...................................................................... 57

3.6 A expansão da segurança privada ................................................................... 63

3.7 A reformulação do policiamento público........................................................... 65

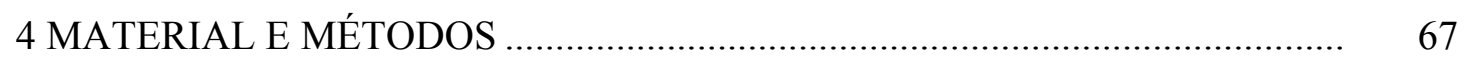

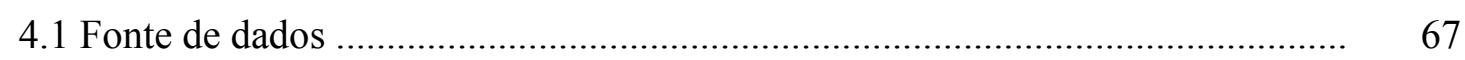

4.2 Procedimento de aplicação do questionário ....................................................... 67

4.3 Análise de Correspondência............................................................................ 69

4.4 Análise de Conglomerados ......................................................................... 74

5 RESULTADOS DA PESQUISA EMPÍRICA SOBRE A ATIVIDADE DE SEGURANÇA PATRIMONIAL PRIVADA ....................................................... 76

5.1 Estruturas de governança na prestação de serviços de vigilância patrimonial privada 
5.2 O mercado de prestação de serviços de vigilância irregular ................................ 77

5.3 Atividade regular de segurança privada ........................................................... 82

5.3.1 Contratação de vigilantes para uso próprio (serviços orgânicos)..................... 82

5.3.2 Contratação de empresas de segurança privada ............................................... 84

5.3.2.1 Monitoramento do trabalhador............................................................... $\quad 92$

5.3.2.2 Remuneração de trabalhadores e eficiência ................................................ 94

5.3.2.3 Promoção da qualidade dos serviços............................................................. 97

5.3.2.4 Recrutamento e admissão........................................................................... 100

5.3.2.5 Desligamento de trabalhadores ................................................................ 103

5.3.2.6 Análise de correspondência e de cluster aplicadas à análise de resultados... $\quad 105$

6 CONCLUSÕES ...................................................................................... 111

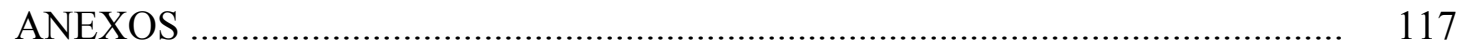

REFERÊNCIAS BIBLIOGRÁFICAS …………........................................... 127 


\section{LISTA DE FIGURAS}

Página

1 Componentes de sistemas de segurança privada....................................................

2 Pessoal ocupado em serviços de investigação, vigilância e segurança (em milhares).

3 Número total de vigilantes em atividade em empresas de segurança privada (em milhares)

4 Evolução do grau de instrução dos vigilantes (em milhares).

5 Percentagem acumulada do total de vigilantes em atividade em empresas de segurança privada, por faixa salarial (R\$1.000,00) no Brasil, 2001

6 Evolução da remuneração média anual de pessoal ocupado no setor de segurança privada e no setor de serviços não financeiros, de 1998 à 2001 (em R\$ milhares) ..

7 Participação das principais faixas salariais no rendimento de vigilantes no

Brasil, em 2001 (em \%)

8 Tributos pagos pelas empresas no setor de segurança privada e pelo setor de serviços não-financeiros no Brasil (em R \$ milhões)

9 Distribuição Regional da Receita Bruta dos Serviços de Investigação, Vigilância, Segurança e Transporte de Valores no Brasil, 2001 (em mil R\$).

10 Esquema de três níveis 
11 Custos de governança de transações de arranjos institucionais distintos em função da especificidade de ativos

12 Distribuição de probabilidades dos valores dos trabalhadores

13 Probabilidade ótima de fraude $\left(p^{*}\right)$

14 Distribuição das empresas de segurança patrimonial na cidade de São Paulo ....

15 Representação esquemática da transação no mercado clandestino de prestação de serviços

16 Representação dos serviços de vigilância constituídos por empresas clandestinas

17 Representação dos serviços de segurança privada contratados para uso próprio

18 Número de respostas por categoria, indicando os fatores que estimulam clientes a contratarem os serviços da empresa

19 Número de respostas por categoria, indicando o quão costumeira é a contratação de serviços com preços superiores aos praticados no mercado

20 Número de respostas por categoria, indicando o efeito da baixa substituição de trabalhadores na melhoria da reputação da empresa

21 Número de respostas por categoria, dos tipos de cliente que comumente pedem a substituição de trabalhadores nos postos de vigilância

22 Representação da prestação de serviços por empresas regulares

23 Número de respostas por categoria, do impacto da remuneração sobre a supervisão, a eficiência e a rotatividade de trabalhadores

24 Número de respostas por categoria, sobre a vinculação entre clientes e trabalhadores 
25 Número de respostas por categoria, da influência das avaliações sobre a remuneração de trabalhadores....

26 Número de respostas por categoria, dos fatores que influenciam na diferenciação das remunerações de trabalhadores

27 Número de respostas por categoria, dos fatores que influenciam na promoção da qualidade dos serviços.

28 Número de respostas por categoria, dos fatores que influenciam na redução da rotatividade dos trabalhadores

29 Número de respostas por categoria, dos danos provocados pela rotatividade de trabalhadores

30 Número de respostas por categoria, dos fatores que influenciam na contratação de trabalhadores

31 Número de respostas por categoria, sobre a importância da filtragem de trabalhadores em processo seletivos

32 Número de respostas por categoria, sobre a freqüência de utilização de meios de contratação

33 Número de respostas por categoria, sobre causas de desligamentos de trabalhadores

34 Plano fatorial relacionando variáveis e observações.

35 Número de clusters pelo método de Ward 


\section{LISTA DE QUADROS}

Página

1 Características dos bens públicos e quase públicos .............................................. 45

2 Representação da análise de correspondência múltipla através da Tabela de Burt 71

3 Descrição de medidas de interpretação dos planos fatoriais .................................... $\quad 74$ 


\section{LISTA DE TABELAS}

Página

1 Distribuição do pessoal ocupado na atividade de vigilância e guarda, por tipos de ocupações, Brasil, 1993-2002

2 Evolução da distribuição do tempo de vínculo de vigilantes em empresa de segurança privada (em \%)

3 Rotatividade da mão de obra por ano de escolaridade (\%), 1995 a 2001

4 Distribuição de vigilantes admitidos e desligados por faixa salarial, 1999 e 2001, Brasil (em \%)

5 Decomposição da Inércia e teste Qui-quadrado 


\title{
EMPRESAS DE VIGILÂNCIA NO SISTEMA DE PRESTAÇÃO DE SERVIÇOS DE SEGURANÇA PATRIMONIAL PRIVADA
}

\author{
Autor: ARYEVERTON FORTES DE OLIVEIRA \\ Orientadora: Prof ${ }^{\mathrm{a}} \mathrm{Dr}^{\mathrm{a}}$ HELOISA LEE BURNQUIST
}

\section{RESUMO}

O principal objetivo desta tese foi identificar como empresas de vigilância patrimonial privada legalmente constituídas participam do sistema de prestação de serviços de segurança, estabelecendo mecanismos de incentivo, controle, treinamento e busca de informações para a promoção da qualidade dos serviços. A importância do estudo surge da necessidade de averiguar se empresas de vigilância, reguladas e fiscalizadas, podem promover a eficiência no sistema de prestação de serviços. Foram coletados dados secundários sobre o setor e, com base nos fundamentos teóricos da Nova Economia Institucional (NEI), foi aplicado questionário à amostra aleatória de empresas de segurança patrimonial na cidade de São Paulo. Essas informações foram analisadas com maior profundidade por meio de dois métodos multivariados, análise de correspondência e de conglomerados, para obter o perfil da segurança privada em São Paulo a partir do agrupamento das empresas com características semelhantes. Detectouse que a presença de assimetria de informações leva ao emprego de processos de filtragem, identificação de sinais de qualidade emitidos pelos trabalhadores, e a 
utilização de incentivos e monitoramento para assegurar o comportamento adequado. De maneira geral, houve distinção clara entre empresas que atendem o setor público, priorizando mais o preço que a qualidade dos serviços, e as que atendem clientes do setor privado, em que fatores de qualidade podem permitir a cobrança de preços maiores para os serviços. Embora a remuneração do vigilante aparenta ser superior à de ocupações alternativas no mercado, empresas diferiram na prática de remunerações, seguindo o interesse do contratante de serviços em pagar ou não pelo diferencial de qualidade. A idéia de salário de eficiência pode funcionar para algumas circunstâncias, mas a função de monitoramento do trabalhador é mantida intensa. A promoção da qualidade nesta forma de governança híbrida incluiria um esforço de controle sobre o trabalhador por parte do prestador de serviços, que confere menor capacidade adaptativa ao contratante sobre as atividades do vigilante. Conclui-se que a forma híbrida de governança, com a contratação da empresa de vigilância, pode promove a qualidade dos serviços ao garantir que pré-requisitos legais sejam respeitados na contratação, o treinamento e a reciclagem sejam oferecidos, os trabalhadores sejam selecionados e monitorados e a estrutura de incentivos via remunerações maiores que alternativas de mercado seja estabelecida. Contudo, verificou-se comportamentos particulares que impedem a generalização deste resultado para todos os casos, especialmente no caso de contratantes preferirem menores preços à maior qualidade, como contratantes do setor público. 


\section{FIRMS IN THE SECURITY SYSTEM SERVICES OF PRIVATE PROPERTY: AN EVALUATION OF ITS GOVERNANCE STRUCTURE}

Author: ARYEVERTON FORTES DE OLIVEIRA

Adviser: Prof ${ }^{a}$ Dr $^{a}$ HELOISA LEE BURNQUIST

\section{SUMMARY}

The main objective of this thesis was to identify how firms in the security system services for private properties, which are legally constituted, participate of the security system services, establishing mechanisms for incentive, control and training of their employees, besides searching for information to promote the quality of its services. The importance of the study is related to the need to evaluate if monitoring firms, regulated and fiscalized, can promote efficiency in the service sector. Secondary data about the sector was collected and a questionnaire, based on the theoretical fundaments of the New Institutional Economics (NIE), was applied to a random sample of companies that provide security services for private properties in the city of Sao Paulo. This information was analyzed through two multivariate methods, analysis of correspondence and of conglomerates, to obtain a profile of the private insurance in Sao Paulo, based on a group of companies with similar characteristics. The study results indicated that information asymmetry lead to the employment of filtering, identification of the quality 
signs of the workers and the use of incentive for monitoring and assuring adequate behavior. In general, there was a clear distinction between the companies that provided services to the public sector and those that provide services for the private sector. The former seemed to prioritize prices instead of quality of the services, while the later could charge higher prices for high quality services. Although the remuneration of the security officer seems to be higher than those in other activities, companies differ with respect to remuneration, according to the interest of the customers in paying for differentiated services. The efficiency wage idea can work in some circumstances although the function of monitoring the worker is intense. Quality promotion in this form of hybrid governance includes efforts to control the employee by the service provider, improving the service quality as it guarantees legal requisites are in the contract that confers less adaptive capacity to the contractor over the activities of the security officers. It can be concluded that a hybrid governance, contracting the security firm, com promote service quality guaranteeing that legal pre-requisites are respected in hiring, training and recycling be provided, personnel be selected and monitored and the incentives above market value be established. However, specific behavior that prevent the generalization of these results for all cases was observed, specially in case where contractors preferred lower prices to higher quality, as in public sector contractors. 


\section{INTRODUÇÃO}

Este estudo trata de mecanismos de incentivo e controle estabelecidos por empresas de vigilância, devidamente regulamentadas, em transações realizadas no sistema de prestação de serviços de segurança privada. O maior entendimento das estruturas de governança de transações, especialmente a que envolve a prestação de serviços terceirizados, pode revelar estratégias importantes para o desenvolvimento da atividade regulamentada e abrir caminho para a compreensão da interação entre o ambiente institucional e a cadeia de prestação de serviços. O trabalho visa apresentar subsídios que auxiliem a compreensão de diferenças no comportamento de empresas prestadoras de serviços e diferenças entre atividades regulamentadas e clandestinas.

A análise considera a assimetria de informações como causa fundamental de ineficiências no sistema de prestação de serviços, particularmente por prejudicar a condução de transações via mercado de trabalho e por prejudicar o monitoramento de trabalhadores no exercício de suas funções. Considera-se importante, portanto, a investigação dos mecanismos utilizados pelas empresas para minimizar os danos que possam vir a ser causados pela assimetria de informações, particularmente no que se relaciona ao emprego de trabalhadores e à promoção da qualidade dos serviços. $\mathrm{O}$ foco na assimetria de informações como causa de falhas do mercado advém do fato de serem alguns dos atributos dos trabalhadores, como honestidade e atenção, por exemplo, não diretamente observáveis mesmo depois de contratá-los, tornando custoso o problema da assimetria de informações.

A demanda por serviços privados de segurança ocorre, geralmente, quando esses se tornam necessários para preservar direitos de propriedade, uma instituição fundamental para a existência de incentivos à realização de investimentos e transações. O crescimento recente dos serviços de vigilância é interpretado, no presente estudo, 
como uma reação à crescente limitação dos serviços públicos em cuidar principalmente dos aspectos preventivos da segurança, acompanhando de perto o desenvolvimento de novas formas de organização de espaços coletivos como sugerem Kempa et al. (2004)

Autores como Bayley e Shearing (2001) indicam que na história da humanidade somente a cerca de duzentos anos os serviços de policiamento público passaram a dominar a prestação de serviços privados. No entanto, mais recentemente a segurança privada ressurgiu e possibilitou o desenvolvimento de mecanismos de controle de acesso, monitoramento e proteção contra crimes, que vinculados com novas formas de organização de espaços comunais sob propriedade privada, tornam-se atraentes para a interação humana nas sociedades modernas.

A análise do sistema de prestação de serviços de segurança, desenvolvida no presente trabalho, visa auxiliar a identificação da maneira pela qual as estruturas de governança e o ambiente institucional coordenam as transações realizadas no sistema de prestação de serviços de segurança. No entanto, o estudo não traz uma avaliação das implicações das novas formas de gestão da segurança sobre questões de equidade e acesso aos serviços, que vêm sendo há bastante tempo buscados pelo policiamento público. Busca-se compreender qual é a natureza da inter-relação entre os setores público e privado, visando a interação mais eficiente entre Estado, empregando a força nos confrontos com criminosos, e iniciativa privada, cuja ação preventiva é peculiar.

No que se refere ao o setor privado, o estudo visa averiguar se incentivos e mecanismos de monitoramento do comportamento dos vigilantes são estabelecidos para coordenar a prestação de serviços, inibindo o oportunismo dos indivíduos. A demanda por vigilantes pode ser atendida através da contratação direta de trabalhadores ou da terceirização. Políticas públicas podem incorporar esses aspectos na definição dos mecanismos de regulação, especificamente, sobre a legislação e a fiscalização do setor e sobre as iniciativas privadas de sinalização para demandantes das características individuais dos prestadores de serviços.

Ao relacionar a assimetria de informações ao mercado de trabalho, este sofreria com um racionamento de bons trabalhadores, que por, sua vez, levaria ao ressurgimento de dois mecanismos importantes para o estabelecimento de transações: a sinalização e a 
seleção de trabalhadores. Adequar trabalhadores aos postos de vigilância, de acordo com atributos requeridos, seria a principal função econômica das empresas, quando a emprega goza de boa reputação perante clientes e trabalhadores.

Paralelamente, o estudo visa aumentar a compreensão de problemas de emprego informal e da alta rotatividade da mão-de-obra, típicos do setor, que prejudicam trabalhadores, clientes e empresas prestadoras de serviços. Os trabalhadores preferem uma baixa rotatividade pelo risco de permanecerem desempregados ou não conseguirem uma colocação equivalente ou melhor no futuro, principalmente se não houver uma maneira de se diferenciarem dos demais. Do ponto de vista dos empresários, a alta rotatividade geralmente implica em altos custos envolvidos em processos de seleção e de rescisão de contratos, além de uma perda de capital humano treinado segundo os interesses de clientes.

\subsection{Objetivos}

O objetivo geral do estudo está em identificar como empresas privadas legalmente constituídas participam do sistema de prestação de serviços de segurança, estabelecendo como mecanismos de incentivo e controle promovem a qualidade dos serviços prestados. A principal hipótese do trabalho é que as empresas de vigilância utilizam ativamente instrumentos para monitorar a aptidão dos indivíduos e descobrir informações privadas, formando uma estrutura híbrida de governança que permite a redução de custos de transação.

Como objetivos específicos do estudo estabelecem-se:

1. Determinar como podem ser interpretadas as interações dos agentes no sistema de prestação de serviços de segurança patrimonial privada, quando prevalece a assimetria de informações, distinguindo prestadores de serviços que atuam em regularidade ou não;

2. Verificar se os mecanismos de sinalização, seleção, salário de eficiência e monitoramento são utilizados na promoção da prestação de serviços de segurança patrimonial por empresas que atuam dentro da legalidade; 
3. Agrupar empresas para identificar quais as características que levam ao uso diferenciado dos mecanismos mencionados no item 2, afetando o gerenciamento dos recursos humanos.

\subsection{Justificativas do estudo}

A dificuldade em identificar, junto à literatura nacional, trabalhos que sistematizem a prestação de serviços de segurança reitera a importância da condução do estudo. Os problemas causados pelo aumento da criminalidade e da insegurança, além da redução da oferta de serviços públicos para a defesa de propriedades, resultam na criação de demandas para a formulação de planos para a promoção da segurança que integram informações dos serviços público e privado.

A conveniência do estudo também está em questionar a visão geral que divide segurança provida pelo Estado e pelo setor privado. Espaços de propriedade privada freqüentados pelo público são controlados por sistemas de segurança privados, que impedem e monitoram o acesso e trabalham pela redução de oportunidades de agressões às propriedades privadas, empregando recursos humanos, equipamentos e instalações de maneira complementar ou substitutiva em função das características da propriedade defendida e da liberdade de acesso autorizada pelo detentor da propriedade privada. $\mathrm{O}$ uso legítimo da força para conter agressões, perseguir e capturar agressores continua sendo conferido ao aparato de segurança pública sob a restrição de procedimentos para limitar abusos no uso da força.

A importância do estudo surge da necessidade de averiguar como empresas de segurança privada, reguladas e fiscalizadas, podem promover a eficiência no sistema de prestação de serviços. O intuito do trabalho é, em parte, desenvolver um contexto analítico que possibilite a análise e compreensão da forma pela qual a terceirização expandiu-se, criando bases para analisar a eficiência das empresas que administram recursos humanos com especificidade de ativos menor e tarefas de pequena complexidade, como também são os serviços de limpeza e conservação e de portaria.

Oportunidades de aplicações da análise em outras áreas podem surgir, com adaptações para análise de terceirização em serviços de engenharia, consultoria contábil 
e administrativa e de tecnologia da informação, embora com maior dificuldade pela maior complexidade nos serviços prestados e a especificidade de ativos. contudo, é importante ressaltar que em trabalhos aplicados, procure-se identificar como tais firmas poderiam minimizar custos de transação.

\subsection{Estrutura do trabalho}

Esta tese está estruturada em seis capítulos. além dessa introdução, na qual são apresentados os objetivos e justificativas do estudo; o segundo capítulo apresenta uma descrição do papel da segurança privada no Brasil; um terceiro capítulo relaciona a segurança privada com os desenvolvimentos teóricos da Nova Economia Institucional, abordando as questões de falhas do mercado na presença de bens públicos e externalidades, de maneira secundária, e a questão de criação de mecanismos de incentivo e controle na presença da assimetria de informações, a principal causa de falha de mercado de interesse neste estudo; o quarto capítulo descreve os dados primários e secundários e propõe análise multivariada para consolidar as informações obtidas na pesquisa de campo; o quinto capítulo, no qual são expostas análises dos resultados e discussões; e, finalmente, no sexto são apresentadas as principais conclusões deste trabalho. 


\section{A SEGURANÇA PRIVADA NO BRASIL}

Um estudo da atividade de segurança privada compreende uma caracterização de seu contexto social e econômico. Este capítulo apresenta a revisão de trabalhos aplicados empregados para determinação dos referenciais teóricos que permitem avaliar e compreender as relações entre prestadores, reguladores e os consumidores de serviços de segurança privada no Brasil. O estudo do sistema de prestação de serviços, em termos das estruturas de governança e das instituições em torno das transações econômicas, passa pelo desenvolvimento dos conceitos e relações econômicas aqui apresentados.

\subsection{Características gerais de sistemas de segurança}

Serviços de segurança privada incluem, de maneira geral, instalações e barreiras físicas, equipamentos e recursos humanos para a defesa do patrimônio e dos interesses de proprietários, seguindo as normas e procedimentos por eles estabelecidos e dentro dos limites de seu direito de propriedade. Um sistema de segurança privadamente organizado tem por funcionalidade restringir, controlar e monitorar acessos a pessoas e patrimônios, em possível conexão com o sistema público que, com legitimidade, pode empregar a força no aprisionamento e perseguição de agressores de propriedades e indivíduos.

Além do policiamento público, como mostra a Figura 1, os recursos humanos contratados direta ou indiretamente pelos sistemas privados envolvem-se principalmente na prevenção e investigação de crimes contra patrimônios e pessoas. $\mathrm{O}$ policiamento público atuaria principalmente nas ocorrências em que o uso da força faz-se necessário, ou em situações em que o registro de crimes implica a investigação policial. 


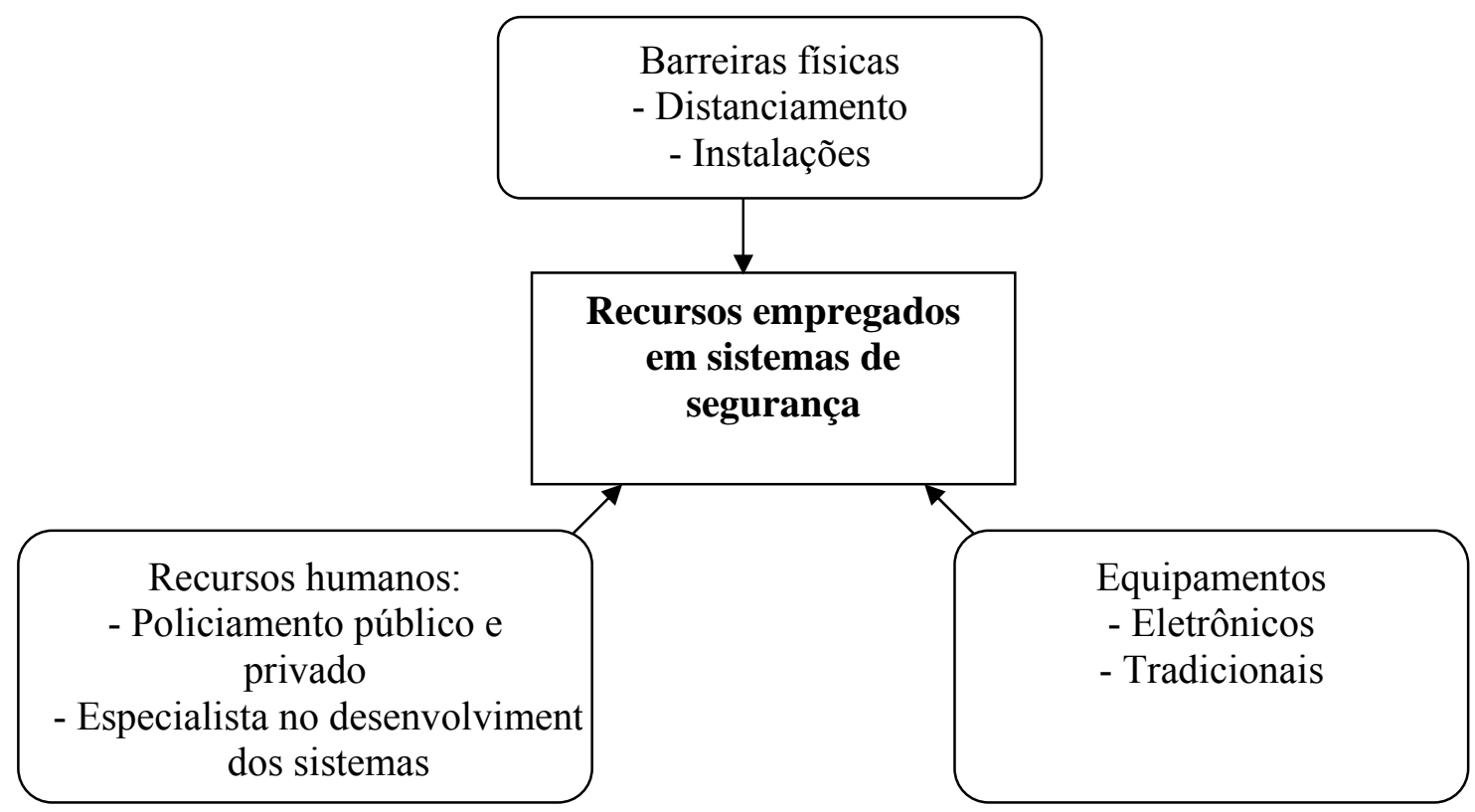

Figura 1 - Componentes de sistemas de segurança privada

Uma característica do funcionamento do sistema que merece ser destacada, constitui-se no o impedimento e o controle de acesso às propriedades. As barreiras físicas geralmente são as principais responsáveis pelo impedimento de acesso às propriedades, podendo ser sua efetividade aumentada com sistemas eletrônicos de detecção de invasões e com emprego de vigilantes. O impedimento ao acesso pode ser requerido tanto para a segurança de propriedades do Estado quanto da iniciativa privada, residências ou unidades de produção industrial, ou temporariamente, como lojas em horários não comerciais.

Estabelecidas as barreiras físicas, cabe ao sistema de segurança cuidar de um segundo aspecto funcional, que se constitui no controle de pontos de acesso e monitoramento dos fluxos de pessoas. Agências bancárias e outros estabelecimentos financeiros, shoppings centers, grandes lojas de departamentos e supermercados são exemplos de locais onde a restrição de acesso perde espaço para as funções de 
monitoramento e controle, dada a intensidade das interações necessárias com o público, em função da natureza dos serviços prestados por essas entidades ou instituições. Além do emprego de recursos humanos e barreiras físicas, equipamentos também vêm sendo intensivamente empregados na constituição dos sistemas de segurança.

À medida que o bloqueio de acesso pode ser amplamente utilizado, como em prédios, condomínios e clubes, o uso de equipamentos e recursos humanos para as funções de monitoramento e controle de ações tende a ser menos intenso. $O$ desenvolvimento da tecnologia eletrônica, no entanto, marcou uma revolução nos custos de monitoramento nos sistemas, tornando viável o desenvolvimento de espaços em que a restrição de acesso pode ser amenizada. Em espaços privados com intensa visitação é maior o emprego de um sistema moderno de monitoramento que, embora diminua a necessidade de mão-de-obra para uma tarefa específica, acaba viabilizando sistemas mais eficazes e ampliando sua utilização. À medida que o julgamento de ocorrências passa pelo crivo de um trabalhador, o emprego da mão-de-obra pode ser intensificado com a ampliação de novas formas de propriedade que disponibilizam espaços comunais.

A difusão de shoppings centers, condomínios industriais, residenciais e comerciais configura a expansão de novas formas de propriedade privada que estabelecem um sistema de segurança para uso coletivo. O controle de ambientes pelo policiamento privado, seguindo normas e procedimentos ajustáveis aos interesses dos clientes por um corpo administrativo, cria um ambiente favorável à adaptação de um sistema de segurança para intervenção efetiva sobre a prevenção de delitos, sendo as capacidades de reação e de adaptação críticas, o que tornam os serviços públicos, neste sentido, bem menos eficientes. O policiamento produzido pelo Estado segue normas e procedimentos rígidos destinando-se mais aos aspectos reativos que preventivos de segurança.

\subsection{A segurança eletrônica}

Conforme Cubas (2002), a expansão da segurança eletrônica é beneficiada tanto pelo barateamento dos equipamentos quanto pela intensa evolução tecnológica neste tipo de serviço. O impacto que os sistemas de comunicação e equipamentos modernos 
provocam no emprego de vigilantes, no entanto, pode não ser tão intenso quanto em outras atividades. A substituição de homens por máquinas pode ser limitada pela necessidade de interação com visitantes e julgamento de ocorrências por trabalhadores. Ao analisar dados da Pesquisa Anual de Serviços, segundo Estudo do setor de segurança privada (2004), a razão entre receita operacional líquida e pessoal ocupado - um indicador da produtividade setorial - cresce mais lentamente na segurança privada $(6 \%$ em 2000 e 4\% em 2001) que no agregado do setor de serviços não-financeiros (10\% e $11 \%$ para 2000 e 2001), indicando uma substituição menos agressiva de homens por máquinas nessa atividade específica, relativamente ao total de serviços. Ao viabilizar o emprego de sistemas de monitoramento em lugar de restrições de acesso, a segurança eletrônica pode promover eficiência na vigilância sem implicar dispensa de empregados tão intensa quanto em outras atividades.

Os órgãos que fiscalizam as atividades de empresas de segurança eletrônica devem atestar que essas não empregam vigilantes sem a habilitação e o cumprimento de normas estabelecidas pela lei n. 7.102/83 e atos normativos. Cabe às Delegacias Regionais do Trabalho fiscalizarem o cumprimento das normas trabalhistas pelos profissionais dessas empresas.

Uma série de recursos pode ser utilizada na segurança eletrônica, mas todos devem ser integrados ao sistema físico ou ao corpo de vigilância. Uma forma mais elaborada de utilização de recursos eletrônicos seria o sistema de monitoramento integrado com centrais capazes de acionar unidades de vigilância, polícia, ambulância ou bombeiros para dirigirem-se com agilidade aos a locais de ocorrências.

Dentre insumos utilizados nos sistemas modernos de segurança eletrônica estariam os sistemas de circuitos fechados de televisão (CFTV); sistemas de controle de acesso através de abertura e fechamento de portas; sistemas automáticos de iluminação; sistema de detecção de invasões e roubos (com a detecção de movimentos por infravermelhos, variações de luminosidade, impactos, mudanças em campos magnéticos, sonoros, de calor, barreiras de microondas) 


\subsection{Caracterização do contexto social e econômico da segurança privada}

Serviços de segurança configuram despesas indiretas para os contratantes, ou seja, geralmente podem ser caracterizados como um insumo que participa indiretamente dos processos de produção de bens e serviços, sem deixar, no entanto, de ser crucial. Sua importância está em garantir o respeito aos direitos de propriedade privada adquiridos, sustentando as relações econômicas entre os agentes.

\subsubsection{Estudos empíricos da segurança privada no Brasil}

O trabalho de Cubas (2002) analisa os principais determinantes da expansão das empresas na cidade de São Paulo. A autora aponta o aumento da criminalidade, do medo e a incapacidade do Estado em resolver conflitos como os principais responsáveis pela expansão dos serviços privados. Sua revisão da literatura apresenta uma profunda discussão sobre o condicionamento da relação entre Estado e sociedade no Brasil para uma defesa de interesses particulares com recursos públicos e privados. Seus argumentos, inspirados pelo trabalho de Christie (1998), apontaram que a estrutura familiar estabelece na sociedade uma defesa de interesses particulares em detrimento de interesses coletivos, e que o enfraquecimento da autoridade policial estaria levando ao emprego de recursos privados em moldes observados ao anterior surgimento do Estado moderno, detentor do monopólio da violência e responsável por estabelecer uma estrutura organizacional capaz de firmar autoridade, controle e cumprimento da lei.

Para Paixão (1991), o crescimento da segurança privada resultou da maior complexidade da organização policial, que cria uma série de procedimentos burocráticos e faz uso recorrente da força como um meio de controle, ao invés do consenso, reduzindo o apoio das comunidades ao seu trabalho.

\subsubsection{O mercado de trabalho de segurança privada}

Conforme Estudo do setor de segurança privada (2004), o setor de segurança contribui bastante para a geração de empregos no Brasil. De acordo com o Departamento de Polícia Federal (DPF), citado nesse trabalho, no ano de 2003 encontravam-se em atividade cerca de 348,5 mil vigilantes em 2100 empresas de 
vigilância e transporte de valores. Tais números correspondem a uma média de 166 vigilantes por empresa, aos quais podem ser somados um corpo de funcionários administrativos, de cerca de $10 \%$ dos vigilantes, o que eleva a média para cerca de 184 empregados por empresa.

Os dados de empregos formais são confirmados pela da Pesquisa Anual de Serviços (PAS) do IBGE, para os anos de 1998 a 2001. Tomando empresas com 20 ou mais empregados, um subconjunto que excluí grande parte das empresas de investigação na atividade de investigação, segurança e transporte de valores, calculou-se uma média de 383 empregados por empresa em 2001, muito superior à média verificada no agregado de serviços não-financeiros, de 7,7 empregados, e a média verificada no agrupamento de serviços prestados às empresas (atividades terceirizadas) de 13,2 empregados. A Figura 2 apresenta a evolução do pessoal ocupado em serviços de investigação, vigilância e segurança, nos anos de 1999 a 2001.

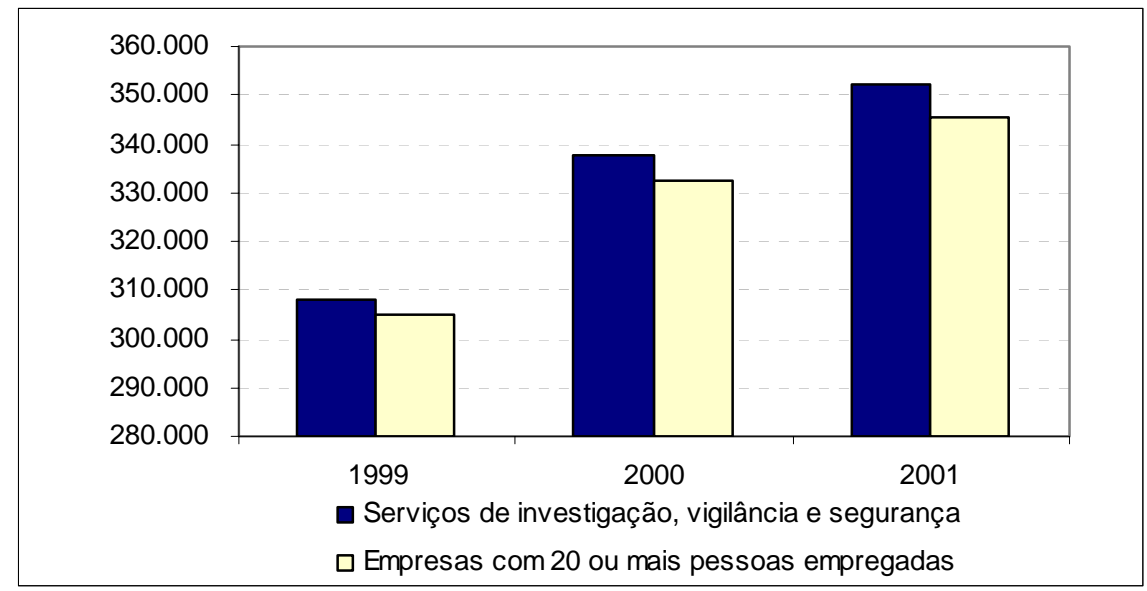

Figura 2 - Pessoal ocupado em serviços de investigação, vigilância e segurança (em milhares)

Fonte: elaborado a partir de IBGE (1999 - 2001)

Em 2001, a atividade de investigação e segurança privada empregava cerca de $5,5 \%$ do pessoal ocupado no setor de serviços não-financeiros e aproximadamente $17,3 \%$ nos serviços prestados às empresas. Como observado em Estudo do setor de segurança privada (2004), a participação da segurança privada nos serviços não- 
financeiros, em termos de empregados, é mais que o dobro da participação em termos de receita operacional líquida. Isto significa que para o volume de recursos apropriados, as empresas de segurança privada estariam garantindo mais postos de trabalho que a grande maioria das outras atividades de serviços não-financeiros.

A análise da distribuição das ocupações do pessoal nas empresas da atividade de vigilância e guarda, com base nos dados da Pesquisa Nacional por Amostra de Domicílios (PNAD), considerando apenas prestadores formais de serviços, de maneira semelhante à avaliação apresentada por Musumeci (1998), permite verificar que no período de 1993 a 2002 ocorreram algumas oscilações nas somas das ocupações de vigias e vigilantes dentre as demais funções exercidas (Tabela 1)., A representatividade relativa das funções ilustradas na figura 1 mantêm-se, no entanto, próxima de $83 \mathrm{em}$ relação ao total, tanto no início, quanto ao final do intervalo.

Tabela 1. Distribuição do pessoal ocupado na atividade de vigilância e guarda, por tipos de ocupações, Brasil, 1993-2002

\begin{tabular}{lrrrrrrrr}
\hline & \multicolumn{7}{c}{ \% pessoal ocupado } \\
\cline { 2 - 9 } \multicolumn{1}{c}{ Descrição } & 1993 & 1995 & 1996 & 1997 & 1998 & 1999 & 2001 & 2002 \\
\hline Auxiliar administrativo & 1,61 & 1,09 & 1,90 & 1,59 & 1,43 & 1,48 & 1,50 & 1,69 \\
Encarregado administ. & 2,20 & 1,93 & 2,06 & 1,77 & 1,00 & 1,68 & 1,39 & 1,28 \\
Motorista & 1,59 & 1,89 & 1,99 & 2,43 & 2,73 & 1,42 & 1,83 & 0,63 \\
Porteiro & 0,77 & 1,48 & 1,74 & 2,21 & 1,84 & 2,15 & 3,42 & - \\
Servente & 2,48 & 1,67 & 0,82 & 1,28 & 0,99 & 3,17 & 2,48 & 0,48 \\
Sócio/empregador & 0,55 & 1,36 & 1,10 & 0,14 & 1,19 & 0,61 & 1,07 & 1,06 \\
Vigia & 26,29 & 23,68 & 25,25 & 23,00 & 31,12 & 24,57 & 22,55 & 24,47 \\
Vigilante & 56,75 & 57,72 & 55,63 & 55,41 & 52,64 & 56,71 & 53,99 & 59,32 \\
Outros & 7,77 & 9,18 & 9,50 & 12,17 & 7,05 & 8,21 & 11,77 & 11,06 \\
Total & 100,00 & 100,00 & 100,00 & 100,00 & 100,00 & 100,00 & 100,00 & 100,00 \\
\hline
\end{tabular}

Fonte: IBGE (1993 - 2002)

Marcante na atividade é a clandestinidade, para a qual surgem números expressivos e dificilmente verificáveis, como de que haveria no Brasil mais de 900 mil vigilantes atuando de maneira irregular, segundo Estudo do setor de segurança privada 
(2004). Na clandestinidade estão também encontram-se policiais agindo fora do expediente, o que é proibido por lei, e como Musumeci (1998) aponta, costuma ocorrer um agenciamento ilegal dos trabalhadores por grupos organizados de vigilantismo dentro das próprias forças policiais, estimulada pela busca do segundo emprego para compensar quedas das remunerações de policiais. Segundo esse mesmo autor, a clandestinidade representa um risco para o próprio contratante se houver uso excessivo da força nas propriedades defendidas.

O trabalhado informal deteriora o padrão de concorrência e desfavorece trabalhadores e empresas do mercado. Os benefícios estabelecidos nas relações formais não são garantidos aos clandestinos, enquanto que trabalhadores formais têm suas remunerações atingidas pelo corte de custos das empresas na busca de competitividade. Para as empresas, a clandestinidade representa uma intensa redução de margens, que propaga o desrespeito às obrigações legais e atinge a qualidade dos serviços prestados. Cumprir a legislação implica aceitar uma série de procedimentos de autorização e licenciamento; recolher impostos e encargos; observar requisitos técnicos nas instalações e nos equipamentos; treinar e reciclar trabalhadores; cumprir termos de acordos coletivos, como pagamento respeitando os pisos salariais da categoria e horas extraordinárias de maneira diferenciada; realizar gastos em seleção e monitoramento de recursos humanos. A contratação de empresas clandestinas ocorre em função de preços competitivos obtidos com o desrespeito à regulamentação, mas parte ocorre pela desinformação dos contratantes de serviços sobre a situação do prestador perante órgãos de regulação, além das implicações de contratar empresas clandestinas.

\subsubsection{Características dos vigilantes}

Nota-se entre 1995 e 2001, 42,7\% dos vigilantes tinha entre 30 e 39 anos, seguido pelo contingente com idade entre 25 e 29 anos (25,9\%). No total, os dois grupos representavam 68,6\% dos vigilantes, segundo dados da Relação Anual de Informações sociais (RAIS). Estes dados são coerentes com a distribuição das idades apresentada por Musumeci (1998) a partir da PNAD, que chama a atenção da pequena participação de menores de idade e indivíduos com idade superior a cinqüenta anos. 
Um dado socioeconômico interessante é que na profissão de vigilante predomina a mão-de-obra do sexo masculino, como mostram os dados da RAIS de 1999 a 2001. Nesse período o contingente do sexo masculino era, em média, de 97\%, mas sendo registrado, no entanto, um aumento de participação de guardetes, vigilantes do sexo feminino. Musumeci (1998), baseado nos dados da PNAD/IBGE, afirmou que a atividade escapa dos tradicionais bolsões de subemprego domésticos e serviços pessoais, nos quais predominam a mão-de-obra feminina.

\subsubsection{Características dos empregos gerados no setor de vigilância privada}

A qualidade dos empregos é afetada pela rotatividade da mão-de-obra no setor, que medida como o mínimo entre admissões e demissões em um ano dividido pela mãode-obra empregada ao final do período, a partir de dados da RAIS/MTE, fica em torno de $25 \%$ da mão-de-obra. Gonzaga (2003) destaca que a rotatividade elevada da mão-deobra reduz investimentos em capital humano.

Segundo Estudo do setor de segurança privada (2004), a rotatividade tem origem em fatores distintos. Grande parte deveria ser atribuída a características de mercados regionais, que seriam em maior ou menor graus ocupados por contratantes de serviços do setor público. Os contratos com este cliente podem não ser renovados e implicar na demissão de trabalhadores em larga escala. De acordo com Estudo do setor de segurança privada (2004), há o interesse das empresas em evitar a geração de passivos trabalhistas, decorrentes de vínculos empregatícios prolongados, dificuldades de manutenção de contratos por longos períodos e de não demitir empregados quando de seu término. A influência da qualidade da mão-de-obra também foi apontada como uma causa da rotatividade, que motiva a investigação sobre a influência da assimetria de informações na prestação dos serviços.

A Figura 3 mostra que entre 1999 e 2001 as contratações passaram de 95,7 mil para 101,3 mil. Porém, 81,7\% dos admitidos em 1999 estavam na situação de reemprego e, em 2001, essa participação cresceu para 85,4\%. 


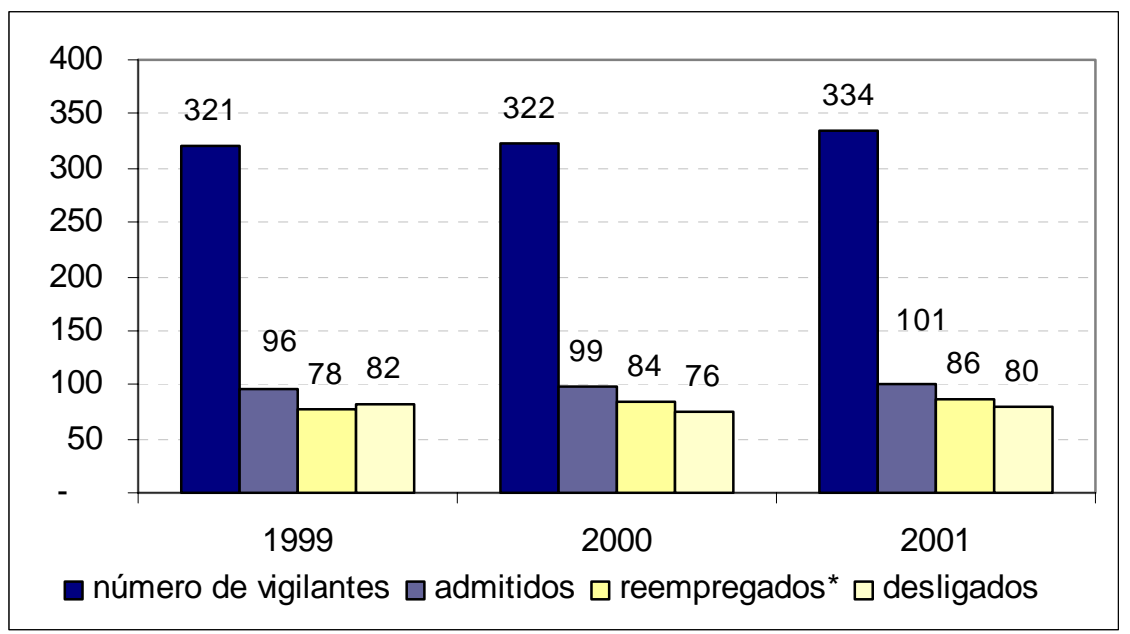

Figura 3 - Número total de vigilantes em atividade em empresas de segurança privada (em milhares)

Fonte: Brasil (1999-2001)

Para empresas de segurança privada os dados da RAIS/MTE mostram que demissões realizadas sem justa causa representaram cerca de $60 \%$ dos desligamentos ocorridos entre 1999 e 2001. O desligamento sem justa, causa por iniciativa do trabalhador, era o segundo motivo mais freqüente de desligamento (cerca de $17 \%$ ). Se for considerado que, em 2001, 45\% dos demitidos tinham até um ano de vínculo empregatício e $18 \%$ menos de três meses, fica claro o freqüente desinteresse de uma das partes em manter a relação após um curto período de convivência. O tempo de emprego entre 1999 e 2001 era de no máximo 1,9 ano para 54\% dos vigilantes e entre 2 e 4,9 anos para 30\%. Na média o tempo de serviços prestados a uma mesma empresa foi de 32 meses entre 1999 e 2001, como pode ser visto na Tabela 2, que mostra uma pequena elevação deste valor médio. 
Tabela 2. Evolução da distribuição do tempo de vínculo de vigilantes em empresa de segurança privada (em \%)

\begin{tabular}{lccc}
\hline Tempo (em meses) & 1999 & 2000 & 2001 \\
\hline Até 5,9 & 19,11 & 20,69 & 19,49 \\
de 6 até 11,9 & 15,38 & 14,31 & 15,22 \\
de 12 até 23,9 & 20,16 & 20,28 & 20,02 \\
de 24 até 35,9 & 14,32 & 12,98 & 13,03 \\
de 36 até 59,9 & 17,24 & 16,75 & 15,81 \\
Acima de 60 & 13,64 & 14,90 & 16,27 \\
Ignorado & 0,14 & 0,08 & 0,14 \\
Tempo médio total & 31,61 & 32,05 & 32,83 \\
\hline
\end{tabular}

Fonte: Brasil (1999-2001)

\subsubsection{Grau de instrução dos vigilantes}

As contratações de vigilantes com escolaridade superior à exigida por lei, equivalente à $4^{\mathrm{a}}$ série do ensino fundamental, têm acontecido com regularidade. Isto pode ser uma decorrência da migração de mão-de-obra de empregos que deixam de existir com a mudança tecnológica, na indústria e nos serviços, bem como da elevação da escolaridade média do brasileiro.

O mercado de trabalho de mão-de-obra semi-qualificada, em particular, enfrenta problemas com a assimetria de informações, como discutiu Camargo (2002). O desemprego da mão-de-obra no Brasil, segundo o autor, é maior entre os trabalhadores com escolaridade entre 5 e 12 anos de estudo, faixa de escolaridade a que pertence a maioria dos vigilantes na atividade formal. Segundo o autor, no momento da contratação os empregadores têm dificuldade de captar os atributos particulares de indivíduos, particularmente nos casos de escolaridade intermediária. Nessas circunstâncias, os atributos individuais seriam bastante diferentes, sendo o diploma secundário um sinal pouco claro da qualidade individual. Informações curriculares seriam bons indicadores para níveis educacionais altos ou baixos, pois nessas circunstâncias, poderia ser inferida uma produtividade alta ou baixa e uma remuneração adequada para o trabalhador poderia ser estabelecida. Este argumento justifica a inclusão no capítulo seguinte, de uma discussão da assimetria de informações no mercado de trabalho e dos problemas de 
sinalização e filtragem como parte importante da explicação da prestação de serviços de segurança privada.

Além de muitas vezes contratarem pessoas sem as características desejadas, os empregadores não têm meios para ajustar as remunerações e/ou os benefícios para manter os trabalhadores nos postos de trabalho, pela dificuldade de monitorar o desempenho individual, criando poucos incentivos para manter a relação de trabalho. Muitas empresas contratariam por tentativa e erro, identificando atributos durante um período de experiência, segundo Camargo (2002).

Este comportamento pode ser a chave para a compreensão da rotatividade e do subemprego informal Os dados da RAIS/MTE mostram que, boa parte dos desligamentos acontece sem justa causa, por iniciativa de empregados ou empregadores, com indivíduos com pouco tempo de emprego. Em 2001, 18\% dos demitidos tinham menos de três meses de emprego, 28\% tinham menos de seis meses e $45 \%$ menos de um ano. Algumas empresas melhoram a contratação de indivíduos com investimentos em processos de seleção, segundo Camargo (2002), mas os investimentos nesses departamentos seriam dispendiosos e com retorno bastante incerto.

A rotatividade da mão-de-obra também parece elevada para indivíduos com escolaridade intermediária, segundo informações da RAIS/MTE. em determinados anos, como 1995, 2000 e 2001, pode-se identificar uma relação direta entre a escolaridade e a rotatividade dos vigilantes, como mostra a Tabela 3. A medida de rotatividade (turnover) empregada é obtida, considerando-se o mínimo entre contratações e desligamentos dividido pelo pessoal empregado no último dia do ano de referência 
Tabela 3. Rotatividade da mão de obra por ano de escolaridade (\%), 1995 a 2001

\begin{tabular}{cccccccc}
\hline Ano & $\begin{array}{c}\text { Analfa- } \\
\text { beto }\end{array}$ & $\begin{array}{c}4^{\text {a }} \text { série } \\
\text { incom- } \\
\text { pleta }\end{array}$ & $\begin{array}{c}4^{\text {a }} \text { série } \\
\text { completa }\end{array}$ & $\begin{array}{c}8^{\text {a }} \text { série } \\
\text { incom- } \\
\text { pleta }\end{array}$ & $\begin{array}{c}8^{\text {a }} \text { série } \\
\text { completa }\end{array}$ & $\begin{array}{c}2^{\mathrm{o}} \text { grau } \\
\text { incom- } \\
\text { pleto }\end{array}$ & $\begin{array}{c}2^{\mathrm{o}} \text { grau } \\
\text { completo }\end{array}$ \\
\hline 1995 & $30 \%$ & $32 \%$ & $32 \%$ & $32 \%$ & $30 \%$ & $35 \%$ & $31 \%$ \\
1996 & $22 \%$ & $27 \%$ & $27 \%$ & $29 \%$ & $28 \%$ & $31 \%$ & $28 \%$ \\
1997 & $26 \%$ & $19 \%$ & $26 \%$ & $27 \%$ & $26 \%$ & $27 \%$ & $27 \%$ \\
1998 & $22 \%$ & $22 \%$ & $23 \%$ & $24 \%$ & $24 \%$ & $27 \%$ & $25 \%$ \\
1999 & $14 \%$ & $21 \%$ & $22 \%$ & $27 \%$ & $25 \%$ & $25 \%$ & $25 \%$ \\
2000 & $18 \%$ & $19 \%$ & $18 \%$ & $24 \%$ & $24 \%$ & $26 \%$ & $24 \%$ \\
2001 & $11 \%$ & $14 \%$ & $16 \%$ & $24 \%$ & $24 \%$ & $25 \%$ & $25 \%$ \\
\hline
\end{tabular}

Fonte: Brasil (1995 - 2001)

A rotatividade decresceu ao longo do tempo para todos os níveis de escolaridade, mas de maneira menos intensa para os níveis mais elevados. Essas reduções refletem um comportamento aparentemente pró-cíclico da rotatividade: o desaquecimento da econômia na segunda metade da década de 1990, em conjunção com transformações nas relações de emprego com as novas tecnologias e processos produtivos, tornaria os indivíduos menos propensos a deixar postos de trabalho. Como mostra a Figura 4, existe uma melhora do nível de escolaridade da mão-de-obra empregada, que não necessariamente implica maior estabilidade no emprego. 


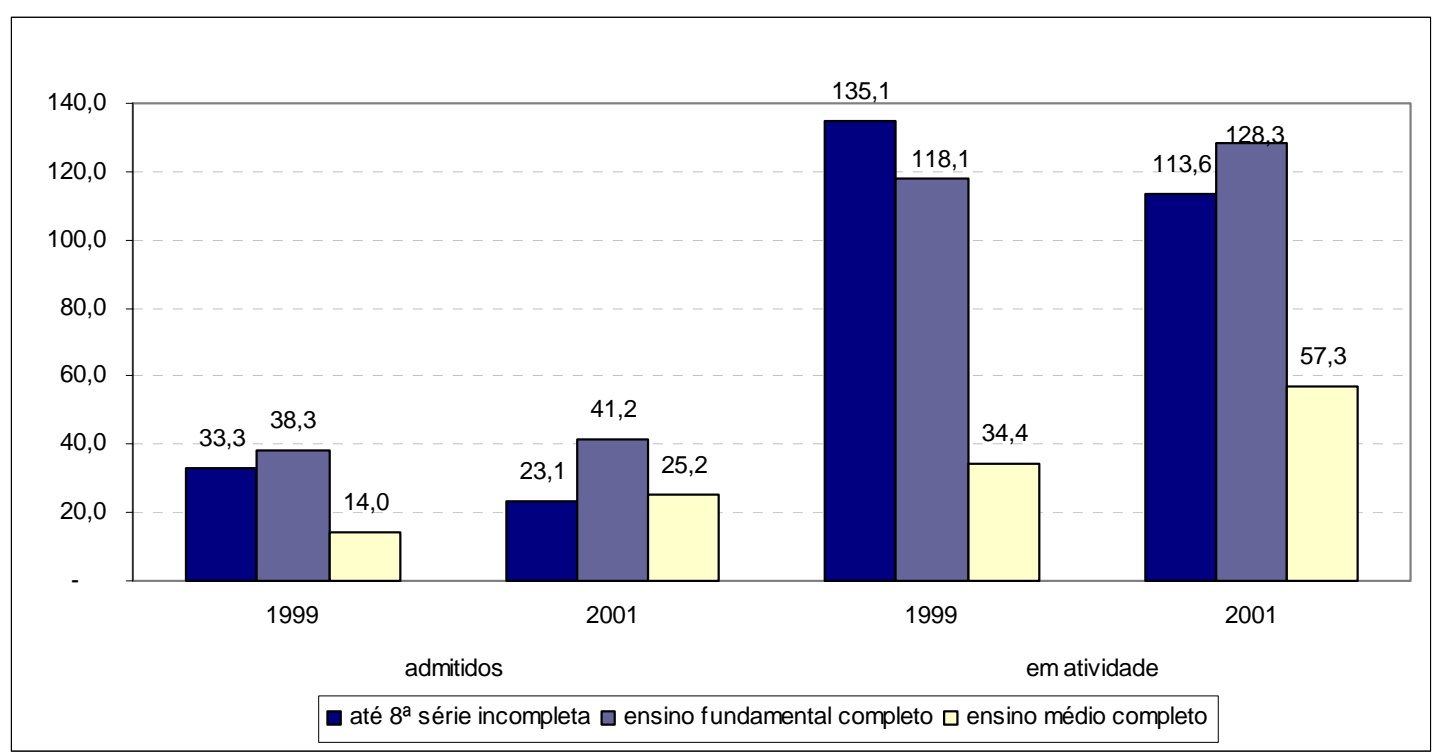

Figura 4 - Evolução do grau de instrução dos vigilantes (em milhares)

Fonte: Brasil (1999 - 2001)

Camargo (2002) e Gonzaga (2003) ressaltaram o papel das instituições no mercado de trabalho como um dos aspectos de maior influência na rotatividade dos trabalhadores. Desligamentos seriam afetados por incentivos específicos da justiça do trabalho, do código trabalhista e da legislação complementar, que, segundo esses autores, estariam repletos de ambigüidades. Criadas para servirem de barreiras às demissões, como apontou Gonzaga (2003), compensações excessivas tenderiam a incentivar o rompimento da relação de trabalho por iniciativa do empregado, segundo Camargo (2002).

Estudo do setor de segurança privada (2004) apontou que custos rescisórios são, em grande medida, os responsáveis pelo passivo trabalhista elevado das empresas, inclusive o passivo oculto que surge das prolongadas disputas judiciais nos fóruns trabalhistas, sendo a rotatividade responsável pela dificuldade em cumprir tais obrigações. Estimativas da Federação Nacional das Empresas de Vigilância e Transporte de Valores estabelecem que os encargos aumentam os gastos com pessoal em $82 \%$. 


\subsubsection{Remuneração dos trabalhadores}

Neri (2000) apresentou resultados que mostram como contratantes de trabalhadores informais também incorrem em custos de encargos sociais. segundo o autor, isso ocorre porque a justiça do trabalho pode garantir aos trabalhadores informais o recebimento de benefícios legalmente constituídos, acrescidos de multas e reajustes. Muitos contratantes incluem no acordo informal um pagamento equivalente ao recolhimento de encargos, como o FGTS e o INSS, por exemplo, buscando evitar ações na justiça. Uma importante vantagem das empresas legalmente constituídas e autorizadas deve-se, justamente, à menor possibilidade de se envolverem em problemas judiciais. A aplicação desta hipótese na segurança privada, contudo, é questionável, dada a dificuldade que um trabalhador não reconhecido pelo Departamento de Polícia Federal teria em reivindicar seus direitos, por ter, ele próprio, agido ilegalmente.

Dados do Cadastro Central de Empresas, do IBGE, que referem-se ao total para o país no ano de 2001, permitem uma comparação das remunerações médias na atividade de investigação, vigilância e segurança com as remunerações em outras atividades destacando a importância do setor (Figura 5). Dividindo os valores anuais dos salários pelo número de assalariados, verifica-se que, , cerca de 56\% dos assalariados recebeu uma remuneração anual inferior a R\$ 10 mil no período da análise. Observa-se, ainda, que o salário médio na atividade de investigação, vigilância e segurança, que é de R\$ 7,91 mil, foi superior ao pago a $40 \%$ dos assalariados. 


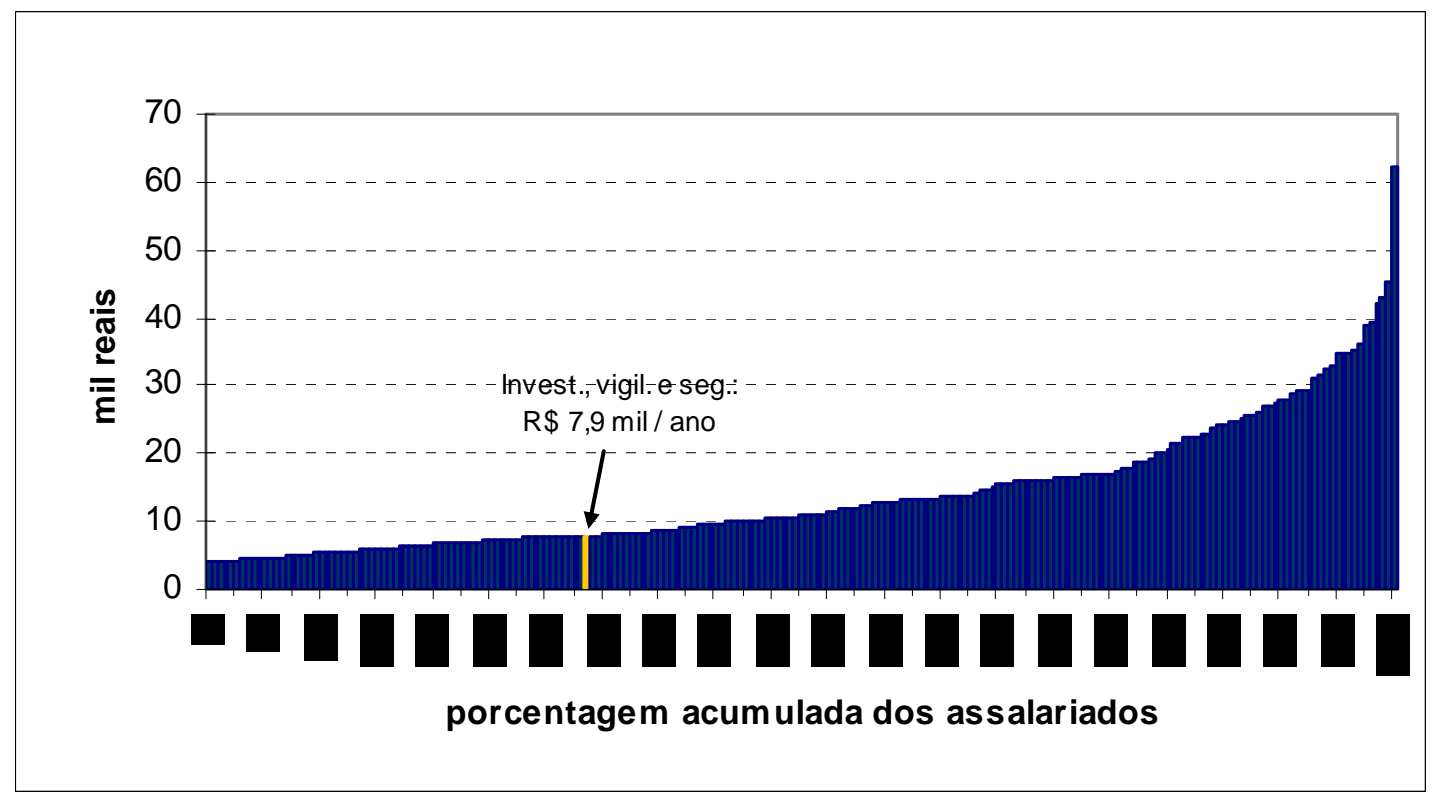

Figura 5 - Percentagem acumulada do total de vigilantes em atividade em empresas de segurança privada, por faixa salarial $(\mathrm{R} \$ 1.000,00)$ no Brasil, 2001

Fonte: IBGE (2001)

Entre os vigilantes que receberam na faixa de $\mathrm{R} \$ 7$ mil a $\mathrm{R} \$ 9$ mil por ano, estão trabalhadores com algum grau de treinamento ou qualificação, ligados à atividades agrícolas e de extração de minério; de agroindústrias; das indústrias gráfica, têxtil e metalúrgica; da construção civil; de atividades imobiliárias e aluguel de máquinas e equipamentos; do comércio atacadista e representação; dos serviços de instalação de máquinas e equipamentos e do transporte terrestre (CEMPRE/IBGE, 2001)

A importância dos gastos com mão-de-obra para empresas de segurança privada fica evidente com os dados da PAS/IBGE, de 2001, ao exibir que 74\% da receita operacional líquida dessas empresas tem esta finalidade. Um montante de 49,5\% da receita operacional líquida é apropriado pelo pessoal ocupado no setor de segurança a título de salários e outras remunerações ${ }^{1}$, sendo que $24,5 \%$ da receita operacional líquida

\footnotetext{
${ }^{1}$ Segundo a PAS, o item salários e outras remunerações refere-se a importâncias pagas a título de salários fixos, honorários da diretoria, comissões sobre vendas, horas extras, participação nos lucros, ajudas de custo, $13^{\circ}$ salário, abono financeiro de $1 / 3$ das férias, sem dedução das parcelas correspondentes às cotas do INSS ou de consignação de interesse de empregados.
} 
corresponde às obrigações perante o INSS, recolhidas ou não, tais como o FGTS, indenizações por dispensa e benefícios aos empregados.

A diferença entre a remuneração média na segurança privada e a remuneração média do pessoal ocupado no setor de serviços não-financeiros era reduzida em 2001, conforme dados da PAS mostrados na Figura 6. Verifica-se que a remuneração na segurança privada estava em torno de $\mathrm{R} \$ 8$ mil, 18,9\% superior a 1998, enquanto que nos serviços não-financeiros a remuneração média anual era de $\mathrm{R}$ \$ 8,6 mil em 2001, 0,8\% inferior a 1998 em termos nominais (Figura 6), o que significa que em termos médios os vigilantes tiveram uma melhoria da remuneração dos vigilantes em relação ao setor de serviços como um todo.

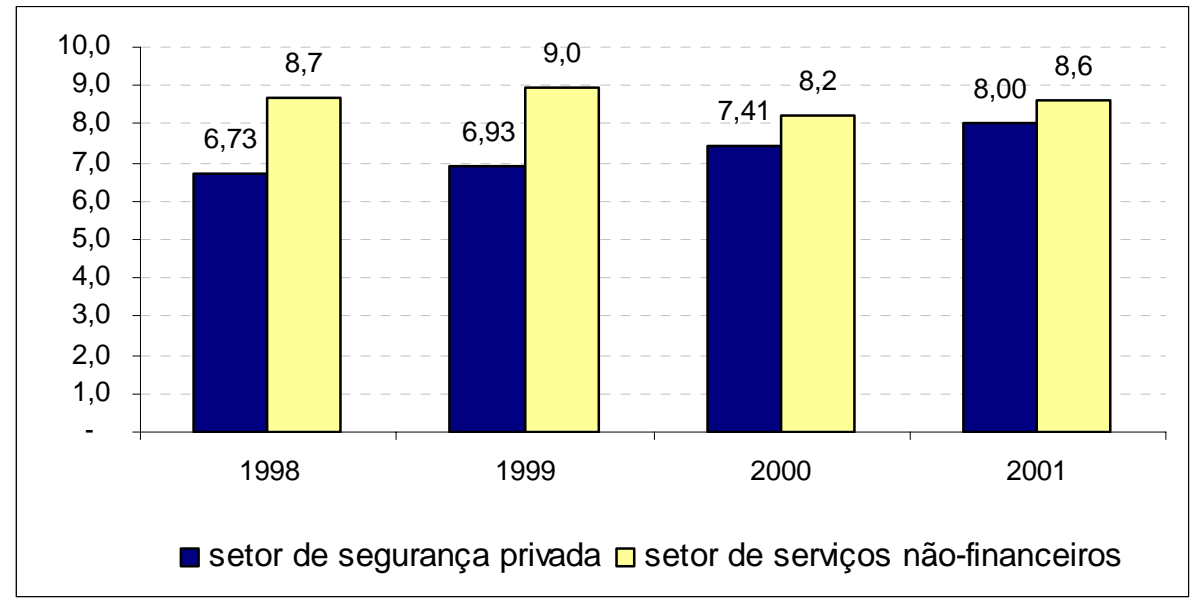

Figura 6 - Evolução da remuneração média anual de pessoal ocupado no setor de segurança privada e no setor de serviços não financeiros, de 1998 à 2001 (em R \$ milhares)

Fonte: IBGE (1998 - 2001)

A remuneração mediana da categoria indica que a remuneração no setor de segurança privada é relativamente mais alta que em outras atividades, devendo-se ressaltar, no entanto, que os requisitos para o trabalhador nessa atividade, são também relativamente maiores. Cursos de formação de vigilantes, por exemplo, podem ser 
realizados em um intervalo de tempo relativamente curto, compreendendo 120 horas de aula.

Trabalhadores informais conseguem salários bem inferiores a esses níveis praticados nas empresas de segurança. Estudo do setor de segurança privada (2004) destacou que a redução de preços dos serviços oferecidos é forçosa com a concorrência desleal, levando empresários a eliminarem gastos com horas extraordinárias como parte da contenção de custos.

Conforme Estudo do setor de segurança privada (2004), o piso salarial foi reajustado, entre 1999 e 2002, em 26,3\%, valor próximo ao INPC acumulado de 28\%, no entanto, houve no período uma tentativa de redução de horas extraordinárias nas remunerações dos vigilantes, ligadas à modificações nas escalas de trabalho. Dados da RAIS indicam que o valor médio dos salários pagos aumentou de R\$ 561,00 para R\$ 648,00 entre 1999 e 2001 (incremento de 15,5\%), ante um reajuste do Índice Nacional de Preços ao Consumidor (INPC) acumulado de 43,3\%. Em 2001, o piso salarial da categoria atingia em 14 estados até dois salários mínimos, enquanto nos onze restantes ficava entre dois e três salários mínimos. Os pisos variaram entre estados, assim como partes variáveis da remuneração referentes a compensação por risco de vida, e, por exemplo, a prêmios pela assiduidade, conforme Estudo do setor de segurança privada (2004). Há uma concentração de vigilantes na faixa de remuneração entre 2,01 e 4 salários mínimos, como pode ser visto na Figura 7. 


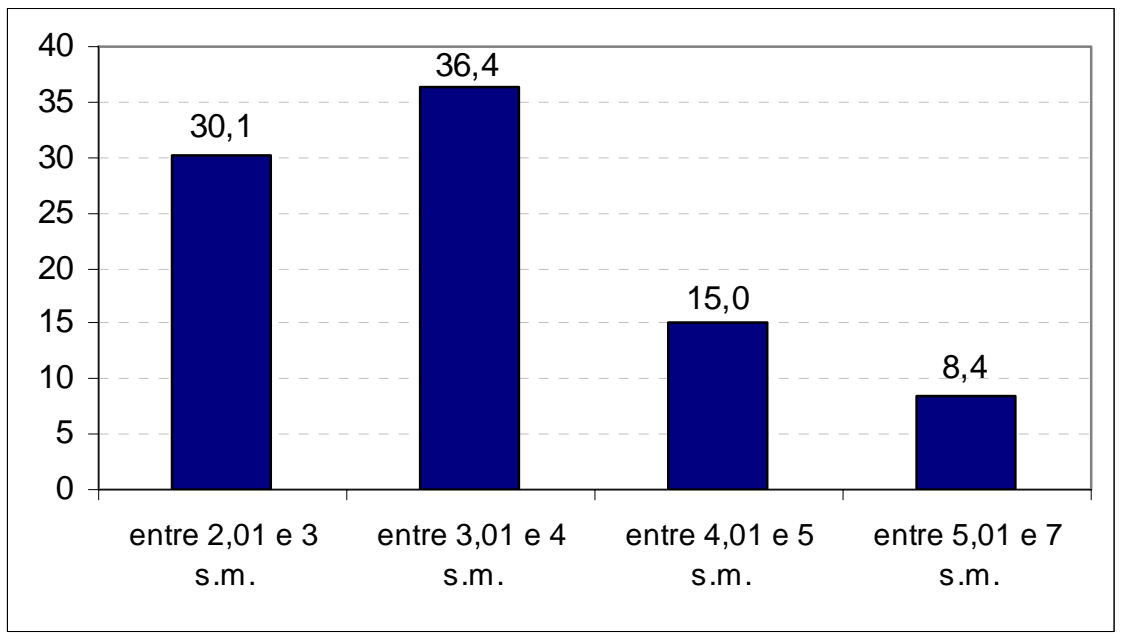

Figura 7 - Participação das principais faixas salariais no rendimento de vigilantes no Brasil, em 2001 (em \%)

Fonte: Brasil (1995 - 2001)

Verifica-se que entre 1999 e 2001 houve um aumento significativo da contratação de vigilantes com remunerações de até três salários mínimos. As contratações para a faixa de 4,01 a 5 s.m. diminuíram de $14,4 \%$ para $8,5 \%$ do total de admitidos e, entre 5,01 e 7 s.m., de 7,8\% para 4,4\%. Entre 1999 e 2001, 70,8\% da "nova força de trabalho" era empregada com ganhos entre 2,01 e 4 s.m., ante 57,4\% de vigilantes demitidos com o mesmo ganho (ver Tabela 4). 
Tabela 4. Distribuição de vigilantes admitidos e desligados por faixa salarial para os anos de 1999 e 2001; Brasil (em \%)

\begin{tabular}{|c|c|c|c|c|}
\hline \multirow{2}{*}{$\begin{array}{c}\text { Faixa salarial } \\
\text { (em salários mínimos) }\end{array}$} & \multicolumn{2}{|c|}{ admitidos } & \multicolumn{2}{|c|}{ desligados } \\
\hline & 1999 & 2001 & 1999 & 2001 \\
\hline Até 0,5 & 0,08 & 0,09 & 0,12 & 0,11 \\
\hline 0,51 a 1,0 & 0,21 & 0,42 & 0,37 & 0,42 \\
\hline 1,01 a 1,5 & 0,72 & 1,37 & 0,90 & 1,04 \\
\hline 1,51 a 2,0 & 3,49 & 9,31 & 2,99 & 5,72 \\
\hline 2,01 a 3,0 & 26,89 & 41,24 & 21,43 & 28,79 \\
\hline 3,01 a 4,0 & 41,63 & 31,94 & 31,07 & 32,28 \\
\hline 4,01 a 5,0 & 14,37 & 8,50 & 16,98 & 13,20 \\
\hline 5,01 a 7,0 & 7,77 & 4,36 & 13,28 & 9,04 \\
\hline 7,01 a 10,0 & 2,63 & 1,15 & 5,17 & 4,09 \\
\hline 10,01 a 15,0 & 1,06 & 0,78 & 2,73 & 2,32 \\
\hline 15,01 a 20,0 & 0,35 & 0,20 & 1,38 & 0,89 \\
\hline Mais de 20,0 & 0,38 & 0,41 & 2,21 & 1,60 \\
\hline Ignorado & 0,41 & 0,23 & 1,35 & 0,52 \\
\hline
\end{tabular}

Fonte: Brasil (1999, 2001)

Há duas hipóteses para explicar esse movimento: substituição deliberada por mão-de-obra mais barata e características dos mercados regionais. A primeira considera que a mão-de-obra mais barata, que recebia entre 4,01 e 7 salários mínimos, representavam $26,4 \%$ dos demitidos, enquanto apenas $18,1 \%$ dos admitidos pertenciam a essa faixa de remuneração.

A segunda hipótese considera que a taxa de turnover regional é diferente em função das diferenças na composição da demanda e da escolaridade entre as regiões, o que parece ser um argumento mais sólido que o primeiro. No Norte, Nordeste e CentroOeste, regiões menos industrializadas e com nível de escolaridade mais baixo, o turnover é reduzido. Como o setor público é o principal cliente, verificam-se contratos 
prolongados de prestação de serviços, sendo as demissões pelo término desses contratos menos freqüentes. A incerteza quanto à qualidade da mão-de-obra é possivelmente maior nas regiões Sudeste e Sul, que possuem escolaridade média mais elevada, mas por ser na maioria referente a trabalhadores com educação secundária, problemas de assimetria de informações podem persistir.

\subsubsection{Outras remunerações e despesas}

Os dados sobre os lucros não são disponíveis para consulta, mas considera-se que o movimento nesta variável tende a acompanhar as oscilações no excedente operacional bruto, divulgado na Pesquisa Anual de Serviços (PAS; 2001),. Segundo essa mesma fonte, em 2001, o excedente operacional bruto representava cerca de 10,7\% da receita operacional líquida dos serviços de investigação e vigilância.

O uso de outros insumos para a prestação de serviços de segurança privada absorveu 17,6\% da receita operacional líquida, segundo a Pesquisa Anual de Serviços (PAS) de 2001. A inter-relação da atividade com outros serviços aparece no principal componente do consumo intermediário, que, no caso, são os serviços prestados por pessoas jurídicas, como ressalta Estudo do setor de segurança privada (2004). Somandose a esses o valor dos serviços de profissionais liberais e autônomos, tem-se que 21,6\% do consumo intermediário destinado para serviços, segundo os dados da PAS de 2001.

Outros serviços típicos prestados para segurança privada são os seguros e as comunicações. O valor pago pelas empresas na contratação de seguros, em 2001, foi de R\$ 65 milhões, 6,6\% do consumo intermediário (PAS, 2001). Esse número é relativamente alto, o que se deve, possivelmente, aos maiores riscos envolvidos na atividade. Serviços de comunicação são componentes em que a presença de tecnologia moderna é tipicamente maior, mas representam apenas 5,9\% do consumo intermediário total (PAS, 2001).

Dentre os gastos com materiais, dois grupos de despesas, típicos do transporte de valores e da escolta armada, apresentam valores elevados no consumo intermediário de insumos das atividades de investigação e segurança privada. Esses são os aluguéis e o arrendamento de veículos, máquinas e equipamentos, com $14,3 \%$ do consumo 
intermediário, somados com gastos em combustíveis e lubrificantes, com 11,5\% (PAS, 2001). Bens incluídos no item mercadorias, materiais de consumo e de reposição são de usos diversos e perfazem cerca de $14,1 \%$ dos gastos no consumo intermediário de bens e serviços (PAS, 2001).

Cabe destacar, ainda, que em 2001, registrou-se um montante de despesas financeiras e variações monetárias passivas da ordem de $\mathrm{R}$ \$ 159,5 milhões de reais nos serviços de segurança privada.

\subsubsection{Tributos}

Para a segurança privada, segundo a PAS/IBGE, existem deduções da ordem de $6,8 \%$ sobre a receita operacional bruta em 2001. São valores deduzidos diretamente do faturamento bruto da empresa que, segundo essa fonte, devem incluir vendas canceladas, abatimentos e descontos, o imposto SIMPLES, o ICMS e outros impostos e contribuições sobre vendas e serviços (IPI, ISS, PIS, COFINS, etc.). Como o estabelecido pela legislação, no ano de 2001, o PIS correspondeu a $0,65 \%$ e a COFINS a $3 \%$ do faturamento das empresas. Subtraindo essas alíquotas do percentual das deduções sobre a receita operacional bruta, restam 3,13\% destinados ao ISS, às vendas canceladas e abatimentos e descontos. Isto fornece uma referência para carga tributária no setor devida ao ISS, um valor próximo a $3 \%$ se forem pequenas as vendas canceladas, os abatimentos e os descontos.

A Emenda Constitucional 37 de 12/06/02 fixou que a alíquota mínima do ISS deveria ser de $2 \%$, uma medida para o combate à guerra fiscal entre municípios. A fixação da alíquota mínima foi seguida do estabelecimento do teto do ISS em 5\% e, também para combater a guerra fiscal, de uma importante modificação do local da cobrança do tributo para o município onde a prestação do serviço é realizada (Lei Complementar 116 de 31/07/03). Os estímulos em estabelecer empresas em municípios cujas alíquotas do ISS são menores, são eliminados com esta alteração legal.

$\mathrm{Na}$ Figura 8 é apresentada a evolução dos gastos com tributos, a partir dos dados da PAS/IBGE. 


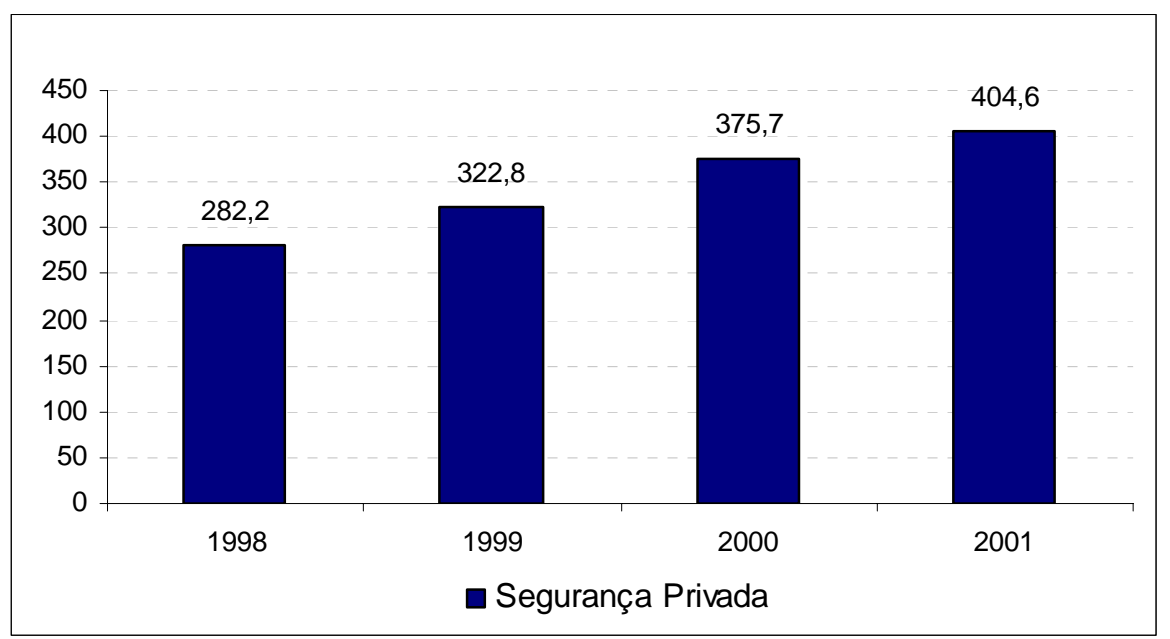

Figura 8 - Tributos pagos pelas empresas no setor de segurança privada e pelo setor de serviços não-financeiros no Brasil (em R \$ milhões)

Fonte: IBGE (1998 - 2001)

\subsubsection{Distribuição geográfica dos serviços}

Estudo do setor de segurança privada (2004) mostra que a distribuição geográfica dos serviços de segurança acompanha a distribuição espacial de outras atividades econômicas no Brasil. Isso foi interpretado como reflexo a destinação de defesa do patrimônio, de proteção a pessoas de alto poder aquisitivo, como moradores de prédios e condomínios fechados, e empresas privadas industriais, comerciais e financeiras, que realizam elevado número de transações e terceirizam as atividades de segurança. destacou-se que existe, por exemplo, uma ampliação de empresas com espaços abertos ao público em geral, como shoppings centers, em grande quantidade na região Sudeste.

A receita bruta dos serviços de investigação, vigilância, segurança e transporte de valores é bem maior nessa região, agregando $62,2 \%$ do total, e totalizando um valor bem próximo da concentração da receita bruta dos serviços não financeiros, registrada em $67,2 \%$ da receita bruta nacional. Esta distribuição espacial da receita bruta é comum para outras variáveis, como o número de empresas, com 57,3\% na região sudeste, o pessoal ocupado, com 55,6\% no sudeste, e os salários, retiradas e outras remunerações, com 55,6\% (Figura 9). 


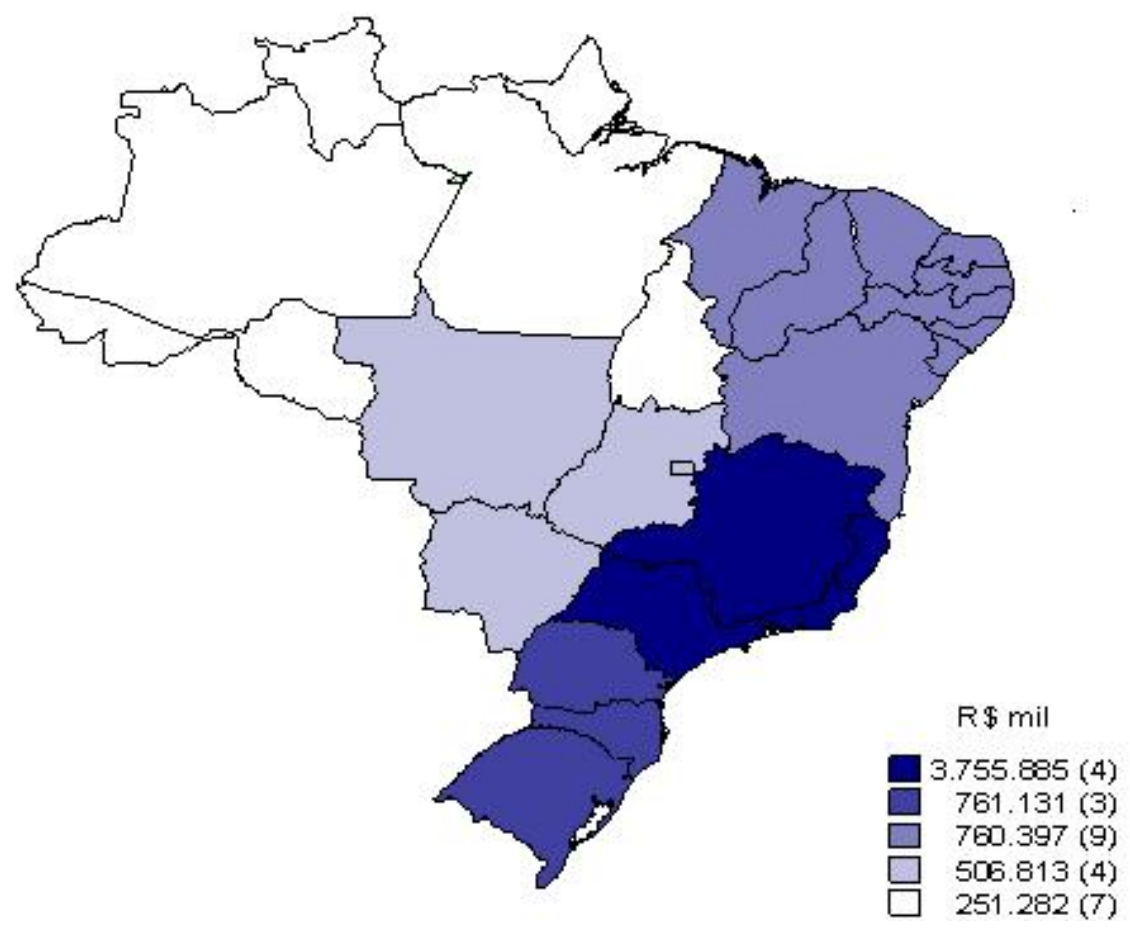

Figura 9 - Distribuição Regional da Receita Bruta dos Serviços de Investigação, Vigilância, Segurança e Transporte de Valores no Brasil, 2001 (em mil R\$) Fonte: IBGE (2001)

Dados de criminalidade da Secretaria Nacional de Segurança Pública mostram outras informações que podem justificar esta distribuição. Os dados mostram 307 ocorrências de extorsão mediante seqüestro em São Paulo no ano 2001, um número oito vezes maior que o segundo colocado, Minas Gerais, com 38 ocorrências. Os registros de furtos e de roubos mostram, respectivamente, 553 mil e 320 mil ocorrências no estado de São Paulo em 2001, mais que o dobro das ocorrências registradas no segundo colocado, o Rio Grande do Sul. 


\subsubsection{A segurança privada nos grandes centros urbanos}

Em linhas gerais, a expansão da segurança privada acompanha a evolução das mudanças na organização do espaço urbano, emergindo da busca de mecanismos eficientes de defesa dos direitos de propriedade por pessoas e pela coletividade. Pesquisas na área da sociologia costumam estudar a evolução da segurança privada relacionada com as mudanças na criminalidade e na provisão de segurança pública, principalmente nos grandes centros. Caldeira (2000) destacou que o medo e as notícias de violência difundidos na coletividade estimulam a reação de indivíduos e grupos sociais no sentido de aumentar a defesa de sua propriedade com a restrição da interação e dos movimentos das pessoas, principalmente com o aumento das falhas das instituições em ordenar a convivência social. A autora expõe fatores sociais, institucionais e econômicos condutores dos processos, comuns e cada vez mais presentes, de fortificação das residências e de formação de condomínios e áreas de convivência social restrita.

É interessante ressaltar que o movimento de formação de condomínios e áreas residenciais acontece também fora do Brasil. Nelson (2000), mostrou o crescimento de moradias em áreas de cooperativas, associações e condomínios nos Estados Unidos. Segundo o autor, em 1970, cerca de 1\% das moradias americanas eram localizadas em tais áreas, enquanto que em 1998, o número havia passado para cerca de $15 \%$. A expansão da propriedade coletiva, que essas formas de organização representam, mostram uma verdadeira revolução na governança local dos recursos. O autor destaca, ainda, que cerca de 50\% das novas unidades residenciais são construídas e vendidas como parte desses espaços coletivos, que delegam a organizações privadas cada vez mais a responsabilidade pela provisão de serviços coletivos como coleta de lixo, manutenção de áreas de recreação e segurança. $\mathrm{O}$ argumento desenvolvido no texto indica que este tipo de ocupação cria um mecanismo privado para regular a qualidade do ambiente exterior, que estabelece regras diferentes para sua constituição que as tradicionalmente estabelecidas pelo setor público, com uma grande flexibilidade de criação de normas para a coletividade. A sugestão do autor é que haja uma privatização de cada área, ao invés do controle comumente realizado nos locais. 
De acordo com Nelson (2000), nos últimos quarenta anos do século XX a propriedade privada na forma de residências passou por um processo de desenvolvimento de mecanismos de controle sobre as características da vizinhança que lhes interessavam, principalmente aquelas que poderiam gerar economias de escala na produção.

\subsubsection{Regulamentação da atividade}

De acordo com Cubas (2002), no Brasil os serviços de vigilância foram criados na década de 1960, a partir de firmas que prestavam serviços terceirizados de limpeza e portaria nos bancos. Para a autora, o aumento acentuado do número de empresas aconteceu nos anos 90 com as dificuldades de serviços públicos garantirem a oferta de segurança e o barateamento dos equipamentos eletrônicos.

A disciplina legal da segurança privada começou em 1966, com os Decretos-Leis no.1.212 e no.1.216, que viabilizaram a contratação de empresas de segurança por bancos, conforme relatado por Conceição (2002). Segundo Cubas (2002), em 1969, foi decretada a lei NO. 1.034, que estabeleceu claramente que os bancos deveriam contratar empresas especializadas na prestação dos serviços de segurança. Esta lei regulamentava a prestação de serviços terceirizados de segurança e colocava a necessidade de aprovação dos ocupantes de postos de trabalho pelo Departamento de Polícia Federal. Musumeci (1998) destacou que a legislação surgiu para combater assaltos praticados por grupos "subversivos", mas destaca que a expansão da atividade na década de 1970 levou a problemas de não cumprimento da legislação pelas empresas, envolvimento de vigilantes em ações criminosas, emprego de uma mão-de-obra com baixo nível sócio-educacional e crescimento da atividade ilegal no setor, de empresas clandestinas, policiais na ativa e pessoas sem qualquer formação. Isto reflete a tendência de deterioração da qualidade dos serviços sem a imposição de regulamentos e a criação de barreiras à atuação no mercado, que acontece quando o mercado é desregulamentado.

Em 1983, O Decreto-Lei 1.034/69 foi revogado pela lei 7.102, que estabeleceu as normas para a constituição das empresas. Conforme Musumeci (1998) e Cubas (2002), a transferência de responsabilidade pelo controle e fiscalização da segurança privada da 
esfera estadual para a federal, retirando poder das Secretarias de Segurança Pública, ocorreu pelo interesse de um lobby que expressava as queixas dos empresários com relação aos entraves burocráticos específicos em cada Estado. A lei 7.102/83 deixou o controle e a fiscalização da segurança privada no Brasil ao encargo do Ministério da Justiça, até o ano de 1995, quando a lei 9.017 transferiu para o Departamento de Polícia Federal (DPF) a completa responsabilidade de regular o setor.

A transferência da competência para controlar e fiscalizar a segurança privada levou a direção geral do DPF a disciplinar seus procedimentos internos e a criar um setor específico de controle da segurança privada e uma série de superintendências regionais, as Delegacias de Controle de Segurança Privada (DELESP) ${ }^{2}$. Atualmente, o DPF é o órgão responsável pelo controle normativo, coordenação e fiscalização a regulação do setor, exercendo suas atividades sob a disciplina das leis $\mathrm{n}^{\circ} 7.102$ de 1983, 8.863 de 1994 e 9.017 de 1995; decretos 89.056 de 1983 e 1.592 de 1995; portarias 601 de 1986, 214 de 1989, 091 de 1992 e 1.129 de 1995, do Ministério da Justiça; portarias 992, 277, 891 e 836, do Departamento de Polícia Federal. O órgão regula as empresas que exercem atividades de vigilância, transporte de valores, escolta armada, segurança pessoal, cursos de formação de vigilantes e serviços orgânicos. As armas são registradas em nome das empresas, que têm que obedecer A critérios específicos para sua aquisição, tanto no que diz respeito à quantidade quanto ao tipo de armamento.

Destaca-se que os regulamentos que controlam os serviços de segurança privada não são uma mera aplicação da lei que governa os serviços públicos aos espaços privados. Os serviços de vigilantes não possuem a legitimidade para estabelecer inquéritos policiais, cuidar da preservação da ordem pública, fiscalizar e controlar as atividades ligadas à segurança privada e cuidar de presídios, como destacou Musumeci (1998). A autonomia para estabelecer procedimentos em propriedades livra, no entanto, as empresas de formalismos que protegem indivíduos no espaço público.

\footnotetext{
${ }^{2}$ DEPARTAMENTO DE POLÍCIA FEDERAL. Serviços à comunidade: empresas de segurança privada. http://www.dpf.gov.br/ (04 nov. 2004)
} 


\section{REVISÃO DE LITERATURA}

A análise da segurança privada conduzida no presente estudo, compreende as características e finalidades pretendidas para os serviços, das transações, das instituições e das estruturas de governança entre agentes no setor. Conceitos da Nova Economia Institucional (NEI), apresentados neste capítulo, constituíram-se na base teórica selecionada para a compreensão de como ocorre a coordenação de agentes na cadeia de prestação de serviços, buscando entender como estruturas de governança distintas estabelecem mecanismos de controle, de incentivos e de adaptação para a condução de transações, dado um ambiente institucional e as características das transações realizadas.

O marco teórico empregado fundamenta a identificação dos agentes e das relações no sistema de prestação de serviços de segurança privada, que são apresentados de forma mais detalhada na análise de resultados no capítulo 5.

Discute-se aspectos de falhas do mercado na presença de externalidades e de bens públicos, que são tradicionalmente apontadas como justificativas para a provisão de serviços de policiamento pelo Estado, cujas falhas, no entanto, deixam espaço para a contratação de serviços privados. Este capítulo enfoca os problemas causados por uma terceira causa de falha do mercado, a assimetria de informações, que interfere diretamente na capacidade de criar incentivos e estabelecer mecanismos de controle nas transações. O impacto da assimetria de informação estende-se às estruturas de governança hierárquica e híbridas, que no entanto, têm as possibilidades de melhorar incentivos através da prática de salário de eficiência e de utilizar estratégias de sinalização e filtragem na superação de problemas criados pela assimetria de informações. 


\subsection{Nova Economia Institucional - aspectos gerais}

Conforme North (1990), a Nova Economia Institucional (NEI) auxilia A compreensão das instituições na economia, modificando a teoria neoclássica, para nos limites de sua visão sobre a condução eficiente de transações por mercados e firmas. Milgrom e Roberts (1992) afirmam que a análise da eficiência de organizações é sistêmica e bem mais complexa que a análise de eficiência produtiva da economia neoclássica, exigindo que maior significado seja dado às noções de negociação, implementação e instrumentos que forçam o cumprimento de acordos.

A NEI divide-se em duas correntes principais de pesquisa, tratando da interferência de níveis analíticos distintos na promoção da eficiência de um sistema produtivo, em termos de cooperação e de competição entre participantes. O primeiro nível analítico focalizado está voltado para a análise do ambiente institucional, de macroinstituições que estabelecem regras gerais, enquanto o segundo refere-se ao entendimento de microinstituições, as estruturas de governança que determinam como as transações são efetivamente conduzidas. Visando integrar as correntes da NEI, distintas pelo foco nesses dois níveis analíticos, Williamson (1996) apresentou uma esquematização da NEI incluindo o nível dos indivíduos, reproduzida na da Figura 10. Esta representação mostra as interações principais, representadas por setas sólidas, e as secundárias, empregando setas pontilhadas, entre os níveis analíticos essenciais para a análise de custos de transação pela NEI. 


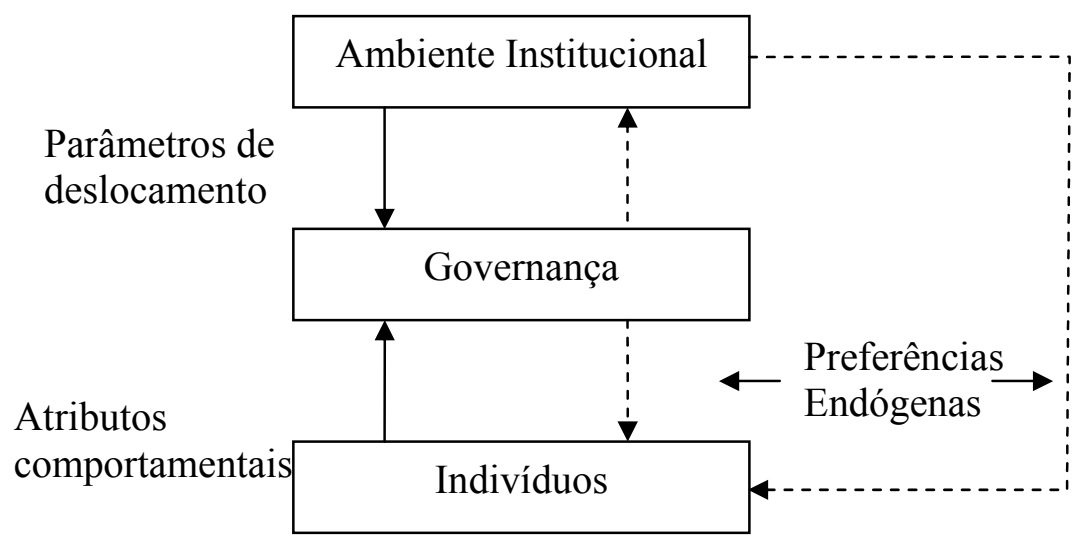

Figura 10 - Esquema de três níveis

Fonte: Williamson (1996)

No nível mais elevado da Figura 10 tem-se o ambiente institucional, que representa um conjunto de regras políticas, sociais e legais, formalizadas ou não, que condicionam as atividades de produção, troca e distribuição de produtos. Este ambiente contém regras que condicionam diretamente as estruturas de governança e, de maneira secundária, preferências dos indivíduos formadas endogenamente. Mudanças no ambiente institucional modificam parâmetros de custos comparativos de diferentes estruturas de governança, tornando uma forma ou outra de conduzir transações momentaneamente mais competitivas. Embora o foco da NEI, para Williamson (1996), esteja nas condições que o ambiente institucional impõe sobre as estruturas de governança, a Figura 10 apresenta também um efeito inverso de determinação de macroinstituições por estruturas de governança. North (1995) destacou essa função da NEI em compreender como, ao longo do tempo, se estabelecem as instituições econômicas e políticas capazes de reduzir os custos de transação, muito embora o estudo de sistemas produtivos considere este tratamento secundário. 
No nível central da Figura 10 estão as estruturas de governança das transações, que vão dos extremos de transações impessoais, conduzidas pelos mercados, à forma hierárquica de transações integradas em processos produtivos das empresas. Existem, ainda, uma série de formas híbridas intermediárias de coordenação das transações firmadas por relações contratuais de longo prazo. Conforme Zylberstajn (1995), as estruturas de governança são fortemente condicionadas pelos atributos das transações, pelo ambiente institucional e pelo comportamento dos indivíduos, mas secundariamente moldam o ambiente institucional e as preferências endógenas de indivíduos.

$\mathrm{Na}$ base da Figura 10 tem-se os indivíduos, para os quais apresentam-se duas pressuposições comportamentais: o oportunismo e a racionalidade limitada. O postulado de racionalidade limitada, proposto por Simon (1957), estabelece que os indivíduos conseguem vislumbrar parte dos aspectos de uma transação, existindo um custo para utilizar o recurso de "racionalidade" e não utilizando todo o conjunto de informações disponível para a tomada de decisão, como a economia neoclássica o faz com a idéia de racionalidade ilimitada, como explica Machado (2002). A racionalidade limitada dos agentes, com distribuição assimétrica de informações, leva, inevitavelmente, ao surgimento de custos de transação e inviabiliza o estabelecimento de um contrato completo, que incorpore em suas cláusulas termos para a resolução de todos os conflitos ligados a contingências futuras.

Milgrom e Roberts (1992) destacam dentre as causas da existência de contratos incompletos a impossibilidade de antever todas as circunstâncias futuras, os custos de mensurar e estabelecer termos contratuais detalhados, e a imprecisão da linguagem empregada nos contratos.

O segundo pressuposto adotado pela NEI sobre o comportamento dos indivíduos, é de um auto-interesse ávido no comportamento dos indivíduos, ou oportunismo forte. Nessa concepção, os indivíduos ocultam informações fundamentais por ocasião da elaboração de contratos e estabelecem termos desvantajosos, no que se conhece por oportunismo pré-contratual, além de não assegurarem o cumprimento dos termos acordados quando da efetivação das transações, no que se convenciona chamar de oportunismo pós-contratual. Quando os agentes não se comportam de maneira 
oportunista, os problemas de custos de transação tornam-se pouco expressivos, pois a maioria dos eventos não antecipados e refletidos em termos contratuais não provoca alterações expressivas nos objetivos que devem ser atingidos, bem como na distribuição de custos e benefícios entre as partes, como destacam Milgrom e Roberts (1992).

Formas contratuais apresentadas por Williamson (1996) aparecem ligadas com estruturas de governança genéricas. Para o autor, contratos são desenhados com base em três formas de leis contratuais: a clássica, a neoclássica, e a relacional.

$\mathrm{Na}$ forma clássica, os contratos são construídos desprezando a identidade das partes, pois nenhuma relação de dependência é estabelecida entre essas, correspondendo a transações realizadas via mercado. As transações são monetizadas e a resolução de disputas é viabilizada por termos formais dos contratos. Em mercados do tipo spot, como explicam Milgrom e Roberts (1992), é difícil a alteração de circunstâncias antes de um contrato expirar, tornando menores os custos de escrever termos contratuais. Conforme Lyons (1994), se os insumos de produção forem padronizados e mudanças imprevistas controladas, os contratos poderão ser efetivos.

$\mathrm{Na}$ forma neoclássica, os contratos são desenhados numa circunstância de dependência bilateral entre partes que mantêm um grau de autonomia, permitindo adaptações eficientes às circunstâncias não previstas. Os contratos do tipo neoclássico, segundo Williamson (1996), contemplam adaptações a distúrbios não antecipados, criam uma zona de tolerância dentro das quais "desalinhamentos" de interesses são absorvidos, requerem abertura de informações para consubstanciar adaptações propostas, provendo espaço para a arbitragem de disputas por uma terceira parte. As formas híbridas são sustentadas por este tipo de contrato, desde que distúrbios não tenham conseqüências graves e a necessidade de adaptação seja limitada.

A terceira forma de contrato refere-se à relacional, ligada com uma estrutura hierárquica de governança das transações. A capacidade adaptativa é ressaltada nesta forma de relação contratual, em que Williamson (1996), explica ser originada dos contratos de trabalho. Nesta forma contratual existe uma contínua negociação entre as partes, sem a interferência de uma terceira parte para arbitragem de disputas. Termos iniciais de um acordo podem ser revistos ao longo do tempo, para garantir a 
continuidade de uma relação. A estrutura de incentivos - determinada por remunerações inflexíveis-, é relativamente baixa na hierarquia, isto é, existe uma baixa associação entre esforços e recompensas. Os incentivos mantidos constantes, como sustenta o autor, favorecem a cooperação entre indivíduos, mas se ganhos não são percebidos a longo prazo, tende a ocorrer um enfraquecimento dos acordos. A resolução de disputas é com acordos entre partes envolvidas ou com apelo à mediação da hierarquia, porque apelo $\mathrm{A}$ cortes seriam inviabilizados pela dificuldade de comunicar circunstâncias específicas envolvidas e pelo interesse da própria hierarquia em manter a integridade da estrutura de comando.

Segundo Williamson (1996), os pressupostos comportamentais seriam importantes para distinguir modos possíveis ou não de realizar determinada contratação. Machado (2002), citando Williamson (1996), resume que um contrato incompleto seria aquele em que:

1) Nem toda contingência futura pode ser imaginada;

2) Contingências futuras que estão permeadas de detalhes obscuros;

3) Entendimento comum sobre contingências futuras não pode ser alcançado;

4) Um entendimento comum e completo das adaptações apropriadas das contingências futuras não pode ser alcançado;

5) As partes não concordam sobre qual evento contingente foi materializado;

6) Partes não concordam sobre adaptações para entender contingências que correspondam às do contrato;

7) Uma terceira parte pode não ter conhecimento sobre contingências e adaptações feitas e forçar discussões custosas entre as partes.

\subsection{A Economia dos Custos de Transação}

A escolha de uma forma contratual reflete o esforço dos indivíduos na realização de transações, ou seja, reflete os custos de transação, que na concepção de Arrow (1969), são os custos de movimentar sistema econômico. Os custos de transação dizem respeito aos custos de obtenção de informações sobre preços e qualidades dos produtos, custos de realizar barganhas, de elaborar contratos e monitorar desempenho, além de 
custos de proteger direitos de propriedade. Para North (1995) são os custos envolvidos na coordenação de partes interdependentes do sistema econômico e os custos de forçar o cumprimento de acordos.

A análise dos custos de transação oferece a oportunidade de explicar o surgimento das firmas, sendo o trabalho de Coase (1937) seminal para o entendimento dos aspectos microinstitucionais que estabelecem as fronteiras das firmas. Ao considerar como unidade básica de análise as transações entre indivíduos, as firmas seriam um nexo de contratos que governariam as trocas em lugar da estrutura descentralizada do mercado, se nesses os custos de transação fossem bastante elevados. Estendendo a análise de Coase (1937), Williamson (1985) estabeleceu os atributos básicos das transações que condicionariam a existência de diferentes estruturas de governança.

Williamson (1985) analisa os custos de transação em dois grupos: os custos gerados ex-ante, relacionados com a elaboração e negociação dos contratos e a procura e o conhecimento da outra parte contratante, e os custos ex-post, originados após a concretização do negócio, tais como o monitoramento das imposições contratuais, da resolução de conflitos que possam ocorrer e das readaptações que poderão ser necessárias.

Esta definição condiz com a idéia de Vining e Globerman (1999) de que o objetivo estratégico da subcontratação deve ser a minimização do custo da obtenção de uma dada quantidade ou qualidade de um bem ou atividade. Os custos seriam tanto de produção, quanto de transação, conforme relacionados a seguir:

a) custos de produção - custos de oportunidade dos recursos terra, capital e trabalho usados na produção de um serviço;

b) custos de negociação - custos de estabelecer termos contratuais; custos de mudar termos contratuais após a ocorrência de circunstâncias não previstas; custos de monitorar a performance do sub-contratado; custos de resolver disputas pela quebra de contrato;

c) custos de oportunismo - surgem quando uma das partes de um acordo age de má fé. 


\subsubsection{Atributos das transações}

Conforme Williamson (1996) descreve, as transações são cercadas de três atributos básicos: especificidade de ativos, freqüência e incerteza.

O primeiro atributo de uma transação refere-se à especificidade de ativos, que representa a dificuldade de alocar um ativo em uso alternativo sem redução substancial de seu valor produtivo, situação especialmente grave no caso de ruptura de uma relação contratual. Quanto maior a especificidade de um ativo, maior a dependência dos retornos de um investimento na continuidade da transação, o que implica a necessidade de firmar acordos de mais longo prazo e maior capacidade de adaptação por parte das estruturas de governança das transações. Dentre os tipos de especificidades, Williamson (1996) identificou seis:

a) Especificidade locacional, na qual ativos localizados proximamente criariam economias de transporte e armazenamento;

b) Especificidade física, representada pela adequação de partes a um tipo de produto;

c) Especificidade do ativo humano, que surge com o que se aprende fazendo em determinada atividade, tornando-se específico a ela;

d) Especificidade de ativos dedicados, em que há dependência do investimento com o retorno em função de um cliente em particular;

e) Especificidade temporal, que garante que a transação ocorra no espaço de tempo determinado;

f) Especificidade de marca que ocorre quando há risco e capital envolvidos no uso das marcas.

A especificidade dos ativos nas transações cria uma quase-renda, que de acordo com Klein et al. (1978), é dada pela diferença entre os rendimentos do emprego do ativo em uma transação específica em relação a rendimentos que obtidos em uso alternativo. Devido à criação da quase-renda, o investimento em ativos específicos implica na disputa entre as partes por sua repartição, criando uma dependência bilateral. Agentes oportunistas podem lutar pela apropriação unilateral de ganhos incrementais, criando conflitos e custos de transação na barganha pela divisão da quase-renda. Zylbersztajn 
(1995) acrescentou que existirão formas organizacionais melhor estruturadas na medida que os ativos são mais específicos, ou seja, associados a formas de dependência bilateral. A relação de dependência entre as partes para o uso dos ativos específicos torna a transação necessariamente mais complexa e uma coordenação maior é exigida.

O segundo atributo de uma transação refere-se à incerteza. A impossibilidade de predição dos acontecimentos, conforme Masten (1991), torna mais complexa uma transação e dificulta a descrição completa e acurada as responsabilidades de cada uma das partes contratantes. A solução de disputas fica dificultada quando do descumprimento de obrigações contratuais, sendo para as informações incompletas e imperfeitas as causas principais da incerteza, para Milgrom e Roberts (1992). Esses autores tratam a incerteza associada com a complexidade das transações na elevação dos custos de organização interna, pois transações mais complexas criam maior dificuldade de gerenciamento. A existência de incerteza tem impacto maior sobre formas híbridas de governança das transações, que dependem da elaboração de contratos para a salvaguarda de direitos no caso de contigências.

O terceiro atributo das transações é a freqüência em que essas ocorrem, sendo esta de suma importância para estabelecer uma estrutura de controle sobre as transações. Como Farina et al. (1997) estabelecem, a repetição das transações permite a diluição dos custos de adoção de um mecanismo complexo por várias transações e possibilita a construção da reputação entre os agentes. Com a freqüência elevada, o comportamento oportunista pode ser inibido com a diluição dos gastos na elaboração de um contrato formal, na coleta de informações, na adaptação às contingências e no monitoramento, além de permitir a construção de uma reputação sobre as partes que reduz o custo com a elaboração de contratos complexos.

\subsection{O ambiente institucional}

Os custos de transação estão diretamente relacionados com o ambiente institucional, explicado de forma pioneira por Coase (1957), enquanto Coase (1960) mostrou que custos de transação interferem diretamente na alocação eficiente de recursos. Custos de transação têm influência direta sobre a evolução da economia e da 
sociedade, e instituições aprimorariam pontos chaves para o crescimento de mercados e mudanças na produção com as novas tecnologias, segundo North (1995). O autor aponta que a criação de um sistema efetivo de direitos de propriedade e outras regras e normas, formais e informais, permitiu a evolução dos mercados como mecanismos para a realização de trocas impessoais e coordenação dos esforços de indivíduos, bases para o progresso tecnológico e a produção moderna.

$\mathrm{O}$ ambiente institucional reage às alterações de estruturas de governança de transações no longo prazo, sendo as alterações das macroinstituições cruciais para a promoção da competitividade de sistemas de prestação de serviços. No entanto, a preocupação com o ambiente institucional está diretamente relacionada com o entendimento dos impactos de mudanças nas regras do ambiente institucional sobre o deslocamento de custos de governança de transações por estruturas distintas. Dentre as principais instituições, são apresentados os direitos de propriedade, a lei contratual e a reputação.

\subsubsection{Direitos de propriedade}

Um dos principais problemas na promoção do bem-estar e da eficiência econômica, como formulado por Coase (1960), refere-se a internalização dos danos de externalidades, que seriam efeitos das ações de um agente sobre o bem-estar de outro. O autor propôs que a definição clara de direitos de propriedade permitiria a criação de compensações para minimizar os problemas de externalidades. $\mathrm{Na}$ presença de externalidades, mercados organizados e competitivos podem não existir para a apropriação privada de custos e benefícios da produção e do consumo de bens, sendo esta uma das razões apontadas para a intervenção do Estado na atividade econômica com a regulamentação ou a produção de bens.

A regulamentação de atividades interfere na definição de direitos de propriedade, que segundo Eggertsson (1990), devem possuir três características essenciais: a primeira diz respeito ao direito de utilizar um ativo, inclusive transformá-lo fisicamente; a segunda refere-se ao direito de se apropriar da renda gerada por um ativo; a terceira versa sobre o direito de transferir o direito sobre a posse de sobre um ativo. 
A importância da definição desses direitos de propriedade e as garantias ao seu cumprimento foram objetos de estudos de Alchian (1961) e de Demsetz (1967), sendo que para este os direitos de propriedade representam um instrumento da sociedade que auxiliaria na formação de expectativas sobre o que conseguiriam nos acordos com outros indivíduos. O cálculo de benefícios e custos empreendidos por indivíduos ou grupos na luta pela definição dos direitos determinaria sua criação, que automaticamente serviria de base para o estabelecimento de compensações adequadas para danos de externalidades e capacitaria indivíduos a calcular os retornos de transações com outros indivíduos, permitindo o empreendimento de esforços na provisão de bens. A importância da propriedade privada ressaltada na literatura econômica recente, como em North (1994), é acompanhada da discussão sobre a necessidade de criar meios para a preservação de direitos adquiridos, pois a incapacidade de evitar a expropriação elevaria os custos de transação para todas as estruturas de governança. Williamson (1996) diferencia a expropriação do Estado, que comparativamente eleva os custos de transação de maneira equivalente entre estruturas de governança, da expropriação comercial, que atinge em maior intensidade estruturas híbridas e mercados.

\subsubsection{Externalidades}

Externalidades podem ser negativas, quando as ações de um agente causam prejuízos a terceiros outros, ou positivas, quando aos outros favorecem. A existência de mecanismos de segurança instalados em uma residência, por exemplo, pode desviar o interesse de praticantes de delitos para residências menos protegidas em uma vizinhança. Por outro lado, se o emprego de sistemas de segurança sofisticados é amplamente utilizado em uma vizinhança, uma casa sem tais recursos pode parecer tão protegida quanto, gerando externalidades positivas. A instalação de uma guarita em uma rua pode aumentar a segurança para proprietários que não financiaram a provisão do serviço, significando uma outra forma de externalidade positiva.

A existência de externalidades no policiamento é uma das principais razões para a regulamentação da atividade privada e a produção de serviços pelo Estado. O policiamento provido pelo setor público resolve parte do problema, atingindo indivíduos 
não defendidos pelo sistema privado. A regulamentação de atividades de investigação privada, por exemplo, pode ser fundamental para combater a invasão de privacidade.

\subsubsection{Bens públicos, quase públicos e privados}

A solução proposta por Coase (1960), de definição dos direitos de propriedade para internalizar os danos das externalidades não é possível nas situações em características de bens públicos são observadas nos ativos transacionados. Randall (1987) ressaltou que os mercados falham na provisão de bens públicos ou quase públicos devido à não-rivalidade e não-exclusividade no consumo. A não-rivalidade no consumo refere-se ao fato de a quantidade de um bem ou serviço não ser reduzida para a coletividade pelo consumo individual. Cobertos os custos de produção e disponibilizado o bem para a coletividade, o custo marginal de ofertar o bem para um indivíduo adicional seria nulo.

A não-exclusividade refere-se à condição de que o consumo de um bem não pode ser impedido a não ser a um alto custo, isto é, mesmo que alguns indivíduos não tenham contribuído para a produção ou aquisição do bem, não haveria um forte impedimento a seu consumo. O financiamento da produção desses bens pode não ser viabilizado, devido ao efeito "carona", como explica Randall (1987), em que os indivíduos esperariam os demais realizarem os esforços de produção para tirarem proveito do resultado.

Os bens que atendem parcial ou totalmente a pelo menos uma dessas características são chamados de bens públicos impuros. Stiglitz (1987) explicou que existe um continuum entre bens públicos puros e privados. Os bens públicos puros teriam custos de exclusão infinitos e não possuiriam rivalidade no consumo. Os bens privados possuiriam baixos custos de exclusão e elevado custo marginal de provisão. Bens quase-públicos estão entre esses extremos, com graus maiores ou menores de nãorivalidade e/ou não exclusividade. O Quadro 1 resume as características do bens públicos e quase públicos, segundo Stiglitz (1987). 


\begin{tabular}{|l|l|l|}
\cline { 2 - 3 } \multicolumn{1}{c|}{} & Rivalidade & Não-Rivalidade \\
\hline Exclusividade & Bens privados & Monopólios naturais \\
\hline $\begin{array}{l}\text { Não-Exclusividade } \\
\text { para membros de } \\
\text { clubes }\end{array}$ & Racionados & Não racionados \\
\hline Não-Exclusividade & & $\begin{array}{l}\text { Bens livres - Ofertados pela } \\
\text { natureza em abundância }\end{array}$ \\
\cline { 3 - 3 } & Bens mistos & Bens públicos puros \\
\hline
\end{tabular}

Quadro 1 - Características dos bens públicos e quase públicos

Fonte: adaptado de Stiglitz (1987)

A intervenção do Estado pode ser válida para controlar o uso dos recursos na presença dos bens públicos, evitando que a ação individual degrade a propriedade coletiva sobremaneira. Busca-se com o controle do acesso evitar o problema que Hardin (1968) apresentou como "a tragédia dos comuns", em que a utilização livre dos recursos comunitários levaria à apropriação individual de benefícios e a transferência de custos para a coletividade, em um nível de degradação que tenderia a ser maior que o desejado por toda a sociedade, causando sérios prejuízos ao bem-estar social.

Essencialmente, forçar o cumprimento de direitos de propriedade implicaria em assegurar a exclusão de indivíduos do consumo dos bens, como apontou Eggertsson (1990), com a coerção realizada pelo Estado ou pelos indivíduos. Os recursos humanos, instalações e equipamentos, providos para a produção da segurança, pelos setores público ou privado, têm a função de assegurar a exclusividade no consumo, propiciando aos indivíduos e grupos direitos efetivos de propriedade sobre bens ou serviços.

Uma categoria interessante de bens quase públicos está relacionada aos grupos de indivíduos que voluntariamente se associam para financiar sua oferta, os chamados "clubes", de acordo com Sandler (1995). As associações de indivíduos podem sustentar a provisão de bens com a característica de rivalidade, mas que até certo ponto permitam a exclusividade no consumo, por meio de algum mecanismo, dos que não fazem parte das associações. Os problemas de coordenação de indivíduos e grupos sociais para 
garantir a oferta de bens quase públicos através de clubes, no entanto, separam defensores do uso do mercado e do Estado na provisão desses bens.

Características de bens públicos aparecem em vários pontos de interesse sobre a discussão no sistema de prestação de serviços de segurança. Tanto os serviços de segurança, os bens protegidos e alguns instrumentos empregados na coordenação de agentes na cadeia podem ser afetados pelas características de bens públicos, o que se discute nas subseções a seguir.

\subsection{Serviços de segurança}

Dentre serviços de segurança, o exemplo mais claro de bem público seria a defesa nacional, um serviço que beneficia a todos os habitantes de um território. Pelo menos em determinados locais, o policiamento também pode ser caracterizado como um bem não-rival e não-exclusivo. Ao estabelecer uma patrulha em uma localidade, o ingresso de um indivíduo adicional a ser protegido não reduz, até certo ponto, a disponibilidade do policiamento para os demais membros, caracterizando a não rivalidade. Também é difícil excluir o indivíduo um indivíduos da melhoria na segurança de um ambiente comunitário, mesmo que este não tenha contribuído para a promoção da segurança.

Como ressalta Forst (2000), um processo político é estabelecido para assegurar a provisão de bens públicos, como é feito com os serviços estatais de segurança. O Estado provê segurança dentro de regras estabelecidas no processo político, constituindo um corpo policial que limita sua atuação aos parâmetros da lei.

Quando oferecido a um grupo de pessoas, os serviços de segurança privada também são oferecidos com certo grau de não-rivalidade aos membros de uma associação, participantes de eventos, membros de áreas comerciais, habitacionais e clubes. A provisão da segurança privada para coletividades, no entanto, depende de uma conjunção de interesses individuais não facilmente conseguida. 


\subsection{Espaços comunais}

Serviços de segurança são essenciais para assegurar a cobrança de ingressos em eventos, de pedágios em rodovias privadas, para garantir a qualidade do convívio em propriedades com áreas coletivas, como shoppings centers, clubes, prédios, condomínios, restaurantes e campi de universidades, dentre outros espaços freqüentados pelo público. O ressurgimento da segurança privada, segundo Kempa et al. (2004), deve ser interpretado como uma mudança nas relações entre propriedades, de forma que a propriedade privada torna-se provedora desses espaços comunais protegidos pelo policiamento privado. As alterações nas relações de propriedade, por sua vez, seriam fruto de mudanças mais amplas na política e na economia.

Shearing e Stenning (1992) apontaram como um dos motores do crescimento dos serviços privados a tendência de expansão de espaços de propriedade privada abertos ao público, um conceito que foi estendido por Kempa et al. (2004) para incorporar outras formas de espaços comunais. Para os autores, existe um continuum de novas formas de espaços comunais empregando a segurança privada, que vão de um extremo formado por propriedades do Estado abertas à visitação pública, passando por propriedades privadas abertas ao público, como imaginado por Shearing e Stenning (1992), até o extremo de espaço comunal formado por enclaves fortificados, como condomínios e clubes privativos, fechados para o público geral, mas abertos para os seus membros, estudados por Caldeira (2000).

A capacidade de exclusão é essencial em novas formas de provisão de espaços coletivos, podendo ser esta exclusão conseguida através de impedimentos de acesso, como nos condomínios, ou, como em shoppings centers, através de uma grande capacidade de monitoramento de indivíduos, que agiliza a reação às ocorrências de delitos e impede danos às propriedades. Estes tipos de espaços comunais apresentam um estatuto particular que atende a interesses específicos, diferentemente de locais públicos nas mãos do Estado. Ele estabelece um sistema de segurança disponível para todos os membros de uma coletividade, atendendo necessidades específicas com ganhos de escala. Nesses espaços monitorados, o fluxo livre de pessoas não traz grande ameaça às propriedades, tornando-os propícios ao desenvolvimento de transações. 
As implicações das transformações nas relações de propriedade em termos de segregação social e exclusão que afloram de processos políticos e econômicos não são aprofundadas neste texto. Contudo, a expansão da segurança privada com as novas formas de propriedades é mais um reflexo que a responsável por tais distorções. Segundo esses mesmos autores, diferentes níveis de análise estariam envolvidos na explicação de arranjos policiais que surgem, sendo necessário compreender a importância da globalização, das relações econômicas e políticas, das relações de propriedade e dos padrões locais de controle social para determinar formas de policiamento relacionadas com objetivos de defesa de valores democráticos, por exemplo, dentre outros objetivos.

\subsubsection{O efeito reputação}

Farina et al. (1997) destacam que a repetição de transações possibilita a redução da assimetria de informações entre participantes de jogos, permitindo o conhecimento das idiossincrasias de partes e tornando o resultado de uma transação mais previsível. Os autores sustentam que a reputação sobre um indivíduo é formada nesta interação, e por interferir em resultados de transações futuras, funciona como uma restrição ao oportunismo dos agentes. Além disso, considera-se que a reputação de um indivíduo reduz os custos de obtenção de informações sobre os produtos que este negocia, sendo formada por um conjunto de conhecimentos sobre determinada pessoa ou organização, que inclui experiências sobre o consumo da produção anterior do indivíduo. Segundo Machado (2002), a reputação aumenta a quantidade de informação disponível no instante da concretização da transação, servido como uma garantia de que promessas sobre determinadas características do bem ou serviço transacionado são verificadas de maneira consistente ao longo do tempo. A reputação assume um papel especialmente importante no caso de bens de crença, ou seja, bens cujos atributos de qualidade não podem ser observados mesmo depois de sua aquisição. A assimetria de informações, determinante da incerteza, e a freqüência, são atributos necessários para que o efeito reputação seja representativo nas transações. 
A reputação, como Machado (2002) ressalta, é formada através de um processo dinâmico, associado com investimentos na marca comercial, em certificados e em relações de longo prazo. Na transação de bens de alta qualidade com atributos não observáveis, a construção da reputação requer inicialmente que o produto seja comercializado com preços abaixo dos custos, devendo, no entanto, existir um preço prêmio que compense o investimento inicial. A reputação envolve um processo de controle de qualidade, que aumenta os custos de transformação, tornando-se viável quando o investimento na sua criação é recompensado pela redução dos custos de transação. $O$ investimento na construção da reputação é bastante elevado para ser realizado por indivíduos, sendo mais acessível para empresas. Riley (2001), argumenta que é mais barato sinalizar a qualidade produtos individuais sob a reputação das firmas.

A boa ou má reputação de um agente afeta as possibilidades de repetir transações com um parceiro atual ou indivíduos a ele relacionados. A presença de uma rede de comunicação entre agentes é essencial para garantir a difusão de informações sobre um indivíduo, como observam Milgrom e Roberts (1992), tornando o efeito reputação expressivo.

A reputação interfere diretamente nos custos de transação de formas híbridas, na qual o oportunismo pode aumentar custos na elaboração de contratos. A boa reputação de um agente ameniza a necessidade de elaboração de contratos complexos em formas híbridas, diminuindo assim os custos de transação.

\subsubsection{Leis contratuais}

Os termos de um contrato estão sujeitos a um regime contratual e a arbitragem de cortes, interferindo diretamente nos custos de governança. Especialmente no caso de formas híbridas, as leis contratuais têm um amplo efeito, reduzindo custos de transação quando interferem na possibilidade de comportamento oportunista dos agentes. Uma doutrina sobre regimes contratuais, como WillIamson (1996) declara, não deve ser muito rígida, de forma a prejudicar a solução de disputas com eventos não antecipados, nem muito frouxa, ao ponto de prejudicar a aplicação de termos contratuais estabelecidos. A 
legislação mais clara pode reduzir a incerteza e tornar os custos de transação de formas híbridas menores, incentivando o investimento em ativos específicos.

Os custos de hierarquias podem ser aumentados se as cortes interferirem na solução de disputas sobre assuntos técnicos, criando desvantagens desta em relação àS formas híbridas de relação.

\subsection{Estruturas de governança}

Como Machado (2002) explica, as formas de mercado, híbrida e hierárquica diferem com relação aos atributos de incentivo, controle e capacidade de adaptação. Os incentivos são diretamente relacionados com a receita líquida apropriada pelo participante da transação. $\mathrm{O}$ controle representa o suporte necessário para a implementação de planos estratégicos, coleta de informações e avaliação de desempenho entre as partes. A adaptação representaria a capacidade de reação à perturbações no meio ambiente, existindo uma adaptação autônoma, via mercado e reagindo a mudanças nos preços, e uma adaptação cooperativa, em que mecanismos são criados para coordenar as ações dos agentes.

Tomando as estruturas de governança como variável endógena e como variáveis exógenas os atributos de incerteza, freqüência e especificidade de ativos, o ambiente institucional e o comportamento individual de oportunismo e a racionalidade limitada, Williamson (1985) propôs que a estrutura de governança escolhida seria a minimizadora dos custos de transação. $\mathrm{O}$ atributo chave foi especificidade de ativos, que introduz a necessidade de adaptações às mudanças imprevistas quando eleva-se, tornando estruturas de governança com poderes de decisão maiores as mais capazes de proverem adaptações requeridas. Cada estrutura possui uma função custo particular:

$M=M(k, \theta)$, é o custo de governança via mercado.

$X=X(k, \theta)$, é o custo de governança via forma híbrida.

$H=H(k, \theta)$, é o custo para a governança hierárquica.

onde $k$ a especificidade de ativos e $\theta$ representa um vetor de deslocamento sobre dos custos de governança, incorporando variáveis do ambiente institucional, da freqüência e da incerteza nas transações. 
Assumindo que: $M(0)<X(0)<H(0)$, têm-se que a um baixo nível de especificidade os mercados são mais eficientes que formas híbridas e essas mais eficientes que formas hierárquicas. Assumindo também que $M^{\prime}>X^{\prime}>H^{\prime}$, têm-se em contrapartida que os mercados perdem eficiência para formas híbridas e hierárquicas com o crescimento da especificidade de ativos, que exige maior capacidade de adaptação cooperativa às situações imprevistas em acordos iniciais, conforme mostra a Figura 11 .

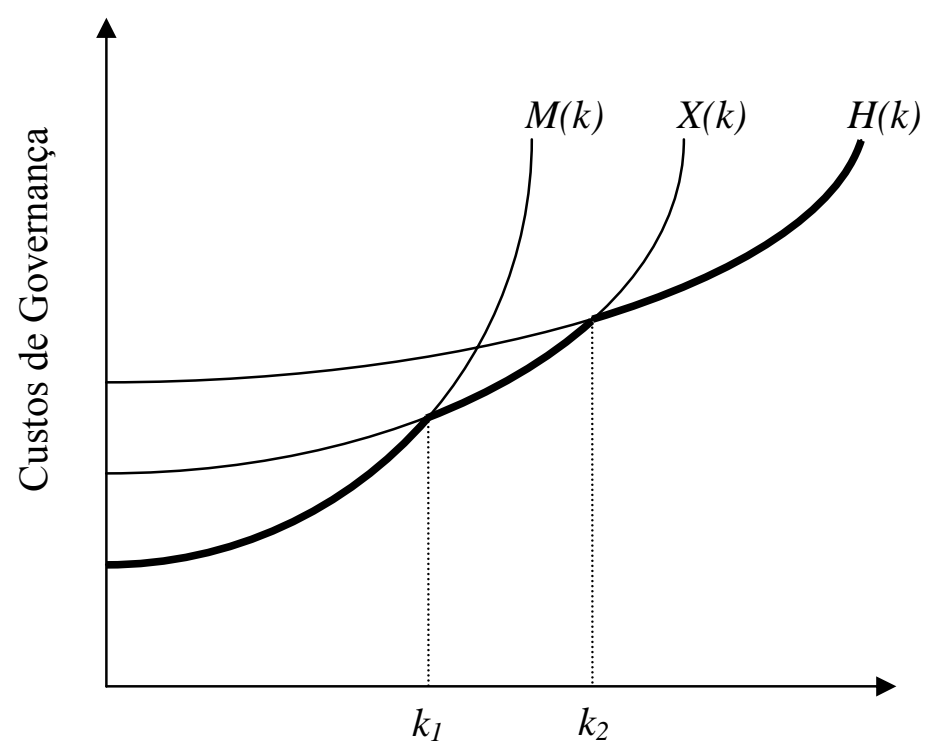

Especificidade de ativos

Figura 11 - Custos de governança de transações de arranjos institucionais distintos em função da especificidade de ativos.

Fonte: Williamson (1996)

Vining e Globerman (1999) construíram uma estrutura analítica para análise dos processos de terceirização com base nos atributos das transações. Para os autores, a combinação de baixa especificidade de ativos com baixa complexidade dos produtos e serviços ou de atividades desenvolvidas em algum processo formariam a circunstância ideal para a terceirização. A terceirização nesses casos ofereceria um potencial para redução dos custos de produção dos bens e apresentaria pequenos custos de transação. As firmas que terceirizassem serviços conseguiriam especificar com clareza termos 
contratuais, com baixa incerteza sobre as características de preços e performance. As firmas enfrentariam pequenos problemas com o oportunismo pós-contratual, pois poderiam substituir facilmente prestadores de serviços devido à baixa especificidade de ativos.

\subsection{O problema da assimetria de informações no mercado de trabalho}

Para explicar o comportamento do mercado de trabalho, essencial nos serviços de segurança privada, a primeira abordagem que a teoria econômica disponibilizaria seria de orientação neoclássica, na qual a oferta de trabalho seria estabelecida a partir de escolhas entre trabalho e lazer que maximizassem o bem-estar dos indivíduos. O lazer geraria bem-estar diretamente, mas as pessoas estariam dispostas a sacrificá-lo pelo trabalho se a remuneração obtida permitisse a aquisição de bens e serviços que compensassem a perda de utilidade com o trabalho. Maiores remunerações permitiriam maior aquisição de bens e serviços e melhoria do bem-estar, aumentariam a disposição dos indivíduos em renunciar ao lazer pelo trabalho até o ponto em que a elevação da remuneração não fornecesse um estímulo muito grande à aplicação de mais tempo ao lazer. Contudo, as firmas tomariam a decisão de contratação da mão-de-obra visando lucro numa relação tecnológica bem estabelecida entre fatores de produção e produtos. O nível de produção da firma e de emprego envolveria uma escolha de maximização de lucros que seguiria a regra de que o nível de produção ótimo seria aquele em que o salário real do trabalhador iguala-se ao valor do produto marginal. Pressupõe-se que o produto marginal seja decrescente, ou seja, mantidos outros fatores de produção constante, cada nova unidade de trabalho empregada gera um acréscimo de produção menor que a anterior. Neste enfoque neoclássico, aumentos nos salários reais seriam justificáveis apenas se houvessem avanços tecnológicos que tornassem trabalhadores mais produtivos.

A segunda abordagem sobre o funcionamento do mercado de trabalho adviria da teoria do capital humano que, assim como a teoria neoclássica, considera a remuneração dos trabalhadores estabelecida por sua produtividade marginal. As características possibilitam a diferenciação dos indivíduos, como sua inteligência, suas habilidades, sua 
saúde e diferenciais adquiridos por meio da educação, por exemplo, que potencialmente aumentaria sua produtividade. Um trabalhador incorreria em custos para se aperfeiçoar assim que formasse uma expectativa favorável quanto aos rendimentos futuros que obteria com tal esforço.

Uma terceira abordagem preocupar-se-ia com os problemas relacionados à assimetria de informações sobre atributos dos trabalhadores. Os estudos do mercado de trabalho, como ressalta Eggertsson (1990), formam um campo separado dentro da teoria econômica em função da impossibilidade de separar os proprietários do trabalho de seu capital humano. Os problemas relacionados com o comportamento oportunista estariam presentes em todos os mercados, mas no caso do mercado de trabalho seriam relevantes porque os incentivos para trabalhar para terceiros tenderiam a ser fracos. Do ponto de vista do trabalhador, afirma o autor, a relação de emprego envolveria uma escolha multidimensional em torno de rendimentos, condições de trabalho, localização e outros fatores. Do ponto de vista da firma, o trabalho recebido teria dimensões relacionadas com a duração, a intensidade e a qualidade do esforço, resultando em custos elevados para mensurar e forçar o cumprimento dos contratos.

Como os atributos relacionados ao caráter e a competência de um trabalhador não são diretamente observáveis, durante um intervalo de tempo os serviços deveriam ser contratados para terem seu valor atribuído. Os serviços são bens de crença, como propõe Nelson (1970), sendo seus atributos de qualidade não observados diretamente mesmo após o consumo. Ao contrário, segundo o autor, existiriam os bens de pesquisa, cujos atributos de preço e qualidade seriam reconhecidos antes de realizada a transação. De acordo com Vining e Globerman (1999), não compete estudar a influência do processo de terceirização em casos de bens de pesquisa, pois a aquisição representaria uma avaliação direta pelas firmas.

A assimetria de informações ocorre quando uma das partes envolvidas em uma transação possui informações relevantes que outra não possui, caso típico do mercado de trabalho. O trabalho de Akerlof (1970) foi pioneiro na análise da falha do mercado na condução de transações diante de informações assimétricas sobre a qualidade dos bens e serviços. A impossibilidade de definição adequada da qualidade dos produtos levaria o 
equilíbrio de mercado a ser estabelecido como preços inferiores, excluindo da oferta os produtos de maior qualidade. Teoricamente, a assimetria de informações poderia distorcer tanto as transações conduzidas pelo mercado que este simplesmente deixaria de existir. A aplicação deste argumento em análises de mercados é comum, como destaque para os mercados de seguros, de crédito e de trabalho.

No Brasil, Camargo (2002) utiliza o modelo para estudar os danos da assimetria de informações sobre o emprego de trabalhadores semi-qualificados, devido à dificuldade desses revelarem seus atributos aos empregadores. Quanto maior fosse a diferença no nível de informação sobre os atributos de qualidade de bens e serviços transacionados, maior seria o problema para a realização de transações. O modelo utilizado pelo autor para indicar os problemas trazidos pela assimetria de informações é apresentado no Anexo A.

A conseqüência do modelo é que o desemprego tende a ser grande quando os empregadores não conseguem distinguir a produtividade dos trabalhadores e oferecer salários compatíveis com as características individuais, caso agravado quando as instituições existentes no mercado de trabalho perturbassem a transmissão de informações entre trabalhadores e empregadores.

Um volume considerável de transações econômicas, conforme Spence (1975), é realizado através de pessoas com informações imperfeitas e diferenciadas, tornando importantes para as transações as informações de natureza diferente das presentes nos preços. Os mercados, segundo o autor, envolveriam processos de classificação e adequação de produtos através de redes, sinalização e filtragem de informações não relacionadas com preços. Para o autor, os indivíduos realizam transações repetidamente como um meio de prover incentivos para a sinalização crível de informações referentes a outros atributos. Segundo Spence (1975), a principal distinção entre firmas e mercados é que as primeiras são estruturas hierárquicas e de decisão centralizada, que viabilizam os processos de gestão que melhor controlam a alocação de recursos, enquanto os mercados são estruturas descentralizadas que estimulam a eficiência através da competição. $O$ problema da assimetria de informações não impediria que transações fossem realizadas, porque os empregadores buscariam informações sobre os trabalhadores e esses tentariam 
diferenciarem-se dos demais participantes do mercado. Para superar as falhas de mercado existiriam os mecanismos de a sinalização e a filtragem (screening).

A importância do mecanismo de sinalização como meio de corrigir falhas de mercado na presença de informação assimétrica foi primeiramente proposta por Spence (1973), analisando o mercado de trabalho tanto pelo fato de existir informação assimétrica quanto pela freqüência das transações serem pequenas entre um trabalhador e outros empregadores, o que justificaria uma análise considerando a reputação do trabalhador. Em seu trabalho, o autor declarou ser a sinalização um conjunto de informações apresentadas por um agente para convencer outra parte de seus atributos. Se escolaridade e aptidão para o trabalho fossem associadas, indivíduos poderiam diferenciarem-se dos demais no mercado e conseguirem melhores colocações.

Por outro lado, os departamentos de recursos humanos das empresas deveriam ser hábeis em conseguir diferenciar indivíduos. Do ponto de vista de quem toma iniciativa para obter informações, o processo de filtragem (screening) seria uma função dos departamentos de recursos humanos das empresas, como destacou Camargo (2002), que buscariam obter informações, de maneira custosa, sobre os atributos dos indivíduos. Este custo pode atingir tanto grandes empresas, que desperdiçariam recursos na busca de informações, quanto as menores, que não conseguiriam manter um departamento de recursos humanos adequado e que obteriam informações por tentativa e erro. Além do desemprego, que poderia aparecer no mercado de trabalho com informação assimétrica, uma alta rotatividade de mão-de-obra e um baixo incentivo para investimento em qualificação e treinamento, tanto por trabalhadores quanto por empresas.

Lazear (1995) mostra que as firmas realizam a filtragem dos trabalhadores adquirindo informações privadas sobre indivíduos. Este tipo de informação permitiria truncar uma distribuição de trabalhadores contratados, permitindo à firma reduzir a variância e aumentar a média da distribuição dos indivíduos pelo valor que esses adicionariam ao processo produtivo da firma. O autor argumenta que indivíduos do sexo masculino possuem variância maior em vários tipos de medições de resultados, como testes de QI, de rendimentos recebidos, testes de performance, teste de proficiência em escrita, leitura e matemática. O autor argumenta, no entanto, que nesses casos de alta 
dispersão, como apresentado na distribuição de probabilidades B na Figura 12, informação privada suficiente pode ser adquirida e a parte de valores inferiores poderia ser cortada com a eliminação dos indivíduos com menor potencial para adicionar valor aos processos produtivos. A informação privada permitiria, neste caso, aumentar a média da distribuição e diminuir a dispersão de valores. A aquisição de informações privadas para truncar a distribuição de valores seria a razão pela qual as firmas aplicariam recursos na filtragem de trabalhadores.

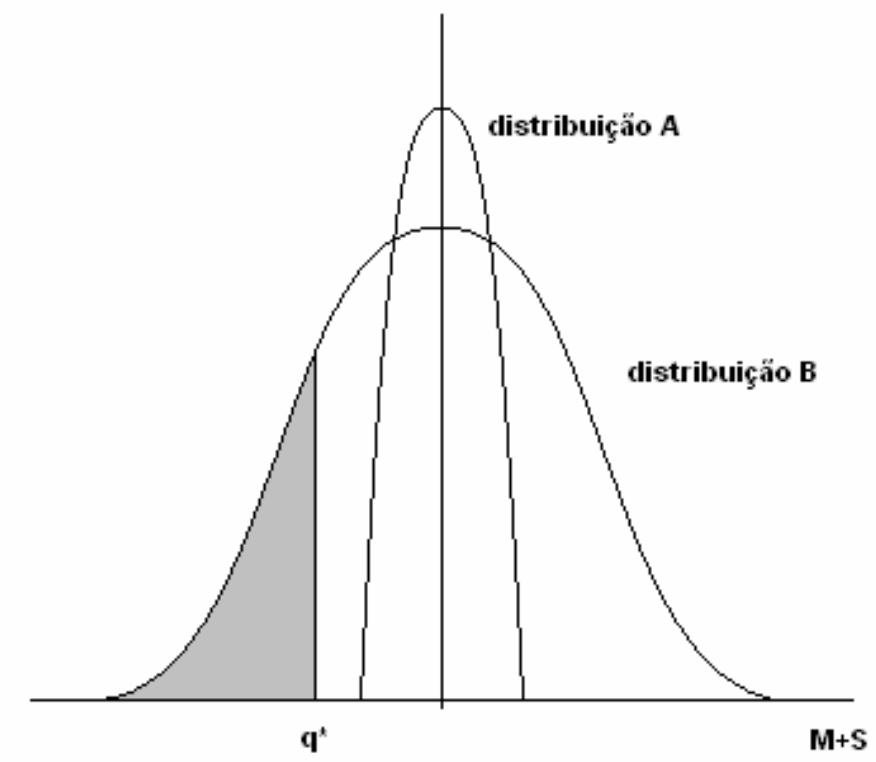

Figura 12 - Distribuição de probabilidades dos valores dos trabalhadores Fonte: Lazear (1995)

Conforme Camargo (2002), as instituições no mercado de trabalho poderiam gerar incentivos aos agentes que prejudicariam os mecanismos de sinalização e, conseqüentemente, as relações de trabalho. Com os problemas de assimetria de informações e seleção adversa, as instituições deveriam ser analisadas no sentido da influência sobre o comportamento dos indivíduos revelarem informações privadas confiáveis. Instituições comumente encontradas em países da América Latina, segundo Camargo (2002), poderiam atrapalhar a solução de problemas causados pela assimetria de informações, ao protegerem trabalhadores nos momentos de demissões ou de 
reduções de salário. $\mathrm{O}$ estímulo às demissões pelo pagamento de indenizações, como cita o autor, induziria a rotatividade da mão-de-obra e diminuiria a transparência do mercado de trabalho.

\subsection{Salário de eficiência e incentivos}

A questão de incentivos na prestação de serviços de segurança é tratada seguindo a idéia do salário de eficiência. Nesta abordagem inverte-se a relação de causalidade entre a produtividade e o salário do trabalhador. Segundo Milgrom e Roberts (1992), salários de eficiência seriam empregados em lugar de pagamentos de incentivos se esses fossem inviabilizados tanto em função de o empregado não transmitir sinais claros de suas características quanto por não existirem meios objetivos de avaliação da performance do trabalhador. Além deste fato, os autores sustentam que esta prática evitaria o problema do oportunismo do empregador em distorcer avaliações de performance e prejudicar os empregados, além de reduzir o problema da seleção adversa.

De acordo com Katz (1986), os altos salários ajudariam na redução da rotatividade, estimulariam a produtividade, preveniriam ações coletivas, atrairiam bons trabalhadores, melhorariam o trabalho de equipe e o sentimento de lealdade pela firma. $\mathrm{O}$ autor indica que modelos nesta linha podem explicar o desemprego involuntário, a segmentação no mercado de trabalho e os diferenciais de salários entre firmas e entre indústrias, para trabalhadores com características produtivas semelhantes. A determinação da produtividade pelos salários ficaria evidente com o comportamento persistente das firmas em pagarem salários superiores ao de mercado, situação que tende a permanecer mesmo com a existência de uma oferta expressiva de trabalhadores dispostos a receber baixos salários.

Stiglitz (2000) indica que a idéia de salário de eficiência foi antecipada pelo economista Alfred Marshall, sendo que Leibenstein (1957) formulou esta hipótese acreditando numa forte ligação entre salários e os aspectos nutricionais e de saúde de trabalhadores em países pobres. Shapiro e Stiglitz (1984) desenvolveram um modelo em que o desempenho do trabalhador não pode ser monitorado ou supervisionado sem 
custos, podendo este permanecer ocioso durante o tempo de trabalho. Se as firmas pagassem o salário de mercado para todos os trabalhadores e esses possuíssem as mesmas características, haveria pleno emprego. Dada a estrutura de remuneração comum a todos, pelo salário de mercado, a dedicação às atividades produtivas cairia, sem que houvessem danos para a reputação de trabalhadores lenientes e gerando uma tendência de ociosidade generalizada. As firmas combateriam a ociosidade aumentando os salários pagos e reduzindo o volume de empregos gerados.

O desemprego aumentaria o custo de oportunidade do posto de trabalho, criando incentivos para o trabalhador manter-se ocupado, como aponta Stiglitz (1974), gerando uma postura de luta para preservar seu posto de trabalho. A redução da negligência no trabalho e a luta para manter alta sua produtividade fariam com que o trabalhador produzisse mais, aumentado o lucro do empregador.

Milgrom e Roberts (1992) ressaltam a abordagem em um grupo de questões relacionadas com a provisão de incentivos adequados aos indivíduos, capazes de promoverem eficiência e os interesses das firmas. Mesmo em países desenvolvidos, os autores destacam que os salários mais elevados poderiam também viabilizar a aquisição de alimentos mais saudáveis e nutritivos, dando mais energia para trabalhares e aumentando sua produtividade.

Milgrom e Roberts (1992) apresentam uma simplificação do modelo de Shapiro e Stiglitz (1984) de salário de eficiência, que expressa a formulação relacionada com o incentivo do comportamento honesto, especialmente importante em organizações como um corpo policial. A primeira pressuposição nesta formulação é que o único meio para disciplinar o comportamento dos empregados seria a demissão. Os incentivos percebidos para manter o comportamento dentro das regras de conduta dependeriam do retorno obtido com o comportamento inadequado, que os autores denotam por $g$; do número de períodos em que a relação de trabalho pode ser repetida, ajustado pela taxa de juros, que resulta no multiplicador $N$; da probabilidade de ser detectado o comportamento desonesto, denotada por $p$; do salário oferecido pelo empregador atual, $w$; e da oportunidade de remuneração que o empregado poderia encontrar alternativamente $\bar{w}$. Este valor $\bar{w}$ já estaria descontado do custo de buscar um novo trabalho, do período de 
desemprego durante a busca e do custo de participar de processos de seleção, dentre outros fatores. A decisão de agir de maneira desonesta seria tomada sempre que $g>p(w-\bar{w}) N$.

O valor $w-\bar{w}$ representa uma renda para o trabalhador no sentido do excedente que recebe na ocupação atual e sobre outras oportunidades existentes. O trabalhador tende a evitar a demissão e garantir este excedente quanto maior fosse a expectativa de que a relação de trabalho seria prolongada, aumentando diretamente o multiplicador $N$. Da relação acima, infere-se que o comportamento honesto do trabalhador pode incentivado diretamente pelos contratantes, com a aplicação de recursos no salário pago $w$ ou em monitoramento, que aumenta a probabilidade de detectar o comportamento desonesto, $p$.

Além desta atuação direta das firmas, os autores assinalam que o conjunto de relações sociais pode tornar imprescindível a boa reputação de um trabalhador na obtenção de rendimentos. Trabalhadores com reputação negativa entre empregadores poderiam ter as possibilidades de remuneração alternativa, $\bar{w}$, substancialmente reduzidas por deixarem de ser reempregados na empresa atual e nas empresas que façam parte do grupo de relações sociais do empregador. Ademais, os autores ressaltam a perda de oportunidades de trabalho como um fator que diminui o multiplicador $N$ sobre o excedente de renda que o trabalhador recebe.

Como observam Milgrom e Roberts (1992), esta representação não implicaria que considerações sobre ética e moralidade não interfiram diretamente nas decisões dos trabalhadores de comportarem-se de maneira honesta ou não. Decisões reais dos indivíduos sobre infringir ou não regras iriam além do simples cálculo de custos e benefícios representados na regra de decisão acima. Com a ambigüidade das idéias de certo ou errado e os benefícios que podem ser obtidos com a infração de regras, mesmo trabalhadores honestos estariam tentados a se comportar de maneira inadequada. Além da não infração de regras, a negligência no trabalho estaria inversamente relacionada com o excedente recebido pelos trabalhadores. A provisão de um salário suficientemente elevado, a detecção e a punição por infrações impediriam a propagação de 
comportamentos desonestos entre os empregados, o que seria fundamental para o desempenho da empresa que baseasse seus negócios na honestidade dos trabalhadores.

Esteves (2002) estabeleceu uma expressão para o custo de oportunidade do emprego com a inclusão da possibilidade de recebimento do seguro desemprego, caso os trabalhadores permanecessem desempregados durante algum período. Os trabalhadores estariam comparando o salário real que recebem em determinada ocupação com o rendimento que esperariam receber ao deixá-lo, dado pela ponderação de salários poderiam receber em uma atividade alternativa, se encontrassem empregos, ou do valor do seguro desemprego se permanecerem desempregados. Assim, segundo Esteves (2002), o custo de perda do emprego seria:

$$
\omega^{e}=\omega-\left[(1-u) \omega^{a}+u \omega^{u}\right]
$$

onde:

$\omega^{e}$ é o custo de perder o emprego;

$\omega^{e}$ é o salário real recebido;

$\omega^{a}$ é o salário alternativo se, ao ser despedido, o trabalhador for empregado imediatamente;

$\omega^{u}$ é o seguro desemprego e $u$ a taxa de desemprego da economia.

Esta equação mostra que o seguro desemprego pode interferir diretamente na decisão de deixar o emprego, pois reduz seu custo de oportunidade.

Esta argumentação sustenta a visão de que as empresas de segurança privada podem criar incentivos para estimular trabalhadores a comportarem-se de maneira honesta se praticarem uma política de salários acima da alternativa de ocupação para o trabalhador. Dentre a justificativa do emprego do salário de eficiência, como um recurso importante para a promoção do esforço, estaria também a idéia de fortalecer o espírito de equipe entre os empregados, evitando uma visão de prática de salários injustos entre indivíduos, que prejudicaria o empenho dos trabalhadores. 
A existência de desempregados não exerceria forte pressão para queda dos salários reais, pois as remunerações destinar-se-iam primordialmente a incentivar um determinado comportamento e evitar custos com a substituição de trabalhadores, que se elevaria quanto maior fosse a aptidão e a adequação dos trabalhadores às funções específicas do posto de trabalho. De acordo com Milgrom \& Roberts (1992, p.254) o emprego do salário de eficiência não implicaria o abandono do monitoramento pelas firmas. Existiria uma escolha ótima de monitoramento em função da probabilidade de detecção de fraudes, um problema de minimização que os autores apresentam como:

$$
\begin{aligned}
& \operatorname{Minimizar} M(p)+w \text { sujeito a } p(w-\bar{w}) N \geq g \\
& \quad p, w
\end{aligned}
$$

onde:

$M(p)$ é o custo de monitoramento dos empregados com probabilidade $p$ de impedir fraudes, em qualquer período de tempo;

$w$ é o salário do funcionário pago no seu emprego atual;

wé o salário que o empregado obteria se ele procurasse outro trabalho no mercado após ser demitido do emprego atual;

$w-\bar{w}$ é a renda do funcionário no emprego;

$N$ é o multiplicador que expressa valor de longo prazo na relação entre empregado e empregador;

$g$ é a quantia que o empregado deveria ganhar por cometer fraudes no trabalho.

Deste problema de implementação do custo mínimo para a firma, na tentativa de reduzir fraudes, a obtenção da solução ótima para o salário seria representada por:

$$
w=-\bar{w}+\frac{g}{N p}
$$

Ao substituir a eq. (3) na função objetivo, eq.(2): 
$\operatorname{Minimizar} M(p)+\bar{w}+\frac{g}{N p}$

$p$

A solução ótima desse problema $\left(p^{*}\right)$ será obtida a partir das eq.(5) e (6), que se referem, respectivamente, à primeira derivada em relação à p igual à zero e à segunda derivada não-negativa:

$$
\begin{aligned}
& 0=M^{\prime}\left(p^{*}\right)-\frac{g}{p^{* 2} N} \\
& 0 \leq M^{\prime \prime}\left(p^{*}\right)+\frac{2 g}{p^{*^{2}} N}
\end{aligned}
$$

A probabilidade ótima $\left(p^{*}\right)$ pode ser visualizada graficamente, por meio da Figura 12. A expressão $M^{\prime}\left(p^{*}\right)$ indica como o salário eficiência ótimo se altera à medida que probabilidade de impedir fraudes $(p)$ se eleva. A expressão $\left(-\frac{g}{p^{*^{2}} N}\right)$ indica que há redução nos custos de monitoramento à medida que probabilidade $p$ aumenta. Neste caso, nota-se que há diminuição no valor de $p$ com o aumento de $N$. 


\section{Valor monetário (\$)}

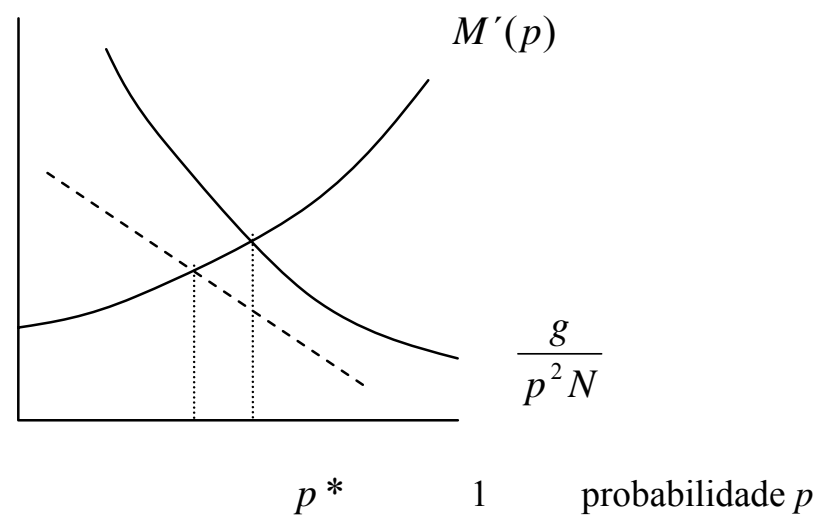

Figura 13 - Probabilidade ótima de fraude $\left(p^{*}\right)$

Fonte: extraído de Milgrom \& Roberts (1992)

\subsection{A expansão da segurança privada}

Antes da organização do policiamento público, ao longo da história, os recursos privados promoveram a segurança das propriedades e dos indivíduos, como afirma Forst (2000). Segundo o autor, a organização do policiamento por indivíduos e grupos está diretamente relacionada com a eficiência da segurança provida pelo policiamento público que, dentre outras causas, diminuiu pelo distanciamento entre a polícia e a comunidade protegida. $\mathrm{O}$ autor atribui à especialização e a profissionalização do corpo policial o motivo deste distanciamento. Apesar de contribuir parcialmente para a eficiência na prestação de serviços, a especialização e a profissionalização das forças policiais seria responsável por um clima de arrogância e superioridade da força policial sobre os cidadãos comuns, criando bases para um comportamento agressivo e insensível aos apelos populares.

A resposta privada para a incapacidade da polícia pública atender efetivamente às demandas com o aumento da criminalidade, bem como a dificuldade de organização e envolvimento de comunidades para a promoção da segurança, deixariam abertas as 
oportunidades para organização de recursos físicos e humanos pela iniciativa privada. Como Forst (2000) indica, o florescimento da segurança privada complementaria o policiamento público na provisão de serviços especializados, sendo que sua expansão ocorreria tanto pelo emprego individual quanto pela criação privada de espaços e serviços para uso coletivo. Bayley e Shearing (2001) afirmam que o policiamento está sendo reconstruído em termos globais, sendo que dentre as principais características da transformação encontram-se:

1) A separação entre quem autoriza o policiamento e quem o realiza, além da transferência de funções de autorização e execução do governo;

2) A mudança no policiamento não deve ser entendida simplesmente como privatização, em função da dificuldade de distinção entre os domínios público e privado;

3) É preciso entender distintamente a forma como o policiamento é autorizado da maneira como é realizado;

4) O policiamento é autorizado sob cinco auspícios: interesses econômicos legais ou ilegais; comunidades residenciais; comunidades culturais; indivíduos e governos;

5) O policiamento é provido por empresas, indivíduos e governos;

6) Muitos provedores não governamentais agora executam as mesmas tarefas que o policiamento público;

7) Embora executem as mesmas tarefas, empregam práticas distintas. O policiamento fornecido pelo setor público previne crimes através da punição, enquanto o policiamento fornecido pelo setor privado previne crimes através da exclusão e controle de acesso;

8) O policiamento público tem mudado sua atuação, especializando-se em investigação e segurança em espaços não cobertos por sistemas de segurança;

9) As explicações para a atual reestruturação do policiamento envolvem idéias sobre o policiamento público, aumento na criminalidade, a natureza do sistema econômico e do governo, estruturas sociais, idéias e cultura; que são explicações amplamente hipotéticas, com pouca pesquisa empírica para testar ou confirmá-las;

10) Os governos devem preservar a justiça, a igualdade e a qualidade dos serviços na atual reestruturação do policiamento; 
11) Para salvaguardar os interesses públicos no policiamento, o governo deve desenvolver a capacidade de regular, auditar e facilitar a reestruturação do policiamento.

Para Bayley e Shearing (2001) a função do governo como provedor da segurança é dúbia, porque esse passa a assumir a identificação do tipo de segurança necessária e a garantir os meios de alcançar os níveis desejáveis de serviços. Na visão dos autores, a reestruturação do policiamento deveria incluir a separação das funções de autorização da execução dos serviços de segurança, abrindo espaço para a atuação de grupos de interesses, indivíduos e governo no exercício dessas funções.

\subsection{A reformulação do policiamento público}

Além da resposta privada, Trojanowicz e Carter (1988) indicam que existem propostas de reformulação dos serviços do setor público, tais como o policiamento comunitário, que seria uma filosofia de policiamento pró-ativo e descentralizado para controlar o crime e a desordem.

Segundo esses autores, considera-se que agentes e a comunidade devem estar envolvidos em uma relação de confiança para aumentar a cooperação entre si, transmitindo informações e fornecendo assistência mútua para o alcance de objetivos ligados ao bem comum. O fluxo de informações deve ser incrementado para que indivíduos sejam "os olhos e ouvidos" do policiamento e para ajustar os objetivos do policiamento aos interesses da comunidade em que estão instalados. Os autores afirmam que o policiamento comunitário não deve estar atrelado aos interesses de indivíduos ou grupos específicos, e sim aos interesses de todos os membros de uma comunidade, focalizando áreas de maiores ocorrências. O policiamento não seria especializado em algumas funções, que nos Estados Unidos levou à perda de percepção e de capacidade de adequação às necessidades específicas de comunidades. Deveria ser um policiamento organizado em função de diagnósticos sobre determinada vizinhança, envolvendo indivíduos nos objetivos de combate ao crime.

Cabe explorar, dentro da concepção de policiamento comunitário, a integração entre agentes de segurança pública e privada. Principalmente através da troca de 
experiências e transmissão de informações a efetividade do sistema de segurança como um todo pode ser incrementada. 


\section{MATERIAL E MÉTODOS}

Este capítulo descreve a fonte de dados utilizada na condução deste estudo e apresenta os métodos propostos para a sua análise.

\subsection{Fonte de dados}

$\mathrm{Na}$ composição desta pesquisa foram utilizados dados de um questionário, apresentado no Anexo B, que aborda aspectos importantes do perfil de empresas de segurança privada relacionados à política de remuneração e à contratação de vigilantes.

Segundo os dados da PNAD (2002), avaliando a distribuição do número de vigilantes por estado, para o Brasil, verifica-se que o estado de São Paulo é o que concentra um maior percentual, de 27\%, seguido pelo Rio de Janeiro, com 13\%. A presente pesquisa restringe-se à cidade de São Paulo, considerando-se o elevado percentual da categoria no estado, e por se tratar de importante centro econômico e populacional, com sérios problemas de segurança, que levam ao emprego intensivo de segurança privada.

\subsection{Procedimento de aplicação do questionário}

Inicialmente, realizou-se um pré-teste com 8 empresas, que foram entrevistadas na EXPOSEC - INTERNATIONAL SECURITY FAIR, uma feira voltada ao setor de segurança privada realizada no Centro de Exposições Imigrantes em São Paulo, de 18/5/2004 a 20/5/2004. Esse pré-teste ajudou a identificar a necessidade de ajustes no questionário formulado, particularmente para eliminar redundâncias e melhor contemplar os objetivos da pesquisa. 
Diante da restrição orçamentária e temporal de coletar as informações de todas as empresas, optou-se por obter amostra aleatória probabilística, composta por 30 empresas. O procedimento de amostragem permitiria que as características da região escolhida para análise fossem reveladas, sendo importante destacar, no entanto, que gera-se a possibilidade de ocorrer um viés proveniente da falta de resposta, conforme relatado por Pino \& Caser (1984). Em função da disponibilidade da pessoa a ser entrevistada, optou-se por realizar entrevistas pessoais ou enviadas por e-mail. O universo pesquisado compreende 237 empresas na cidade de São Paulo, ligadas à prestação de serviços de segurança patrimonial. A distribuição dessas empresas pelas zonas da cidade é apresentada na Figura 13 a seguir.

A amostra selecionada incluiu 30 empresas de segurança privada na cidade de São Paulo. Membros de cinco empresas negaram-se a participar da pesquisa, com receio do uso que seria feito da informação. Em onze empresas os entrevistados alegaram não dispor de tempo para realizar as entrevistas durante no período de coleta dos dados, sendo que seis dispuseram-se, a princípio, a responder o questionário enviado por email. Contudo, não houve retorno desses questionários mesmo com contato posterior solicitando a resposta. Foram realizadas dezoito visitas a empresas de segurança privada, sendo descartada uma resposta porque a empresa, embora autorizada a exercer a atividade de segurança patrimonial, possuía vigilantes com e função somente na sua própria instalação, sendo o restante dos trabalhadores voltados ao transporte de valores. 


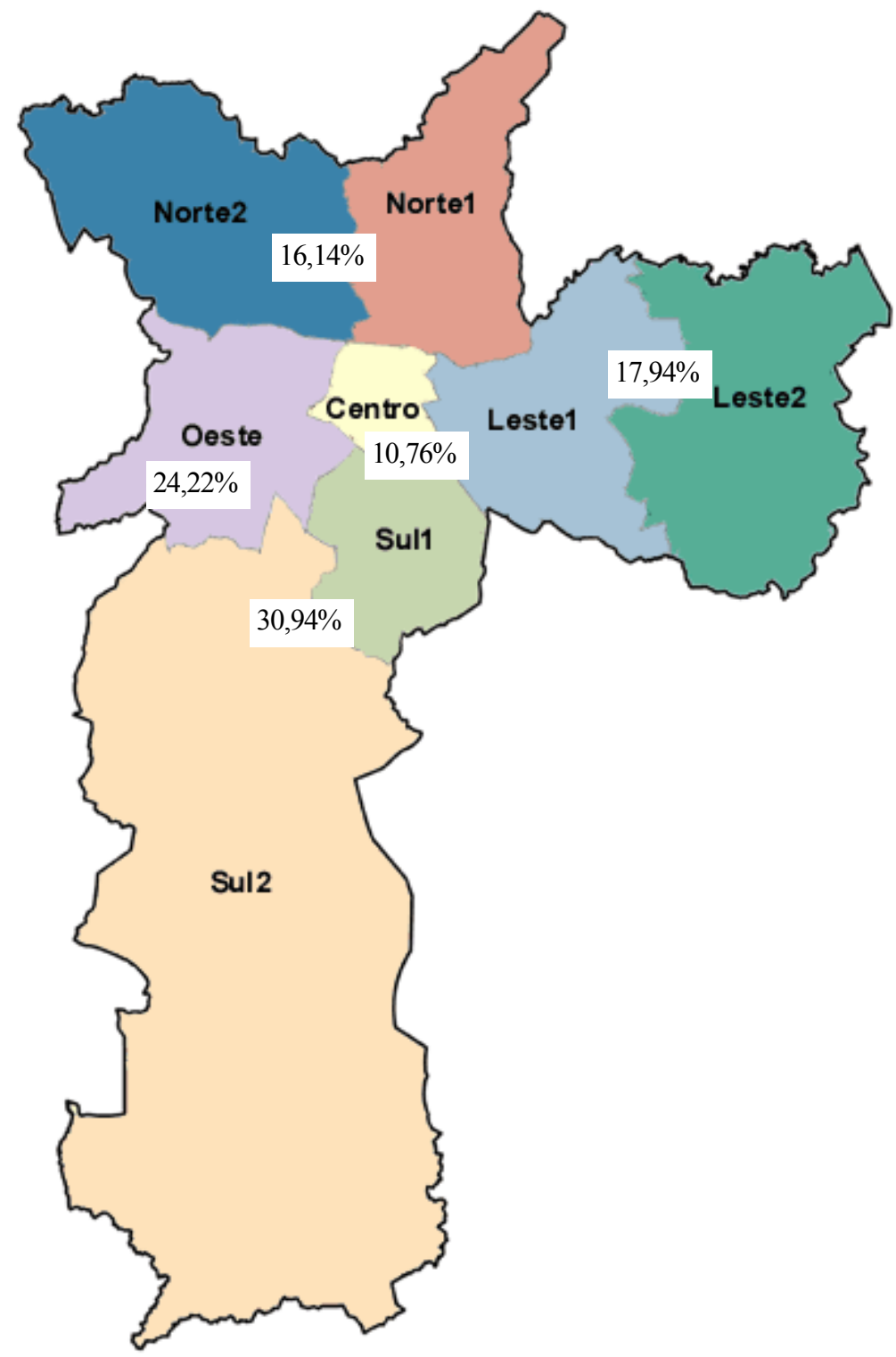

Figura 14 - Distribuição das empresas de segurança patrimonial na cidade de São Paulo

\subsection{Análise de Correspondência}

De acordo com Greenacre (1984) e Hair et al. (1995), esta técnica aplica-se com sucesso para o entendimento das relações entre as variáveis através de mapas, ou seja, com enfoque mais geométrico do que estatístico. 
Hair et al. (1995) acrescentam que a análise de correspondência destina-se à análise de dados com respostas categóricas, ou seja, que não são medidas em termos quantitativos, que sejam agrupados conforme sua alta correlação. A partir desse agrupamento pode-se reduzir no número de variáveis do modelo.

As variáveis propostas para este estudo possuem as características relacionadas a essa técnica. Adicionalmente, como o questionário foi formulado de forma a agregar mais de duas categorias em cada variável, procede-se de forma indicada por Crivisqui (1993), utilizando a Análise Fatorial de Correspondência Múltipla (AFCM).

Para estruturar a análise de correspondência torna-se necessário definir três componentes: indivíduos, variáveis e suas modalidades. De acordo com Escofier \& Pagès (1992), esses elementos podem ser representados através da Tabela de Burt, conforme apresentada no Quadro 2, através do número de indivíduos para cada variável e modalidade. Essa tabela caracteriza-se por incluir, em sua diagonal, a freqüência de cada modalidade para $J$ variáveis e por ser simétrica. Apenas as variáveis principais (ativas) são utilizadas na análise. Algumas variáveis coletadas foram excluídas dos cálculos e não influenciam nos resultados. Conforme Benzécri (1992), essas variáveis complementares podem ser representadas graficamente e auxiliarem na interpretação dos resultados. 


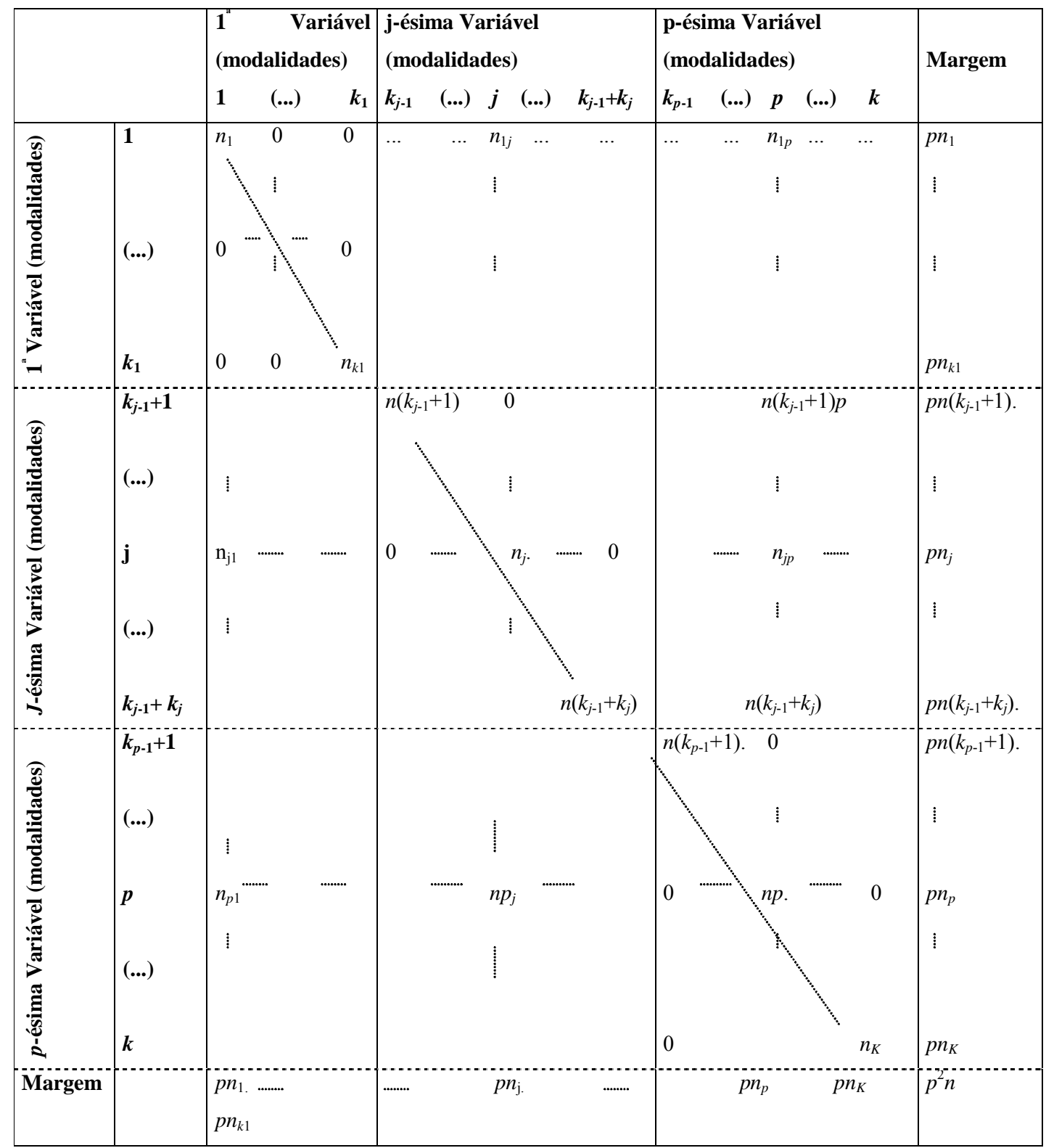

Quadro 2 - Representação da análise de correspondência múltipla através da Tabela de Burt

Fonte: Crivisqui (1993, p.230)

No presente estudo, considera-se um contexto analítico em que se tem $I$ indivíduos relacionados a cada uma das empresas amostradas; as $J$ variáveis qualitativas 
dizem respeito às questões descritas no Anexo $\mathrm{B}$; as $K$ modalidades estão associadas às respostas de cada pergunta.

Nesta tabela, $n_{j k}$ é o número de indivíduos que possuem a modalidade $j$ da $p$ ésima variável e a modalidade $k$ da $p$-ésima variável; $n_{k}$ é o $k$-ésimo elemento da margem da tabela, que corresponde ao número de indivíduos que possuem a modalidade $k$ de cada variável; $p^{2} n$ é a soma de todas as células da tabela, ou seja, corresponde ao total de indivíduos observados. Na presente pesquisa $j$ e $k$ representam possíveis respostas para as perguntas realizadas.

A representação espacial dessas informações é realizada através de coordenadas em linha e em coluna, conforme Crivisqui \& Batista (1998, p.27 e 37), utilizando a distância euclidiana de qui-quadrado, denominada Bénzecri, para ponderar a localização dos pontos. Esses pontos são conhecidos como perfis em linha e em coluna. De acordo com Crivisqui (1993), a partir desses perfis os dados qualitativos são transformados em fatores, quantitativos, que são, por sua vez, representados nos eixos fatoriais por suas coordenadas. O plano fatorial é composto por dois eixos, que representariam fatores determinantes de padrões de respostas entre as empresas de segurança privada. Além da determinação do comportamento geral das empresas em respostas individuais, esta abordagem pode auxiliar na identificação de perfis das empresas ligados com as variações de respostas. As fórmulas empregadas nos cálculos de distâncias estão especificadas nas eq. (7) e (8).

$$
d_{\left(i, i^{\prime}\right)}=\sqrt{\sum_{j=1}^{J} \frac{1}{f_{. j}}\left(\frac{f_{i j}}{f_{i .}}-\frac{f_{i^{\prime} j}}{f_{i^{\prime} .}}\right)^{2}} \forall i, i^{\prime} \in I
$$

onde:

$d_{\left(i, i^{\prime}\right)}$ : distância euclidiana entre dois elementos linha da tabela, ou seja, perfis em linha; $f_{i j}$ : freqüência relativa ao número total de observações do $i$-ésimo indivíduo (que apresenta a modalidade $j$ da $p$-ésima variável). 


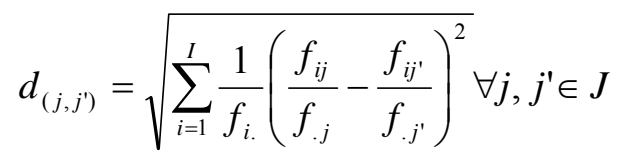

onde:

$d_{\left(j, j^{\prime}\right)}$ : distância euclidiana entre dois elementos coluna da tabela, ou seja, perfis em coluna;

A dispersão dos pontos em relação a um ponto de referência $(m)$, ou seja, a inércia, é outra medida que também auxilia na comparação dos pontos-perfis. Essa comparação permite expressar a correlação entre modalidades. Sua fórmula é apresentada na eq. (9).

$$
I_{m}=\sum_{i=1}^{I} p_{i} d_{(i, m)}^{2} \quad \forall i \in I
$$

onde:

$I_{m}:$ inércia da nuvem de pontos em relação ao ponto $m, I=\{1,2, \ldots, i\}$;

$p_{i}$ : peso (ou massa) associado a cada ponto $i$;

$d_{(i, m)}$ : distância entre cada ponto $i$ a $m$.

Há outros elementos que ajudam a interpretar as informações contidas nos planos fatoriais, conforme mostra o Quadro 3. 


\begin{tabular}{|l|l|l|}
\hline \multicolumn{1}{|c|}{ Medida } & \multicolumn{1}{|c|}{ Descrição } & \multicolumn{1}{c|}{ Fórmula } \\
\hline Autovalor & $\begin{array}{l}\text { indica o grau de relacionamento entre as } \\
\text { variáveis de cada eixo } \alpha, \text { a partir de suas } \\
\text { coordenadas fatoriais, } F_{\alpha}(i), \text { e auxilia na } \\
\text { definição do número de planos fatoriais } \\
\text { utilizados na análise }\end{array}$ & $\lambda_{\alpha}=s_{\alpha}^{2}=\sum_{i=1}^{I} p_{i}\left[F_{\alpha}(i)\right]^{2}$ \\
\hline $\begin{array}{l}\text { Contribuição } \\
\text { relativa dos } \\
\text { pontos-perfis }\end{array}$ & $\begin{array}{l}\text { identifica qual é a contribuição de cada } \\
\text { ponto perfil à formação do eixo } \alpha\end{array}$ & $C T R_{\alpha}(i)=\frac{p_{i}\left[F_{\alpha}(i)\right]^{2}}{\lambda_{\alpha}}$ \\
\hline $\begin{array}{l}\text { Contribuição } \\
\text { relativa dos } \\
\text { fatores }\end{array}$ & $\begin{array}{l}\text { mede a qualidade da representação da } \\
\text { distância do ponto-perfil } i \text { à origem do } \\
\text { eixo } \alpha, d(i, 0), \text { ou seja, quanto maior for } \\
\text { seu valor, maior será a associação do } \\
\text { ponto perfil } i \text { ao eixo fatorial } \alpha\end{array}$ & $\operatorname{COR} R_{\alpha}(i)=\frac{\left[F_{\alpha}(i)\right]^{2}}{d^{2}(i, 0)}$ \\
\hline
\end{tabular}

Quadro 3 - Descrição de medidas de interpretação dos planos fatoriais

Fonte: adaptado de Crivisqui (1993)

Há vários trabalhos que aplicaram a análise de correspondência fatorial para realizar agrupamento de empresas, como por exemplo, Anefalos (1999), Nogueira (2003) e Sherafat (2002), permitindo identificar padrões comuns entre diversas empresas participantes de um mercado. Neste estudo optou-se por conjugar esse método com a análise de conglomerados, para que se obtivesse classificação mais criteriosa das empresas de segurança privada.

\subsection{Análise de Conglomerados}

A análise considera a medida adequada para distinguir grupos e o algoritmo computacional para obter a melhor escolha. Além de ser empregada na análise de correspondência, a distância euclidiana também pode ser utilizada como medida para agrupar indivíduos, neste caso, empresas segundo características comportamentais comuns. Por conterem variâncias e covariâncias da amostra em sua fórmula, de acordo com Dillon \& Goldstein (1984), essas medidas de similaridade são indicadas para auxiliar nessa análise multivariada de conglomerados. 
O algoritmo pode ser hierárquico e não-hierárquico ${ }^{3}$. No primeiro caso, a separação dos grupos é realizada sem um conhecimento prévio quanto ao número de divisões. No segundo, torna-se necessário definir uma divisão inicial antes da formação dos grupos. Crivisqui (1998) ressalta que há possibilidade de se iniciar a análise com a classificação hierárquica, incorporando as informações da análise de correspondência, para obter o número de grupos mais adequado, e, posteriormente, empregar a nãohierárquica para compor cada um deles. $\mathrm{O}$ agrupamento de empresas no presente estudo serve na identificação dos perfis dos empresários, com possíveis diferenças entre si.

É, possível, portanto, conciliar esses dois métodos multivariados - análise de correspondência e de conglomerados-, para obter o perfil da segurança privada na cidade de São Paulo, a partir do agrupamento das informações contidas no questionário. Mesmo que o número de observações seja relativamente pequeno, estes métodos podem auxiliar na identificação de padrões comuns de comportamento das empresas em função das modalidades de respostas a perguntas particulares.

A seguir serão apresentados e discutidos os resultados iniciais obtidos a partir da pesquisa de campo, juntamente com a análise de dados secundários.

\footnotetext{
${ }^{3}$ Informações mais detalhadas poderão ser obtidas em Sharma (1996).
} 


\section{RESULTADOS DA PESQUISA EMPÍRICA SOBRE A ATIVIDADE DE SEGURANÇA PATRIMONIAL PRIVADA}

Neste capítulo são analisados os resultados da aplicação do questionário, apresentado no Anexo B, em empresas de vigilância patrimonial, interpretando as respostas com o marco teórico da Nova Economia Institucional. Busca-se esclarecer como diferentes estruturas de governança, influenciadas pelo ambiente institucional do setor, interferem sobre incentivos e mecanismos de controle do comportamento oportunista e sobre o fluxo de informações no sistema de prestação de serviços. Embora transações via mercado viabilizem alocações eficientes de recursos no atendimento de demandas por insumos padronizados em sistemas de segurança, como equipamentos e instalações, no caso dos recursos humanos a adequação da qualidade prometida ao demandante não é imediata pela assimetria de informações, situação em que órgãos de regulação, além de buscarem a defesa de interesses públicos de justiça e igualdade de proteção, devem interferir para estimular a concorrência e preservar a qualidade dos serviços prestados.

A discussão que prossegue reflete a necessidade de analisar transações de contratação de vigilantes intermediadas ou não por empresas de segurança privada e o papel da regulação do Estado na atividade.

\subsection{Estruturas de governança na prestação de serviços de vigilância patrimonial privada}

A capacidade para promover a qualidade e reduzir preços dos serviços de vigilância patrimonial é diferenciada entre estruturas de governança de transações. Atualmente, existem transações realizadas diretamente entre tomadores de serviços e 
vigilantes e transações intermediadas por empresas especializadas. A outra distinção refere-se à adequação dos agentes as normas da prestação dos serviços. Com relação ao Departamento de Polícia Federal (DPF), órgão de regulação da atividade, existe um conjunto de empresas e vigilantes não autorizados e que não cumprem regras específicas da atividade, o que estimula a análise da subdivisão entre serviços legal e ilegalmente constituídos.

\subsection{O mercado de prestação de serviços de vigilância irregular}

A pesquisa de campo buscou, fundamentalmente, identificar o comportamento das empresas de vigilância regulares em termos de incentivos e controles que promovem a qualidade dos serviços prestados. Contudo, entre os entrevistados a preocupação com a atividade clandestina é freqüentemente destacada, pois a competitividade por elas conseguida está diretamente relacionada com o descumprimento de normas de funcionamento da atividade. Esta seção apresenta uma formulação das estruturas de governança atuando no ramo clandestino da atividade de vigilância, seguindo opiniões emitidas pelos entrevistados em empresas regulares. Embora o grupo amostrado crie um viés na pesquisa, pela consistência de algumas opiniões preferiu-se apresentar esta formulação.

Os entrevistados reclamam do descumprimento de normas como uma maneira de reduzir custos, como os custos de treinamento de trabalhadores, pagamento de pisos salariais estabelecidos em acordos coletivos e recolhimento das obrigações trabalhistas e tributárias. Especialmente nas pequenas empresas os entrevistados sentem-se atingidos pela má conduta de outros participantes do mercado, pois por seu pequeno tamanho paira a suspeita de que o comprometimento com o respeito aos direitos dos trabalhadores e dos clientes pode ser menor, ao contrário das grandes empresas, tornando-os menos atrativos para melhores clientes e trabalhadores.

Os entrevistados queixaram-se de outra prática no setor, o desvio de função. Alguns afirmam que a contratação de porteiros para exercer funções de vigilantes, membros de categorias profissionais distintas, torna-se cada vez mais comum. Isto seria um reflexo do fato da atividade de vigilância configurar uma despesa não relacionada 
com a atividade fim dos tomadores de serviços, sendo que em períodos de queda nas margens de lucro é uma das primeiras a ser atingida por cortes nos custos. Inclusive alguns entrevistados que prestam serviços de conservação e portaria, contudo, afirmaram que o perfil e o preparo do profissional de vigilância é melhor que o de profissionais em atividades correlatas. Três entrevistados enfatizaram que problemas comportamentais, instabilidade emocional e profissional, e dificuldades de relacionamento tendem a ser mais graves e freqüentes com profissionais especializados nas atividades de portaria e conservação que profissionais de vigilância patrimonial.

A influência da legislação é crucial para diferenciar trabalhadores dos segmentos clandestinos e regulares da atividade. A legislação estabelece que os profisssionais de segurança não podem ter antecedentes criminais e devem possuir formação específica, participando de reciclagens a cada dois anos. Nos cursos de formação os vigilantes recebem instruções gerais sobre um conjunto de atividades ligadas a suas funções, tais como defesa pessoal, primeiros socorros, noções de tiro e armamento, prevenção e combate a incêndios, relações humanas, técnica operacional e segurança física de instalações.

Além da preparação para formar competências desejáveis para a segurança patrimonial, os vigilantes são avaliados psicologicamente e possuem remunerações superiores às remunerações de trabalhadores em atividades correlatas, o que, segundo os entrevistados, interfere diretamente no comportamento do indivíduo. Entrevistados afirmaram que a remuneração de vigilantes costuma ser o dobro ou mais, se contabilizadas horas-extras, da remuneração de porteiros. A concordância em pagar este diferencial reflete a aplicação de recursos para manter os profissionais comprometidos com os interesses de defesa dos patrimônios, o que é uma evidência de que a prática de pagar uma remuneração acima das alternativas como forma de incentivo aos trabalhadores, dentro da idéia do salário de eficiência, funciona neste mercado em particular.

A contratação direta de trabalhadores clandestinos coloca os tomadores diante de uma forte assimetria de informações no mercado de trabalho, como ilustra a Figura 15. $\mathrm{O}$ desrespeito às exigências mínimas de treinamento e requisitos individuais prejudica 
muito a percepção dos contratantes sobre a qualidade média dos indivíduos, tornando grave o problema de seleção adversa de trabalhadores. Os trabalhadores contratados, ao receberem baixas remunerações, são pouco incentivados a não se comportarem de maneira oportunista. Ademais, o monitoramento de seu comportamento não inclui a supervisão especializada de profissionais de empresas de segurança, ficando ao encargo apenas dos contratantes, o que aumenta o espaço para problemas de risco moral. Transações são orientadas no sentido da busca por menores preços, sacrificando a qualidade dos serviços. Ações oportunistas dos vigilantes podem implicar em prejuízos ao patrimônio defendido e na responsabilização dos contratantes em problemas criminais, cíveis, administrativos e fiscais. A responsabilidade criminal pode ocorrer pelo exercício de atividade para a qual está impedido por decisão administrativa e até mesmo o porte ilegal de armas.

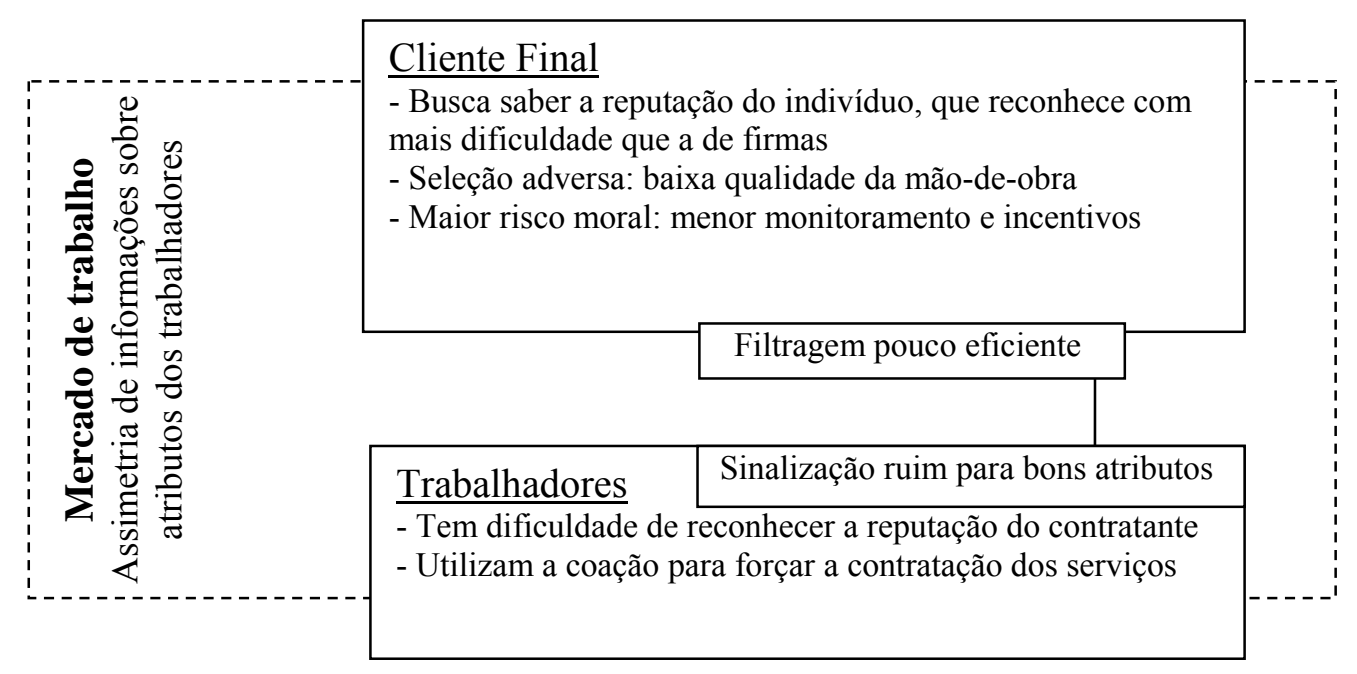

Figura 15 - Representação esquemática da transação no mercado clandestino de prestação de serviços

Embora seja desejável melhorar processos de seleção de trabalhadores, procedimentos costumam ser custosos e imprecisos na identificação dos atributos. Mesmo em empresas especializadas em vigilância, os testes psicológicos, por exemplo, foram apontados como um recurso limitado de seleção. Os testes seriam eficientes 
apenas para indicar se o desvio de personalidade individual seria grande ou não. A imprecisão dos testes associada com o pequeno número de indivíduos contratados tornaria menos relevantes os ganhos com a filtragem em termos de elevação da aptidão média do conjunto de trabalhadores, não justificando maiores investimentos na constituição de um corpo especializado para a seleção de vigilantes.

Os sinais de qualidade oferecidos pelos trabalhadores clandestinos podem ser ruins. Se o trabalhador envolveu-se em atividades de baixa remuneração, os incentivos a permanecer em um emprego seriam baixos e seu histórico registrado na carteira profissional pode desfavorecê-lo. A pouca escolaridade indicaria a baixa qualidade da mão-de-obra, pressionando para baixo as remunerações.

O exercício de funções policiais pode servir como um sinal de cumprimento de requisitos mínimos para o exercício da atividade além de uma forma de conseguir favores do corpo policial. Por isso, o segundo emprego de policiais, conhecido como "bico", pode ser difundido pela vantagem do policial no mercado de trabalho informal. A péssima conduta de alguns indivíduos contribui para deteriorar a imagem da força policial, ou seja, cria "efeito carona".

A representação na Figura 16 refere-se à estrutura do mercado clandestino de vigilância patrimonial privada, em que empresas fazem a intermediação de trabalhadores e tomadores de serviços. É uma estrutura de governança híbrida, em que acordos informais de prestação de serviços controlam a relação. Segundo os entrevistados, as empresas formalmente constituídas atuam clandestinamente para tirarem proveito de menor carga tributária, como empresas de portaria que usam o sistema SIMPLES, e não pagamento das remunerações com base nos pisos salariais da categoria, além de não cumprirem exigências de pagamentos de taxas na emissão de alvarás de funcionamento e nas vistorias. 


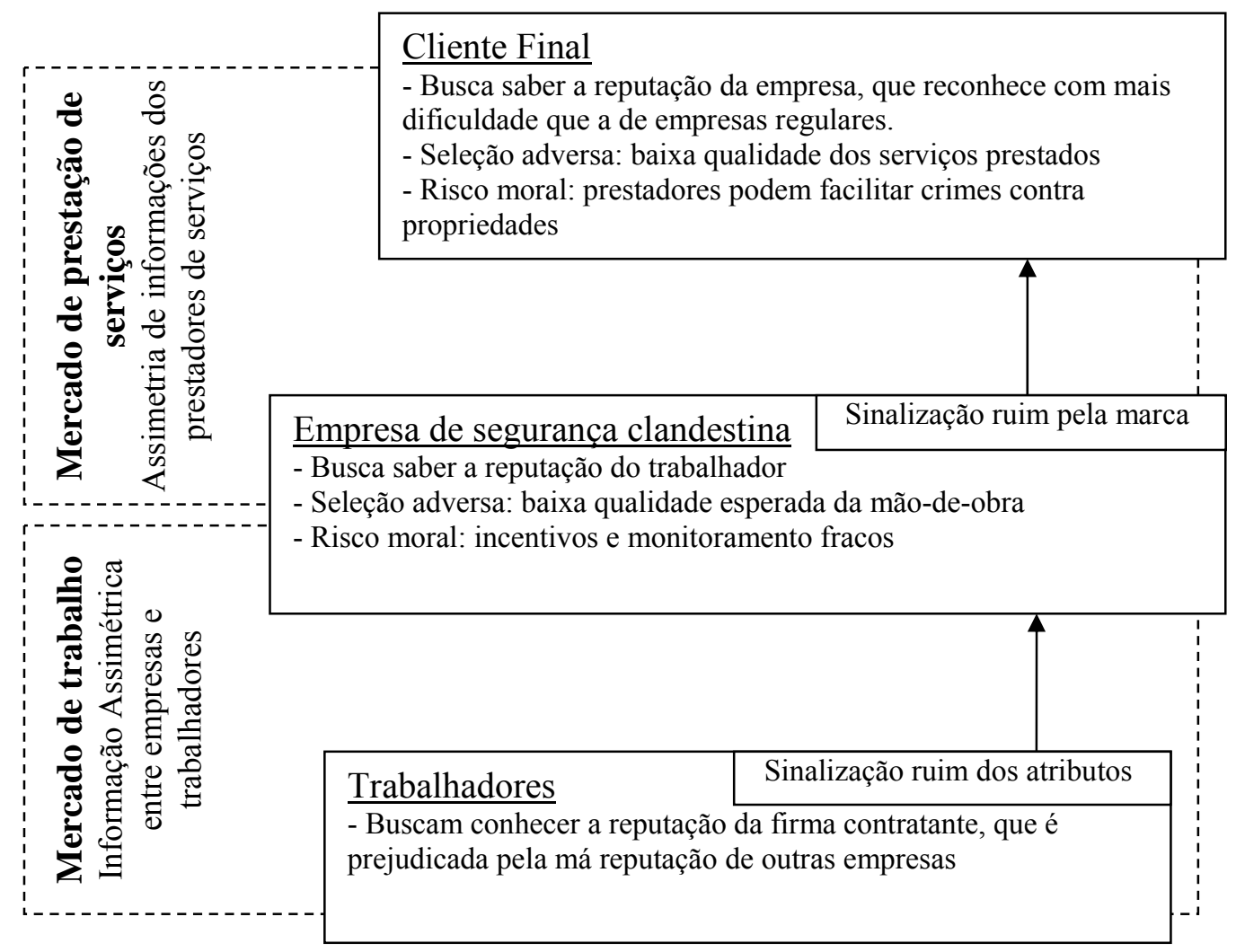

Figura 16 - Representação dos serviços de vigilância constituídos por empresas clandestinas

Esta forma de prestação de serviços pode implicar na responsabilização criminal da empresa pelo exercício de atividade para a qual está impedida por decisão administrativa, responsabilidade ainda maior no caso do emprego de trabalhadores armados. O mecanismo de construção da reputação não é viabilizado nesta situação, pois a visibilidade da empresa clandestina pode colocá-la diante de punições previstas em lei. A reputação de prestadores regulares é prejudicada pela atividade de empresas clandestinas, sendo a sinalização de marca pouco eficiente, levando a concorrência das empresas ser baseada na queda de preços.

A dificuldade de expansão de suas atividades, associada com a baixa remuneração, limita a capacidade das firmas em atrair bons candidatos aos postos de 
trabalho, criando um problema típico de seleção adversa. O emprego de trabalhadores não treinados, falhas no monitoramento e a ausência de incentivos ao comportamento honesto implicam problemas de risco moral, em que ações dos agentes clandestinos de segurança podem facilitar os crimes às propriedades e pessoas.

As empresas clandestinas utilizam equipamentos e fardamento que as confundem com os prestadores de serviços regulares. É comum no patrulhamento de ruas o uso de etiquetagem em carros, de uniformes, de giroflex e de rádios, por exemplo. Os entrevistados ressaltaram que esta prática depõe contra a atividade regular, pois abusos envolvendo empresas clandestinas levam o público, desavisado sobre a diferença de atuação, a generalizar a má reputação para os prestadores de serviços regulares.

\subsection{Atividade regular de segurança privada}

A regulamentação dos serviços estabelece padrões mínimos de treinamento e de comportamento, mas nos espaços privados também as determinações específicas de proprietários interferem nas normas e procedimentos de segurança, para a adequação do trabalhador às características do sistema de segurança privada. Esta adequação assegura a eficiência do sistema em termos de bloqueio de acesso, monitoramento e controle do público, para fins de prevenção de delitos e defesa de patrimônios e pessoas.

Em função dos requisitos de atributos individuais, grande parte do trabalho das empresas está em estabelecer processos adequados de seleção de trabalhadores. Para lidar com o problema de oportunismo pós-contratual, os esquemas de incentivos e monitoramento também devem ser analisados na cadeia de serviços. Entre a contratação direta e a contratação de terceiros, importa também distinguir a necessidade de adaptação requerida das estruturas de governança distintas.

\subsubsection{Contratação de vigilantes para uso próprio (serviços orgânicos)}

A contratação direta de trabalhadores é permitida pelo Departamento de Polícia Federal, sendo necessário, no entanto, obter autorização para a constituição de serviços orgânicos. Como discutido no capítulo 2, empresas orgânicas representam, atualmente, uma pequena parcela do emprego regular de vigilantes, constituídas principalmente 
quando o contratante final tem demandas específicas que justificam a administração direta dos trabalhadores. Os entrevistados afirmam que empresas devem assumir custos administrativos e envolverem-se em atividades não relacionadas com sua atividade fim, implicando que investimentos sejam feitos nos processo de seleção e recrutamento, de treinamento e supervisão. Na Figura 17 é representado parte do sistema de prestação de serviços em que uma estrutura de governança hierárquica incorpora as atividades típicas de uma empresa de vigilância.

A presença de assimetria de informações leva ao emprego de processos de filtragem, identificação de sinais de qualidade emitidos pelos trabalhadores, e a utilização de incentivos e monitoramento para assegurar o comportamento honesto. $\mathrm{O}$ treinamento e a reciclagem nesta circunstância têm que ser atendido por um treinamento bastante específico, como afirmam os entrevistados, para justificar a incorporação da atividade aos processos da empresa. Esta especificidade mais elevada justifica a forma hierárquica como estrutura de governança adequada para a condução das transações.

O monitoramento direto dos trabalhadores, sem interferência de um prestador de serviços, confere à empresa a possibilidade de ajustar seu comportamento com maior liberdade, indicando que a capacidade adaptativa da estrutura de governança é maior. No caso da forma híbrida, discutida a seguir, é costumeiro acontecer um conflito entre os interesses de prestadores de serviços e clientes com relação às atividades de vigilantes, diminuindo o poder de adaptação cooperativa às novas circunstâncias.

Entrevistados afirmaram também que as empresas orgânicas, ou seja, que realizam a contratação direta, são em número reduzido devido à cobrança de taxas para vistoria e expedição de alvarás pelo Departamento de Polícia Federal, caros para empresas não especializadas cobrirem. 


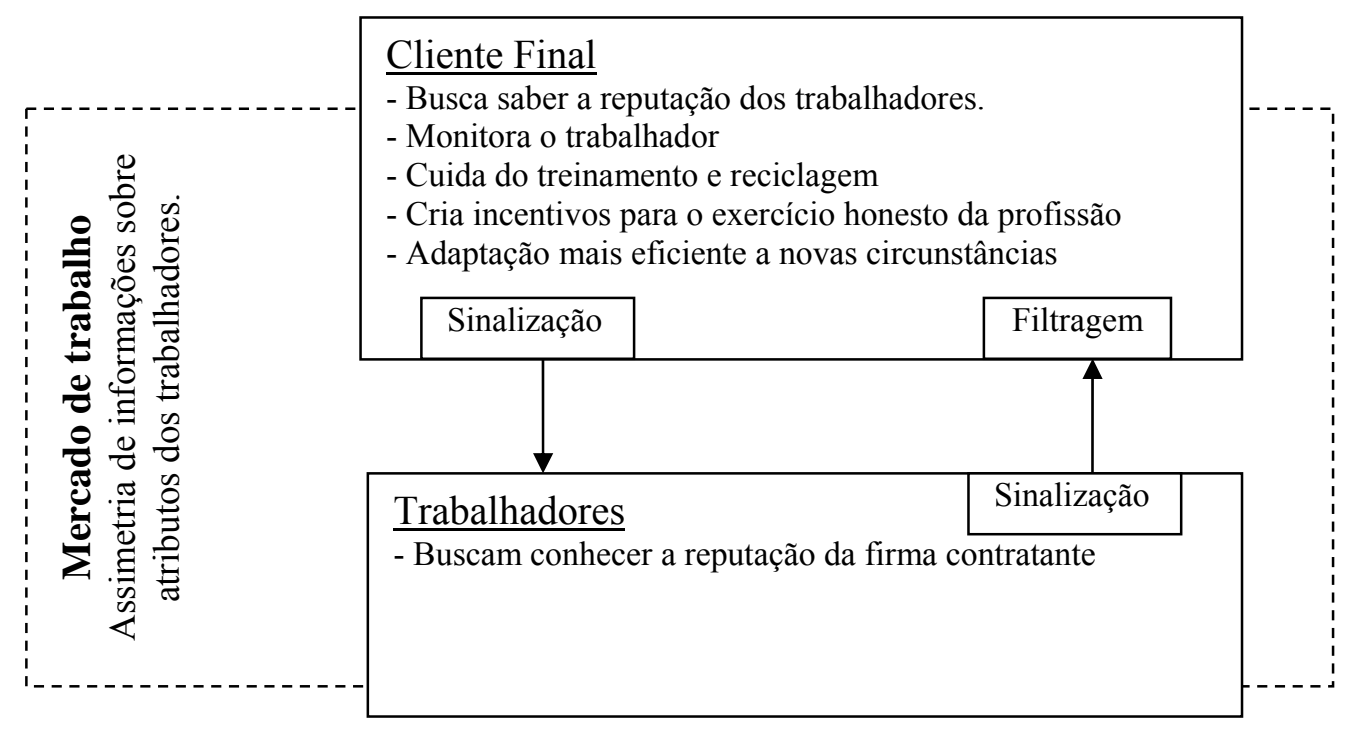

Figura 17 - Representação dos serviços de segurança privada contratados para uso próprio

Outro problema com este tipo de contratação seria a dificuldade para se manter a regularidade na vigilância em casos de faltas, folgas e substituição dos ocupantes dos postos de trabalho. Empresas especializadas mantém trabalhadores na reserva para este tipo de cobertura, e poderiam facilmente recompor a mão-de-obra.

A substituição de trabalhadores em uma empresa orgânica implicaria demissões e custos de rescisão de contratos de trabalho, principalmente pela multa do fundo de garantia e o aviso prévio, além dos custos de procura e seleção de outro vigilante. Substituições intermediadas por empresas de segurança não necessariamente implicariam nesses custos. Se transações fossem conduzidas com esta estrutura de governança, os custos de procura por postos de trabalho e de participação de processos de admissão seriam maiores para os trabalhadores.

\subsubsection{Contratação de empresas de segurança privada}

Seguindo os argumentos de Vining e Globerman (1999), na ótica da análise de custos de transação, para a terceirização ser um caminho recomendável devem-se ter 
como atributos a combinação de baixa especificidade de ativos com baixa complexidade dos produtos, serviços ou atividades envolvidas. No caso dos serviços de vigilância patrimonial, o treinamento pode tornar mais específico o capital humano contratado, mas boa parte deste treinamento inclui conhecimentos gerais. A especificidade no caso da terceirização não deve ser tão alta como no caso anterior. A clareza das atividades, que chegam a ser padronizadas em manuais de normas e procedimentos, parece preencher o segundo requisito para a terceirização bem sucedida. A menor especificidade implicaria uma dependência mais fraca entre as partes envolvidas nas transações, com rompimentos de relações provocando pequenos danos aos envolvidos.

Dentre os custos de transação, os custos de negociação de termos contratuais são relativamente baixos, existindo contratos bem estabelecidos e padronizados entre empresas de segurança e clientes, como entrevistados revelaram. O custo de procura de trabalhadores tende a ser menor para trabalhadores nesta atividade, sendo determinante para a capacidade de atrair bons empregados o fato das firmas cumprirem obrigações trabalhistas. Nas entrevistas afirmou-se que os candidatos procuram informações sobre o cumprimento de prazos previstos para pagamentos, sobre o recolhimento de encargos, sobre a concessão de benefícios e sobre as possibilidades trabalho remunerado com horas extras. Como as firmas intermedeiam o vigilante e um grande número de clientes, os custos de procura por empregos e de participação dos processos de seleção são menores para trabalhadores. Onze das dezessete empresas visitadas formam bancos de dados para convocação posterior de vigilantes, classificando os candidatos por região em que moram, para minimizar custos com transporte.

As transações entre os agentes no mercado de serviços são freqüentes e podem ser rompidas unilateralmente, sendo grande o número de participantes. Esta alta freqüência de transações torna importante a reputação dos prestadores de serviços na continuidade das transações e expansão do número de clientes, principalmente para consolidar marcas e aumentar a credibilidade dos anúncios da empresa. 
Marca consolidada no mercado.

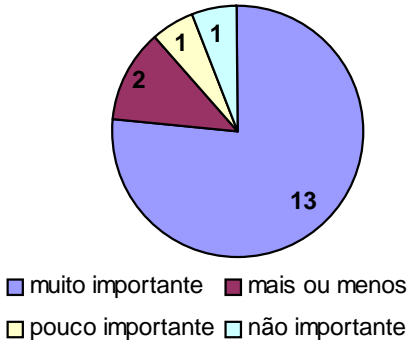

Indicação de outros clientes.

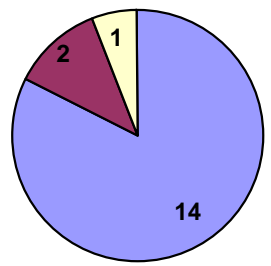

$\square$ muito importante $\square$ mais ou menos $\square$ não importante
Preço do serviço of erecido melhor do que os concorrentes.

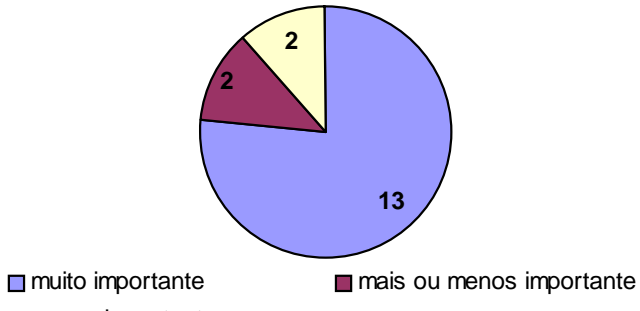

$\square$ pouco importante

Funcionários uniformizados.

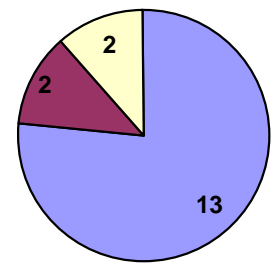

$\square$ muito importante $\square$ mais ou menos $\square$ pouco importante

Figura 18 - Número de respostas por categoria, indicando os fatores que estimulam clientes a contratarem os serviços da empresa

A maioria dos entrevistados apontou a marca consolidada como um fator importante para estimular clientes a contratarem seus serviços. O uso de uniformes serve como um meio importante de divulgar a marca da empresa, pois acompanha uma demonstração, através da postura do vigilante, da qualidade do serviço prestado. A indicação de outros clientes também é uma forma comum de ampliar o número de tomadores de serviços, fortalecendo a idéia de que o sucesso da empresa depende diretamente de sua reputação. O preço dos serviços oferecidos foi considerado por alguns prestadores como pouco ou mais ou menos importante para promover negócios. Alguns afirmam que praticam preços superiores aos observados no mercado, com contratos diferenciados de prestação de serviços, ou seja, oferecendo uma contrapartida de maior qualidade na supervisão, no treinamento e no perfil do vigilante, por exemplo. 
A Figura 19 mostra que contratação de serviços através de contratos diferenciados é bastante incomum

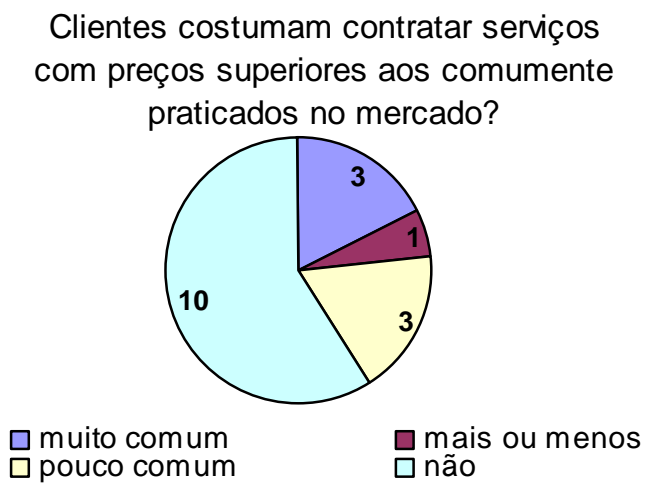

Figura 19 - Número de respostas por categoria, indicando o quão costumeira é a contratação de serviços com preços superiores aos praticados no mercado

Todos consideraram que o cumprimento de manual de normas e procedimentos, a aparência do vigilante, a supervisão contínua e o uso de uniformes como muito importantes para a melhoria da reputação da empresa. A presença do vigilante uniformizado, muito embora este não possua poderes de policiamento superiores ao de um cidadão comum, leva à inibição das ameaças às propriedades e pessoas, contribuindo para os sistemas de segurança privados. A baixa substituição dos vigilantes nos postos de trabalho foi apontada por 12 empresas como muito importante para melhorar sua reputação, como mostra a Figura 20. Isto revela que experiência com clientes e boa qualidade dos serviços são fundamentais na construção da reputação da empresa. 


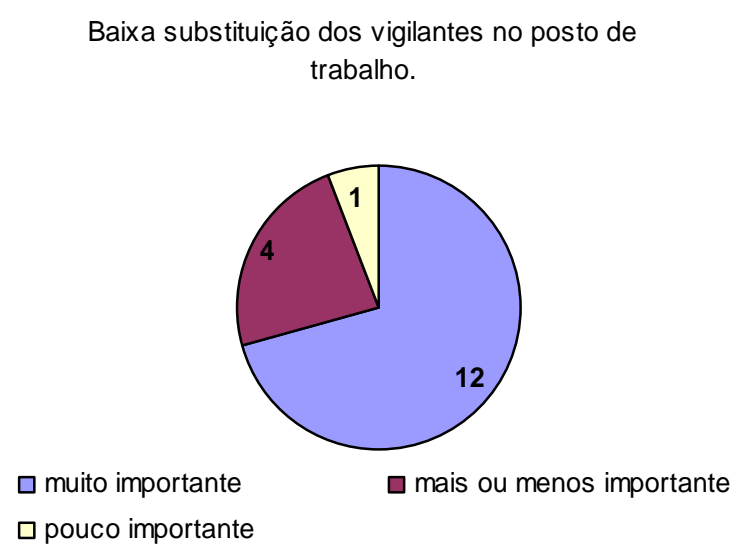

Figura 20 - Número de respostas por categoria, indicando o efeito da baixa substituição de trabalhadores na melhoria da reputação da empresa

As firmas podem sinalizar a qualidade, ou seja, transmitirem informações para clientes com base em sua marca ou na obtenção de um certificado privado, como atualmente o faz o Sindicado das Empresas de Segurança Privada, Segurança Eletrônica, Serviços de Escolta e Cursos de Formação do Estado de São Paulo (SESVESP). Entre os entrevistados foram encontrados prestadores que afirmam ser o Certificado de Regularidade em Segurança (CRS) do SESVESP um meio eficaz de diferenciação, enquanto outros dois empresários, não certificados, declararam-se insatisfeitos com seu lançamento por sentirem-se discriminados.

Para garantir o cumprimento de compromissos contratuais quanto à qualidade, os prestadores de serviços estão preocupados em atender seus clientes com agilidade nos momentos de ocorrências de delitos, nas faltas não previstas de vigilantes, justificadas ou não, bem como na substituição de agentes quando solicitado. As empresas de segurança podem alterar a alocação de vigilantes com facilidade, o que garante a adequação do interesse dos trabalhadores aos interesses dos clientes. Quatorze dos dezessete entrevistados afirmaram que pedidos de substituição dos trabalhadores costumam implicar na alocação dos indivíduos em postos juntos a outros clientes, não sua demissão. 
Os entrevistados apontam também para a substituição programada de vigilantes como um recurso utilizado pelos clientes para evitar a criação de vínculos entre vigilantes e trabalhadores da empresa tomadora de serviços, que os tornariam coniventes com pequenas infrações ou má conduta de trabalhadores. Como mostra a Figura 21, em comércios e shoppings centers haveria uma freqüência mais elevada de pedidos de substituição de vigilantes, em função do contato com um maior número de pessoas, o que aumentaria a chance de pequenos conflitos e incidentes. Este mesmo motivo foi alegado para condomínios e instituições financeiras. Este tipo de pedido de alteração do ocupante de um posto de trabalho revela o quão importante pode o papel da empresa de recolocação do vigilante, evitando custos de procura de novo emprego para o trabalhador e custos de demissão e admissão para o tomador de serviços, se a contratação fosse direta. Serviços de vigilância são bens de crença, não sendo possível mensurar alguns atributos mesmo depois do consumo realizado, sendo o motivo da empresa manter funcionários substituídos, avaliando sua conduta em outros postos. Pela dificuldade de mensuração de atributos, a reputação da empresa traz a informação sobre a qualidade dos serviços, e para evitar danos à reputação os prestadores de serviços podem demitir maus funcionários mesmo com custos nos processos rescisórios. 

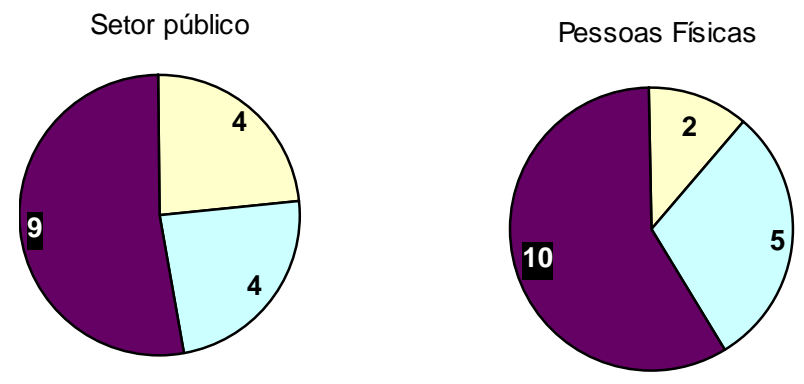

Comércio e Shopping Center's
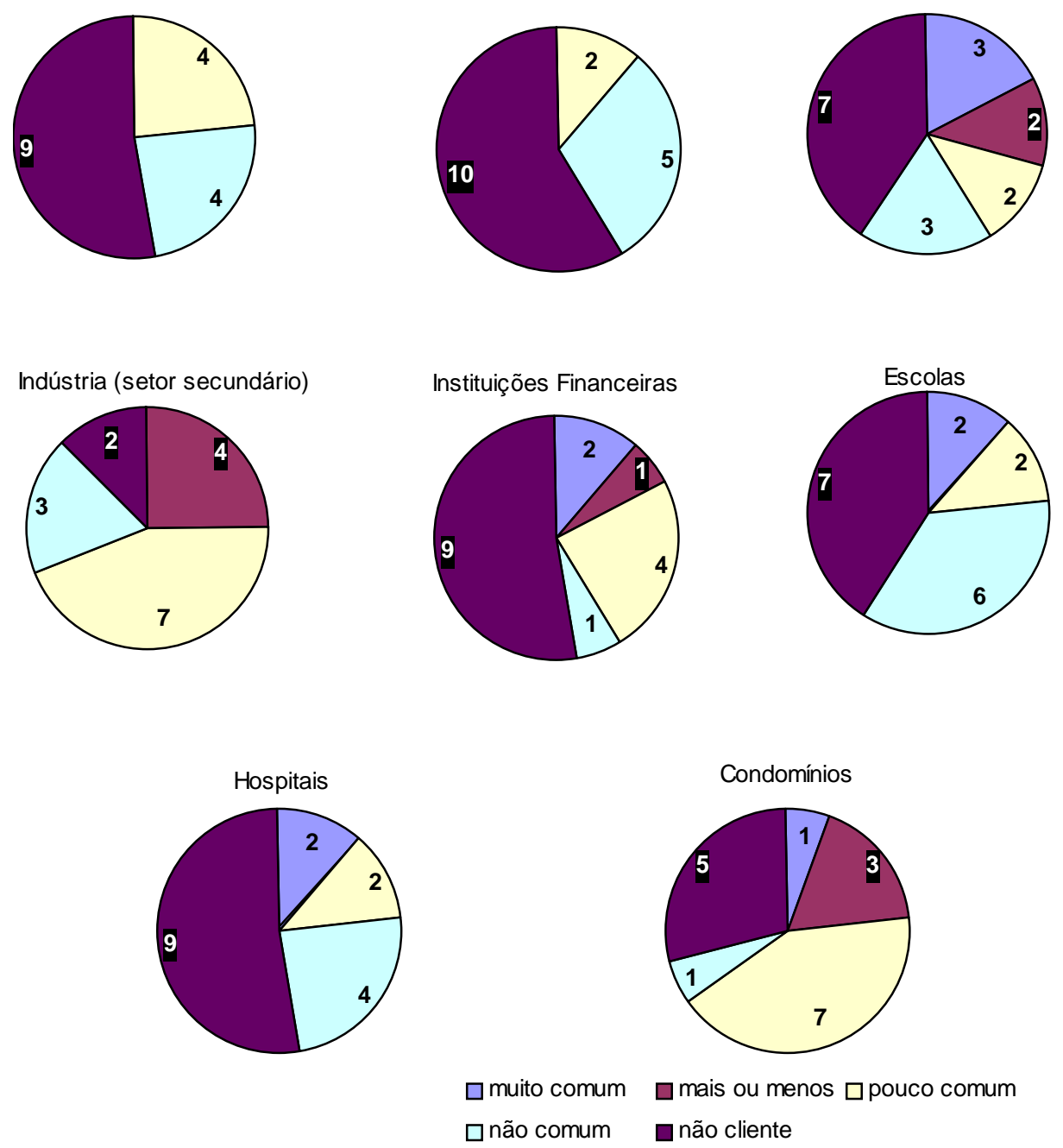

Figura 21 - Número de respostas por categoria, dos tipos de cliente que comumente pedem a substituição de trabalhadores nos postos de vigilância

A Figura 19 mostra as interações entre agentes na prestação de serviços regulares. 


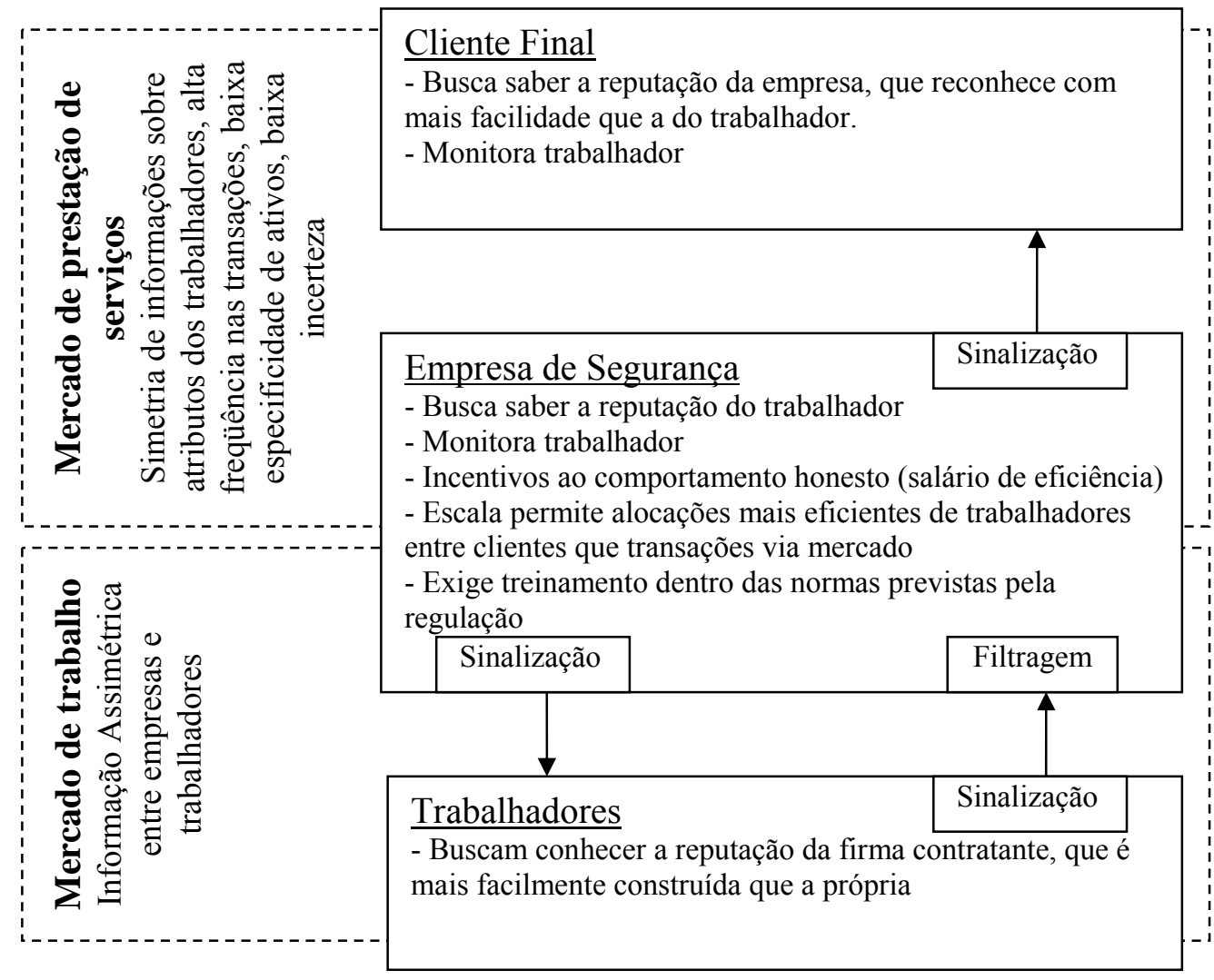

Figura 22 - Representação da prestação de serviços por empresas regulares

O número grande de postos de trabalho confere às empresas uma flexibilidade que permite regularidade na prestação dos serviços, assegurando aos trabalhadores uma ocupação desde que a prestadora de serviços reconheça e confie em seus atributos. As empresas de segurança patrimonial costumam preservar os melhores funcionários se os postos de trabalho junto aos clientes forem perdidos, criando com esses vínculos de longo prazo. A filtragem e a sinalização de qualidade são cruciais na contratação de trabalhadores, para minimizar danos da assimetria de informações.

Dentre os entrevistados, a escolaridade do vigilante é apontada como fator importante pela maioria dos prestadores de serviços. A escolaridade tanto interfere no capital humano quanto serve como um de um sinal de qualidade na admissão de vigilantes. Cursos de formação e reciclagem também são apontados como importantes 
para a promoção da qualidade dos serviços, contribuindo substancialmente para a formação dos trabalhadores.

A informação sobre a estabilidade dos funcionários nos postos de trabalho mantidos pela empresa é importante para tornar a firma atrativa para trabalhadores, reduzindo o problema de seleção adversa na contratação. Os entrevistados enfatizaram também a importância do monitoramento e incentivos na prestação de serviços de qualidade.

O problema da assimetria de informações permanece no mercado de trabalho, mas o prestador de serviços terceirizados é mais eficiente em transmitir informações de qualidade e alocar recursos. A firma pode ampliar sua escala e reputar qualidade aos empregados, superar a relutância dos contratantes, investir em processos de seleção que auxiliem na identificação de atributos, conseguir ganhos de escala, criar incentivos via salário de eficiência, por exemplo.

\subsubsection{Monitoramento do trabalhador}

Outra característica importante na atuação das empresas de segurança privada seria o monitoramento dos trabalhadores em conjunto com o cliente. Treze dos entrevistados consideraram ser pouco ou não importante o impacto dos salários elevados em relação ao mercado sobre a necessidade de supervisão dos trabalhadores, como observado na Figura 23. Entretanto, entrevistados acreditam que os salários elevados em relação às alternativas que os trabalhadores possuiriam no mercado tornariam esses mais eficientes e reduziriam a rotatividade, corroborando as implicações da adoção de uma estratégia de salário de eficiência nas empresas. 


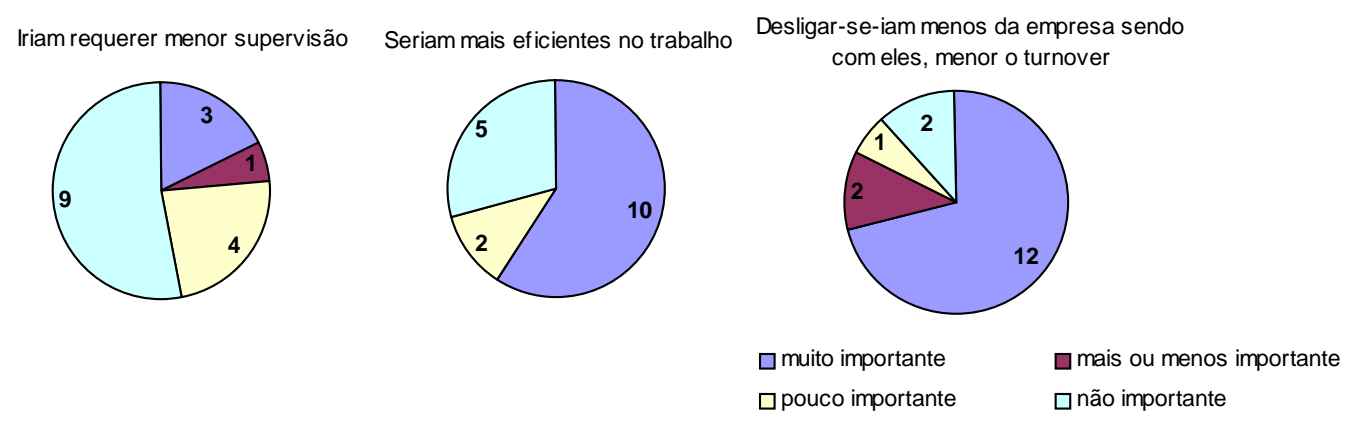

Figura 23 - Número de respostas por categoria, do impacto da remuneração sobre a supervisão, a eficiência e a rotatividade de trabalhadores

Tanto a empresa de segurança quanto o prestador de serviços são responsáveis pelo monitoramento do trabalhador na atividade formal. Os entrevistados afirmam que é comum ocorrer uma forte vinculação do trabalhador com o cliente, como pode ser visto na Figura 24. Uma das maiores queixas com relação a esta fixação do trabalhador no posto de trabalho refere-se ao efeito sobre sua disciplina. $O$ empregado passa a não seguir normas e procedimentos estabelecidos pela empresa prestadora de serviços, como o uso adequado do uniforme ou o tratamento impessoal no local de trabalho. Alegam que o vigilante passa a contar com o apoio do cliente e por este passa a ser protegido na quebra das normas e procedimentos. Segundo os entrevistados, em caso de ameaça de demissão do trabalhador, o cliente pode reagir, inclusive, com a substituição da empresa prestadora do serviço por outra que mantenha o vigilante no posto de trabalho.

Este efeito reflete um problema de menor capacidade de adaptação cooperativa na forma híbrida do arranjo institucional, que seria minimizado caso o contratante realizasse a integração vertical da atividade e monitorasse com exclusividade o comportamento do vigilante. Um dos entrevistados destaca a vinculação especialmente forte no setor público, onde o vigilante tende a ser protegido por funcionários preocupados com os problemas do trabalhador. 
É comum que a conduta do vigilante crie um forte vínculo entre este e o cliente, que fixa o indivíduo no posto de trabalho?

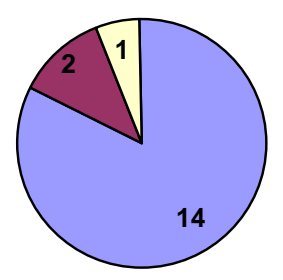

Esta fixação do empregado no posto pode ocasionar problema:

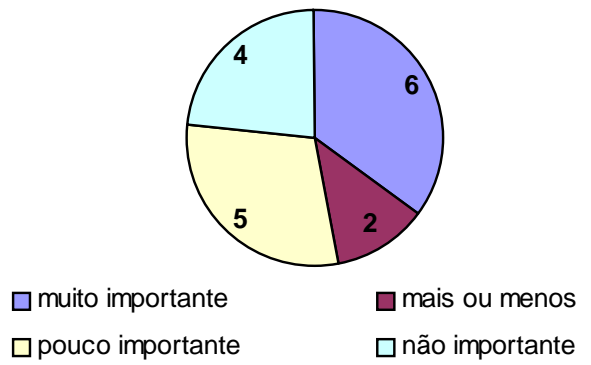

Figura 24 - Número de respostas por categoria, sobre a vinculação entre clientes e trabalhadores

\subsubsection{Remuneração de trabalhadores e eficiência}

As avaliações de supervisores e clientes não foram apontadas como importantes para alteração da remuneração dos trabalhadores, como pode ser visto na Figura 25. Avaliações influenciariam muito mais nas decisões de rompimento da relação trabalhista que na alteração de salários dos trabalhadores. Contudo, três entrevistados apontaram que os vigilantes costumam se beneficiar de favores dos clientes, o que aumenta a lealdade com os últimos.

Avaliação do supervisor

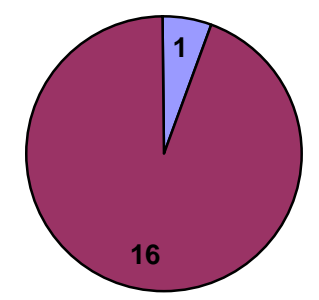

Avaliação do cliente

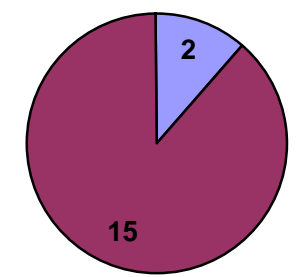

não importante

Figura 25 - Número de respostas por categoria, da influência das avaliações sobre a remuneração de trabalhadores 
Como estabelecido em acordo coletivo da categoria, os empregados nas mesmas funções possuem direito à isonomia nos rendimentos, podendo ser motivos de disputas judiciais os descumprimentos deste termo. Os entrevistados afirmam que os empregados comparam os comprovantes de rendimentos, queixando-se imediatamente de diferenças que são eliminadas para evitar a desmotivados nos grupos de trabalho. Manter a uniformidade nos pagamentos para indivíduos com as mesmas funções auxilia no incentivo ao trabalho de equipe, afirmam entrevistados. A diferenciação acontece através da promoção de trabalhadores a líderes de equipes, por exemplo, como uma pequena elevação da remuneração. Isto não causa problemas se forem utilizados critérios mais objetivos para a promoção, como a assiduidade do funcionário no emprego e ação correta em crimes.

A uniformidade no pagamento mantida pelos empresários, pela dificuldade de mensurar os resultados diferenciados do trabalho, e a remuneração maior relativamente à profissões correlatas, indica a prática do salário de eficiência como principal incentivo ao comportamento adequado do trabalhador. Durante as entrevistas foram apontadas razões que parecem sustentar a idéia de que salários são relativamente altos para promoção do comportamento honesto dos trabalhadores. Alguns afirmaram que o patamar de remuneração, que variou entre $\mathrm{R} \$ 681,65$ e $\mathrm{R} \$ 1.500,00$, incluindo horas extras, determina a vinculação do trabalhador com a empresa. Afirmaram também que muitos dos vigilantes originam-se de atividade na indústria que expulsaram mão-deobra, ingressando na profissão em busca de remunerações maiores que ocupações alternativas no setor de serviços.

Em escalas de trabalho de doze horas por trinta e seis de folga, a remuneração do vigilante fica bastante reduzida, e a insatisfação tende a forçar desligamentos. Para elevar a remuneração dos trabalhadores, horas extraordinárias são consideradas como muito importantes por quase todos entrevistados. As vantagens financeiras, que ao serem oferecidas por clientes permitem elevar a remuneração dos trabalhadores, o tempo de emprego e a assiduidade não foram apontados como fatores relevantes, como mostra a Figura 26. 
Cliente of erece vantagem financeira em relação

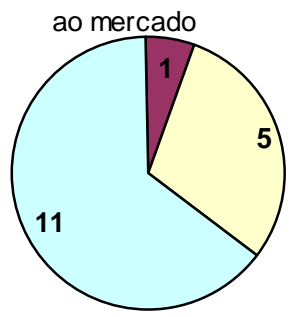

Premiação por assiduidade

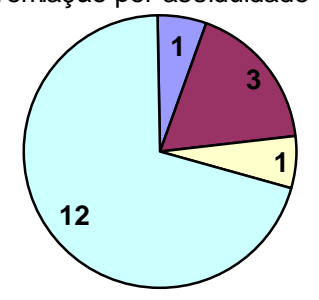

Tempo de emprego

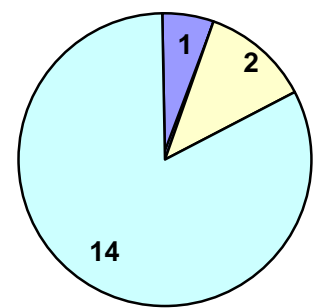

Horas extras

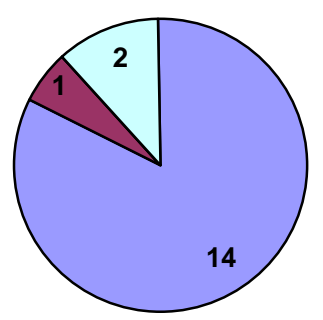

$\square$ muito importante $\square$ mais ou menos

$\square$ pouco importante $\square$ não importante

Figura 26 - Número de respostas por categoria, dos fatores que influenciam na diferenciação das remunerações de trabalhadores

Em dezesseis empresas a remuneração básica de trabalhadores é igual ao piso salarial da categoria, firmado em acordo coletivo de trabalho, mas este piso é maior que o de atividades correlatas de portaria, por exemplo. Menos da metade das firmas possui contratos de prestação de serviços que permitem pagamentos diferenciados aos trabalhadores, o que é previsto em acordos coletivos.

Indivíduos com melhor remuneração na empresa que no mercado de trabalho apresentam menor rotatividade que os demais. Os entrevistados apontaram que é comum o "desvio de função", ou seja, o emprego de trabalhadores de outras funções na vigilância. Contudo, os entrevistados alegaram que contratar indivíduos qualificados como vigilantes para funções com remuneração inferior, principalmente se já houverem trabalhado como vigilantes, tende a causar de grande insatisfação do trabalhador. 


\subsubsection{Promoção da qualidade dos serviços}

Escolaridade, supervisão constante, e remuneração igual à de outros indivíduos com a mesma função são importantes para promover a qualidade dos serviços, acreditam os entrevistados. Cursos de formação e reciclagem de vigilantes são ressaltados como importantes na promoção da qualidade da mão-de-obra, além do treinamento específico para o posto de trabalho, como mostra a Figura 28.

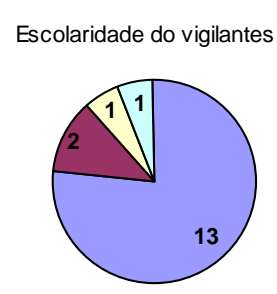

Curso de formação

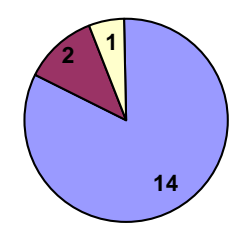

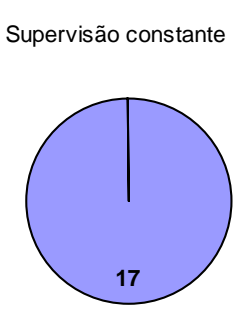

Treinamento específico para o posto de trabalho

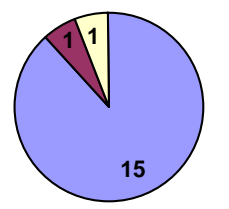

Reciclagem

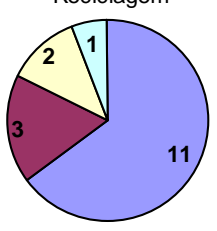

$\square$ mais ou menos importante

$\square$ não importante

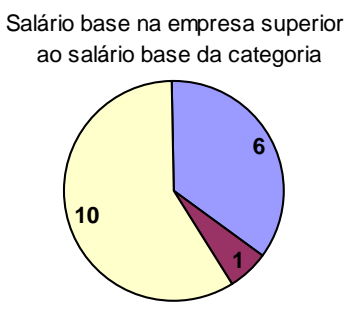

Manter a igualdade de remuneração com vigilantes na mesma funcão, para evitar conflitos

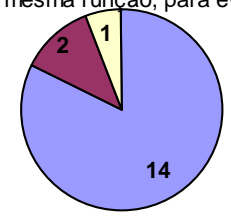

$\square$ muito importante $\square$ pouco importante

Figura 27 - Número de respostas por categoria, dos fatores que influenciam na promoção da qualidade dos serviços

Para reduzir a rotatividade dos trabalhadores, os entrevistados acreditam serem muito importantes o bom relacionamento entre cliente e vigilante, o pagamento de horas extras e as escalas de trabalho apropriadas à prática dessas horas, a concessão de benefícios, um grande número de clientes para assegurar uma colocação do trabalhador em algum posto, como mostra a Figura 28. Os planos de carreira praticamente não 
existem na atividade, sendo que as ascensões ocorrem geralmente para a função de líder de equipe ou para o transporte de valores, no caso de a empresa exercer também esta atividade. A assiduidade não costuma ser premiada, mas faltas e atrasos costumam ser punidos.

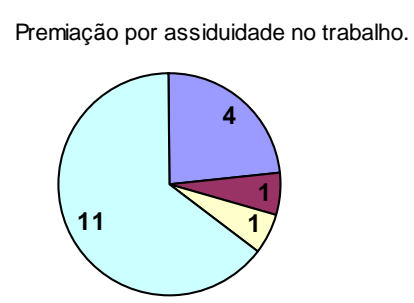

Escala de trabalho adequada ao interesse do vigilante

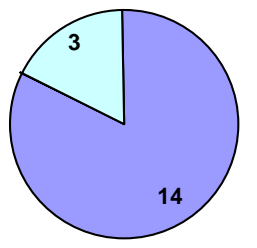

Bom relacionamento entre vigilante e cliente

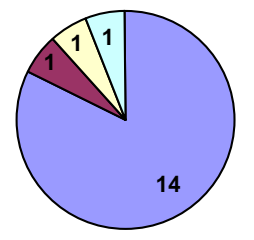

Grande número de clientes, assegurando ao empregado uma colocação em algum posto.

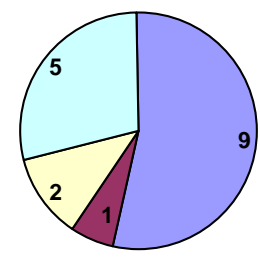

Plano de carreira, se existir, ou ascensão para outras funções.

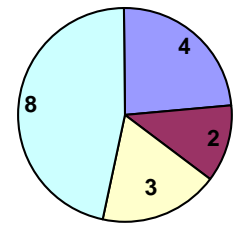

Benefícios extras, como cesta básica

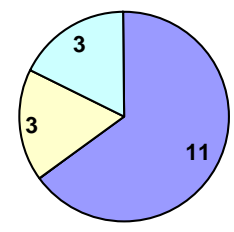

Turnos de trabalho adequados ao interesse do vigilante

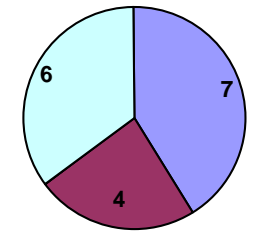

Pagamento de horas extras

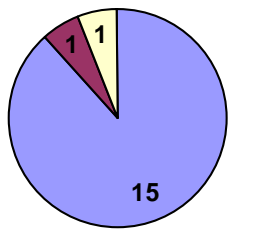

Melhores equipamentos, que reduzem os riscos do trabalho

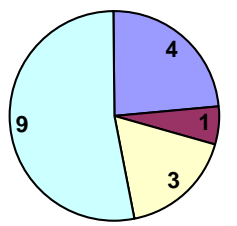

$\square$ muito importante $\square$ mais ou menos $\square$ pouco importante $\square$ não importante

Figura 28 - Número de respostas por categoria, dos fatores que influenciam na redução da rotatividade dos trabalhadores

Apontam também para a importância do respeito ao trabalhador como um meio de promoção da relação de trabalho, o que nem sempre acontece nas empresas, como afirmam alguns dos entrevistados. Alguns demonstraram esta forte preocupação porque os empregados da atividade seriam originados de postos de trabalho que deixaram de existir em atividades industriais, que o trabalhador considerava ser sua colocação profissional adequada. Muitos teriam ingressado na profissão de vigilante por esta the 
oferecer uma remuneração mais elevada que outras ocupações, mas manteriam seu interesse profissional ligado com a ocupação anterior.

A maioria dos entrevistados afirma que os vigilantes procuram postos de trabalho que, além de uma remuneração razoável e respeito aos direitos trabalhistas, os livrem do problema da rotatividade e do subemprego no mercado de trabalho. A boa reputação da empresa no mercado de prestação de serviços contribui também para transmitir confiança ao trabalhador de que seu emprego será mantido, com implicação imediata sobre o valor percebido para o fluxo de remunerações futuras. Como a reputação estende-se para todo o mercado, ela funciona diretamente para a atração de bons trabalhadores e minimiza o problema da seleção adversa. A Figura 26 ilustra os danos provocados pela rotatividade dos trabalhadores.

Insegurança por parte do cliente

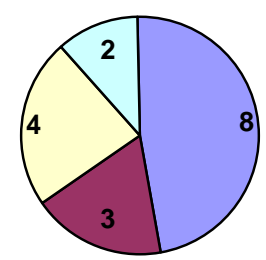

Custo de seleção de trabalhadores

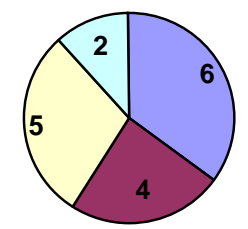

Custo de treinamento de mão-de-obra para reposição

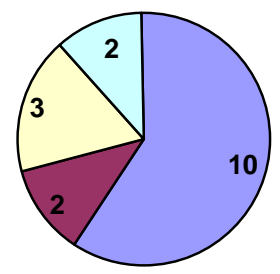

Custo do processo de rescisão de contrato

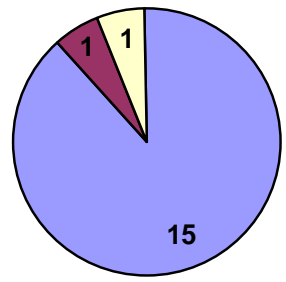

$\square$ muito importante

$\square$ pouco importante a mais ou menos importante

口não importante

Figura 29 - Número de respostas por categoria, dos danos provocados pela rotatividade de trabalhadores 


\subsubsection{Recrutamento e admissão}

A admissão de trabalhadores foi destacada entre os empresários como um processo crítico. Por ser uma profissão na qual a mão-de-obra do sexo masculino predomina, a filtragem de trabalhadores pode trazer um ganho de informação significativo em termos de eliminação de indivíduos com fortes desvios de comportamento. Os empresários mostraram-se preocupados em mapear cuidadosamente as características dos candidatos, com o emprego intenso de exames psicotécnicos e de questionários padronizados para as entrevistas com candidatos, envolvendo uma equipe especializada no recrutamento. A estabilidade profissional do trabalhador em uma empresa reconhecida no mercado costuma ser um importante diferenciador da mão-deobra, assim como a realização de exames psicológicos.

Embora os entrevistados considerem os testes psicológicos atualmente empregados como limitados na determinação para a aptidão do indivíduo para funções específicas, quase todos acreditam que os testes conseguem eliminar grande parte dos casos sérios de desvios de comportamento, como mostra a Figura 30. Referências de outros trabalhadores e empresas onde trabalhou são bastante consideradas no processo de admissão, existindo em geral uma pequena rede de relacionamentos que transmite informações entre empresários e revela a reputação dos trabalhadores.

A aparência do trabalhador também foi apontada como um critério importante na seleção, como mostra a Figura 30. A capacidade de comunicação, por sua vez, tem importância limitada porque em muitos postos de trabalho requerem indivíduos com características justamente contrárias a esta.

Uma prática em algumas empresas consiste na investigação social, em que visitas ocorrem no local de residência do trabalhador e perguntas sobre seu comportamento são dirigidas a familiares, amigos e vizinhos. Entre as empresas, o uso deste recurso pareceu ser limitado, muito embora seja considerado muito eficaz. Constatou-se que existem empresas especializadas na investigação do passado do trabalhador, que procuram informações sobre a conduta em locais de trabalhos anteriores e de moradia. A escolaridade superior ao ensino fundamental foi apontada como importante para a 

promoção da qualidade dos serviços, destacando a tendência de emprego de trabalhadores com escolaridade secundária.
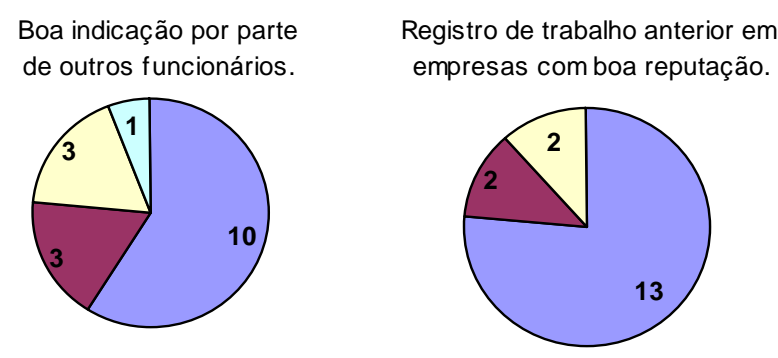

Escolaridade superior à do ensino
fundamental (superior à $8^{\mathrm{a}}$ série).

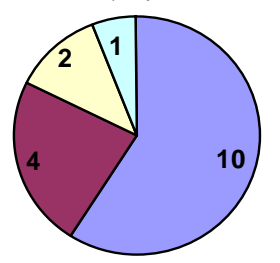

Informações provenientes de vizinhos, familiares ou de pessoais (investigação social).
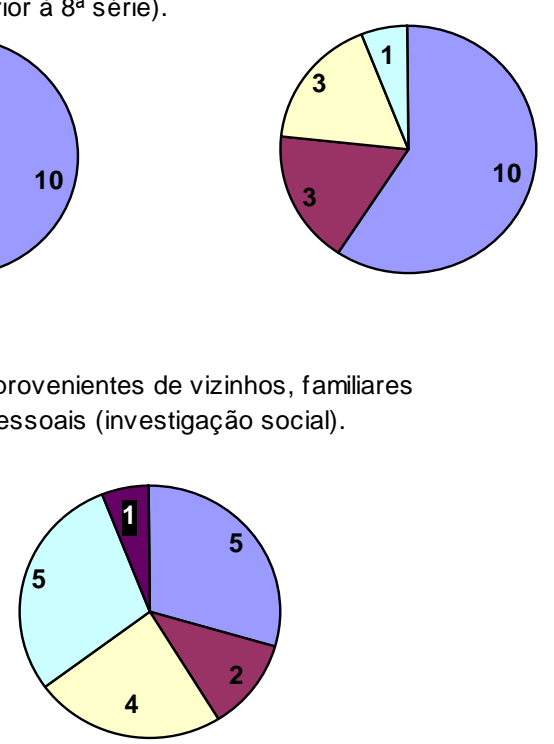

Aparência física

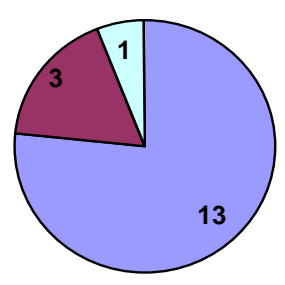

Bem avaliado psicologicamente.

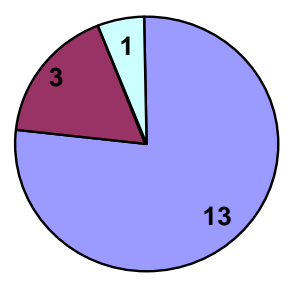

Informações provenientes de contato direto com empresas em que esteve empregado.

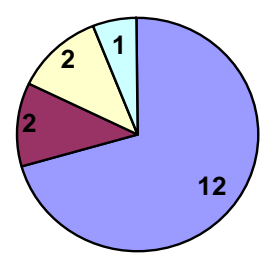

.

\section{$\square$ muito importante $\square$ mais ou menos $\square$ pouco importante} $\square$ não importante $\square$ não utiliza 
Figura 31, sendo a contratação errada causa de problemas graves, como o abalo da relação com os clientes e custos com o processo rescisório.
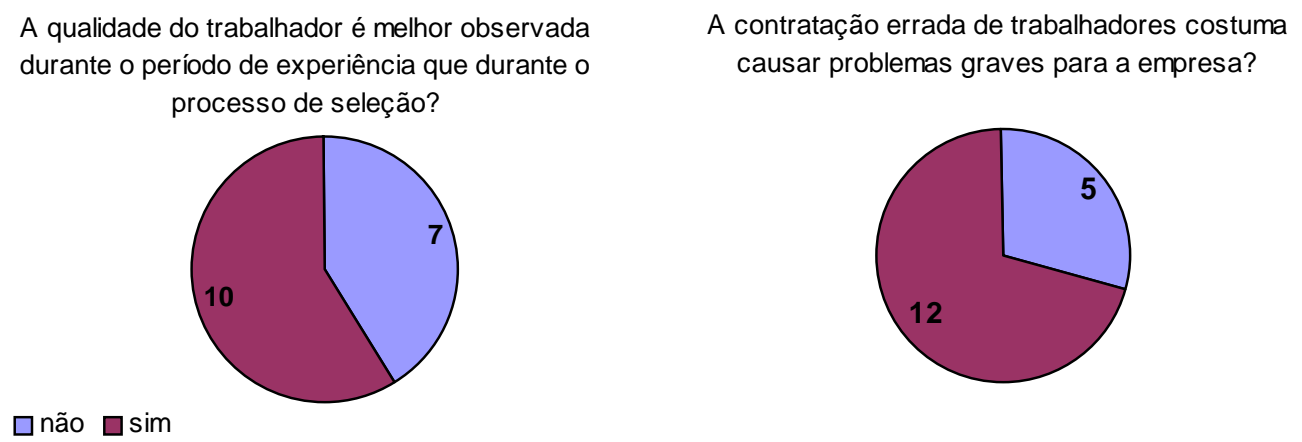

Figura 31 - Número de respostas por categoria, sobre a importância da filtragem de trabalhadores em processo seletivos

A maioria das empresas adota uma política de não recontratar trabalhadores, o que funciona como um incentivo à lealdade. $\mathrm{O}$ exame da Figura 32 mostra que uma das empresas terceiriza o processo de seleção de trabalhadores, prática incomum porque esta é uma das principais funções assumidas pelas empresas de segurança privada. A contratação via candidatos que buscam a empresa por iniciativa própria, a consulta a funcionários e a divulgação ampla de abertura de processos seletivos é bastante comum. A consulta a cursos de formação não é comum, mas algumas empresas o fazem quando se tratam de bons cursos de formação. 


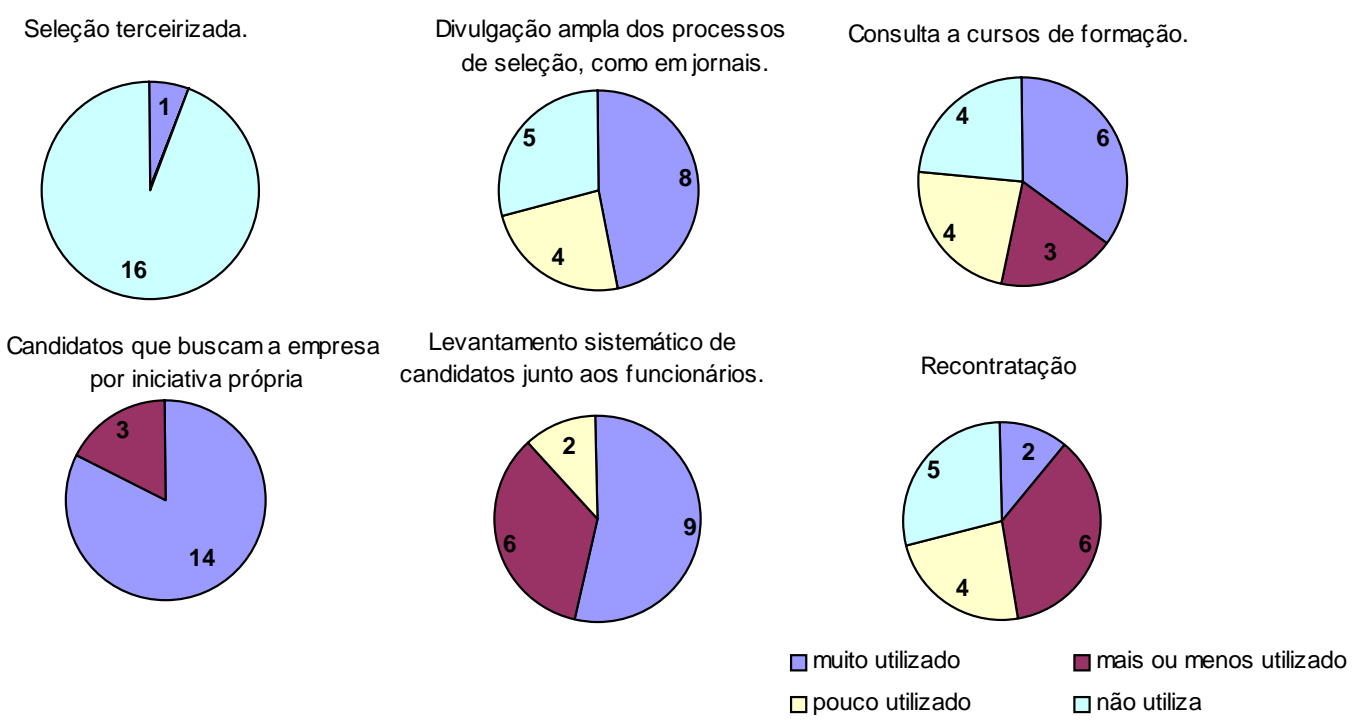

Figura 32 - Número de respostas por categoria, sobre a freqüência de utilização de meios de contratação

\subsubsection{Desligamento de trabalhadores}

A causa mais freqüente para o desligamento é o fim do contrato de prestação de serviços, como pode ser visto na Figura 33, situação na qual as empresas vêem forçadas a demitir seus funcionários por não haverem postos suficientes para alocar todos os trabalhadores. Erros graves, como dormir em trabalho, reprovação do trabalhador por clientes e supervisores seriam a segunda causa de desligamentos, indicando falhas no comportamento dos vigilantes. Incentivos institucionais, como a busca por indenizações na justiça do trabalho e o interesse em usufruir do seguro desemprego, que faria o empregado provocar sua demissão, não são apontados como muito relevantes na maioria das empresas. A busca por outras carreiras e remunerações melhores, não adaptação a turnos de trabalho e exigências de esforço físico dos postos não aparecem como causas importantes para desligamentos. A remuneração foi considerada como razoável em algumas entrevistas, afirmando o entrevistado que o histórico de empregos dos vigilantes mostra que esses, muitas vezes, trabalham em ocupações com remunerações menores que a da atividade. 
Vigilante dormiu em local de trabalho ou cometeu erro grave.

Vigilante não foi aprovado

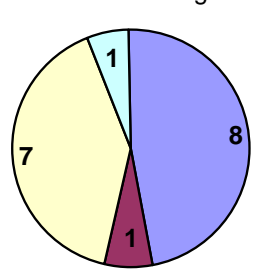

Vigilante não se adaptou às exigências de esforço físico do posto

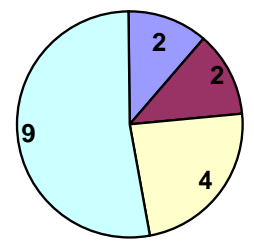

Vigilante não foi aprovado pela supervisão da empresa.
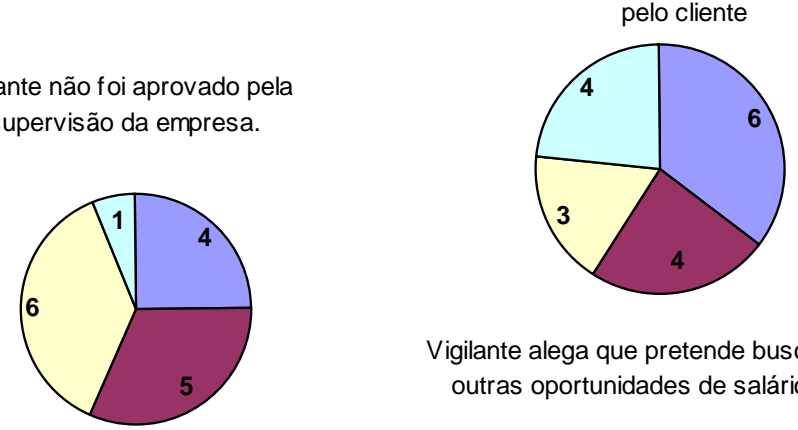

Vigilante alega que pretende buscar outras oportunidades de salário.

Vigilante não se adaptou aos turnos de trabalho

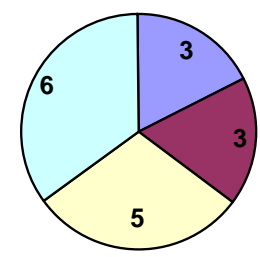

Contrato de prestação de serviços foi terminado
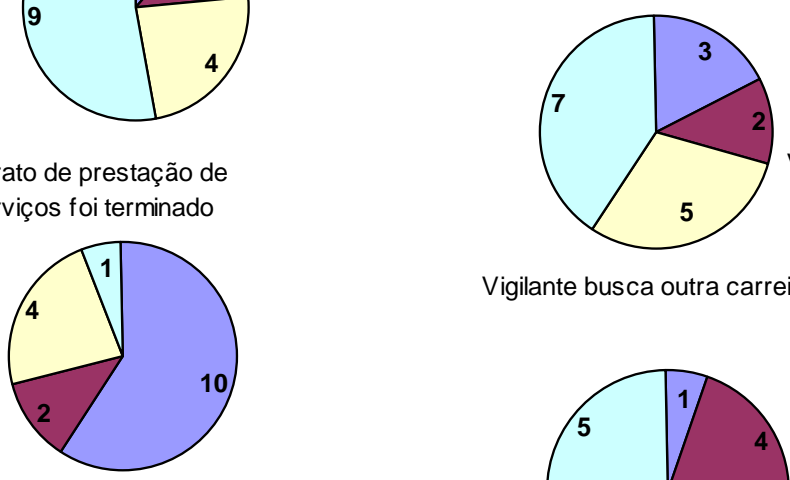
o fim do contrato de prestação dos serviços.

Vigilante busca outra carreira

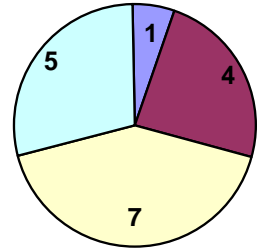

Vigilante sente-se estimulado por oportunidades

Vigilante sente-se estimulado pelo seguro desemprego.

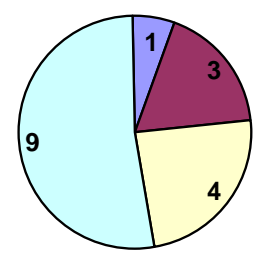

muito importante $\square$ pouco importante

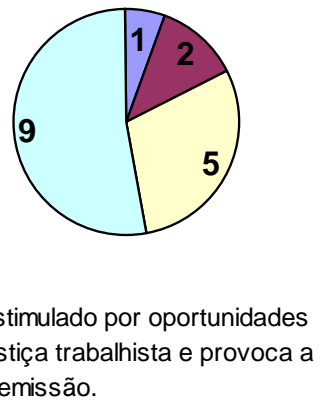
demissão.

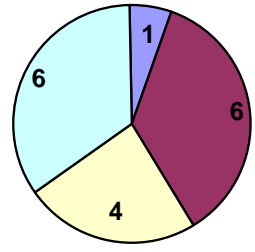

mais ou menos importante $\square$ não importante

Figura 33 - Número de respostas por categoria, sobre causas de desligamentos de trabalhadores 


\subsubsection{Análise de correspondência e de cluster aplicadas à análise de resultados}

A análise de correspondência foi adotada para reduzir o número de variáveis qualitativas (total de 79) e transformá-las em fatores (variáveis quantitativas) para proceder ao agrupamento das empresas que possuíssem características homogêneas por meio da análise de cluster. A Tabela 5 apresenta a decomposição da inércia, sendo que sua porcentagem decai com o segundo eixo fatorial.

Tabela 5. Decomposição da Inércia e teste Qui-quadrado

\begin{tabular}{|c|c|c|c|c|c|c|c|c|c|}
\hline Valor & Inércia & Qui & & Porcentagem & & & & & \\
\hline Singular & Principal & Quadrado & Porcentagem & Cumulativa & 3 & 6 & 9 & 12 & 15 \\
\hline 0,51998 & 0,27038 & 4939,6 & 12,53 & 12,53 & \multicolumn{5}{|c|}{ 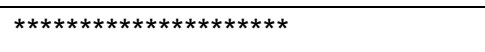 } \\
\hline 0,46192 & 0,21337 & 3898 & 9,88 & 22,41 & \multicolumn{5}{|c|}{ 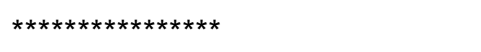 } \\
\hline 0,44234 & 0,19567 & 3574,6 & 9,06 & 31,48 & \multicolumn{5}{|c|}{ 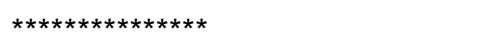 } \\
\hline 0,43271 & 0,18724 & 3420,6 & 8,67 & 40,15 & \multicolumn{5}{|c|}{ 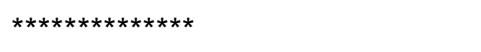 } \\
\hline 0,40506 & 0,16407 & 2997,4 & 7,6 & 47,75 & \multicolumn{5}{|c|}{ 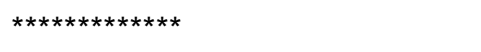 } \\
\hline 0,38454 & 0,14787 & 2701,5 & 6,85 & 54,6 & \multicolumn{5}{|c|}{ 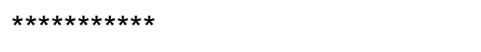 } \\
\hline 0,3813 & 0,14539 & 2656 & 6,74 & 61,34 & \multicolumn{5}{|c|}{ 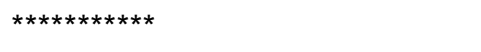 } \\
\hline 0,36254 & 0,13144 & 2401,2 & 6,09 & 67,43 & \multicolumn{5}{|c|}{ 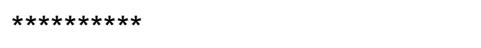 } \\
\hline 0,35491 & 0,12596 & 2301,1 & 5,84 & 73,26 & \multicolumn{5}{|c|}{ 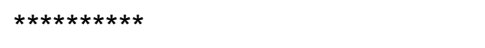 } \\
\hline 0,32967 & 0,10868 & 1985,5 & 5,04 & 78,3 & \multicolumn{5}{|c|}{ 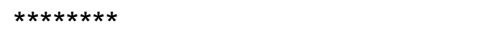 } \\
\hline 0,3163 & 0,10004 & 1827,7 & 4,63 & 82,93 & \multicolumn{5}{|c|}{ 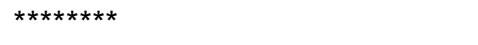 } \\
\hline 0,31146 & 0,09701 & 1772,3 & 4,49 & 87,43 & \multicolumn{5}{|c|}{ 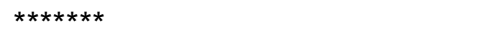 } \\
\hline 0,28379 & 0,08054 & 1471,4 & 3,73 & 91,16 & \multicolumn{5}{|c|}{ 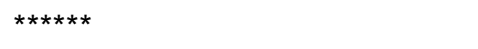 } \\
\hline 0,26176 & 0,06852 & 1251,8 & 3,17 & 94,33 & \multicolumn{5}{|c|}{ 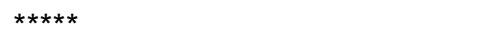 } \\
\hline 0,25637 & 0,06573 & 1200,8 & 3,05 & 97,38 & \multicolumn{5}{|c|}{$\star \star \star \star \star *$} \\
\hline 0,23798 & 0,05663 & 1034,6 & 2,62 & 100 & \multicolumn{5}{|l|}{$\star \star \star \star *$} \\
\hline Total & 2,15854 & 39434,1 & 100 & & & & & & \\
\hline \multicolumn{3}{|c|}{ Graus de liberdade $=$} & 66564 & & & & & & \\
\hline
\end{tabular}

A queda de porcentagem mais acentuada nas duas primeiras linhas apresentada na Tabela 5 indica que dois eixos fatoriais são suficientes para explicar o comportamento observado das variáveis, o que resultou na criação de um plano fatorial, mostrado na Figura 34. 


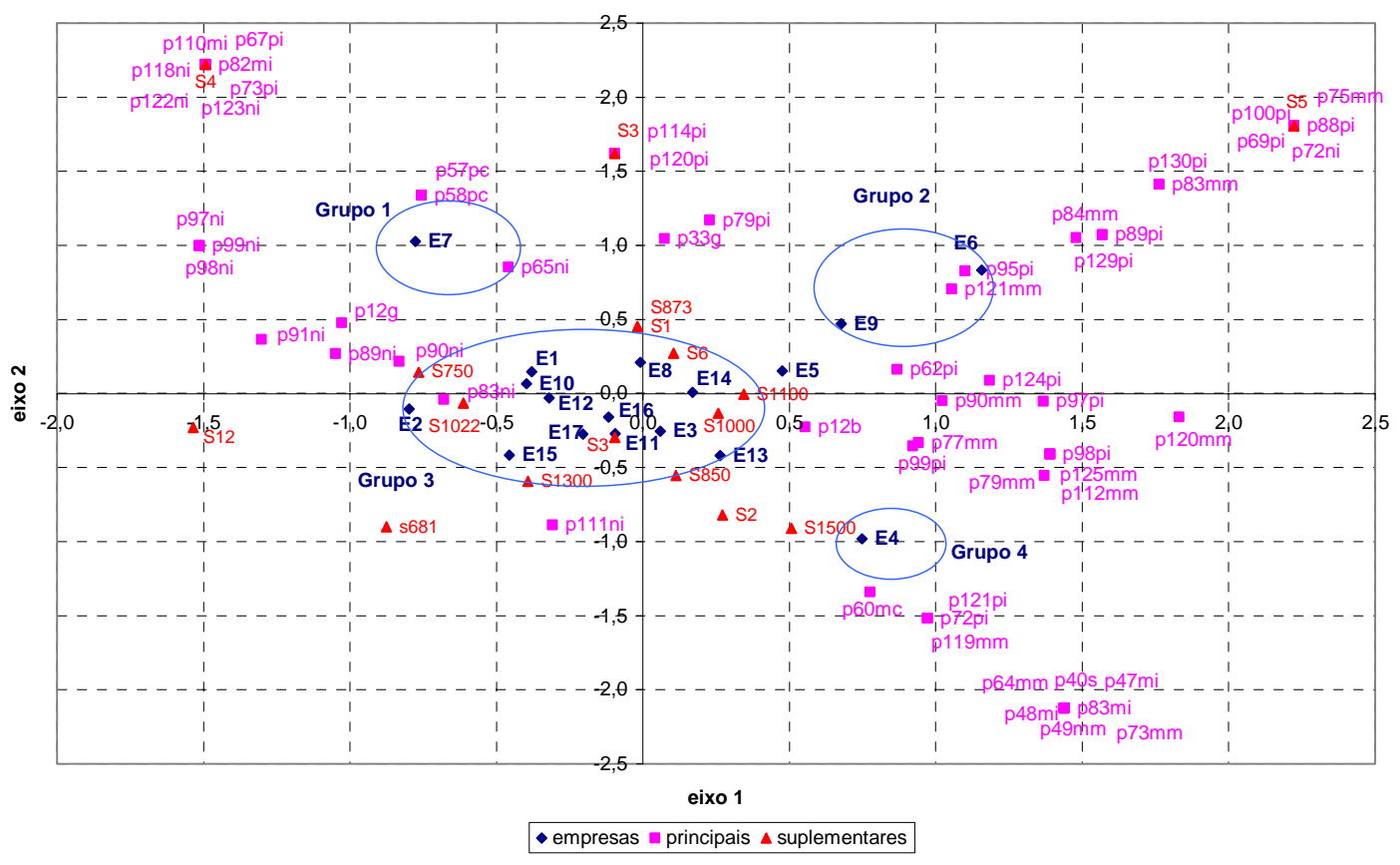

Figura 34 - Plano fatorial relacionando variáveis e observações

A partir das coordenadas dos pontos-perfis no plano fatorial e de suas contribuições relativas, foram relacionados grupos de modalidades e empresas de segurança privada, buscando estabelecer diferenças de perfis na prestação de serviços, compondo quatro grupos de empresas.

O primeiro grupo encontrado refere-se a uma empresa com características atípicas. É um prestador de serviços voltado para o setor público, sendo que o entrevistado desconsidera a investigação social, aparência física do indivíduo, sua capacidade de comunicação, indicações de funcionários e de outras empresas como indicadores importantes para a contratação. A empresa terceiriza a seleção de candidatos, uma das funções básicas na atividade de segurança privada. Pelo fato de atender o setor público, principalmente, a empresa prioriza mais o preço que a qualidade dos serviços, o que explicaria este resultado. A rotatividade da mão-de-obra é bastante elevada, com iniciativas de desligamento partindo dos trabalhadores, não havendo grande dificuldade de substituição dos desligados inclusive pelo porte da empresa, com mais de 2000 funcionários. Dentre as causas que contribuem para a freqüência de 
desligamentos, foram sobressaltadas as falhas graves dos vigilantes, como dormir em local de trabalho, embriaguez e tratamento descortês com o público; reprovação pela supervisão da empresa, principalmente no período de experiência; a tentativa do vigilante em procurar outras ocupações com melhor remuneração, quando alocados em postos de trabalho que não permitem o recebimento de horas-extras; o término do contrato de prestação de serviços, principalmente com o setor público cujas possibilidades de prolongamento da relação ficam limitadas pela necessidade de estabelecer processos licitatórios em que a negociação de termos é pouco flexível.

Afirmou-se na entrevista que a mão-de-obra empregada origina-se em grande parte de classes sociais com escolaridade e renda baixas, sendo observado, pelos registros nas carteiras de trabalho, que a ocupação de vigilante ainda oferece remuneração melhor que experiências anteriores de trabalho. Por outro lado, o entrevistado afirmou que muitos dos admitidos são originados de ocupações na indústria que passaram por redução de postos de trabalho, migrando para a profissão de vigilante porque a remuneração é maior que em ocupações com exigências de esforço similares, como porteiros e trabalhadores de serviços de conservação. Na entrevista ficou claro que trabalhadores com este perfil tendem a não se orgulhar da profissão, desligando-se freqüentemente da empresa na busca de ocupações em outras atividades.

No segundo grupo, destacam-se duas empresas (E6 e E9) que acreditam serem os preços dos serviços oferecidos pouco importantes para estimular clientes a lhes contratar. Afirmam que seus preços costumam estar acima dos praticados no mercado, sendo que na empresa E9 o entrevistado afirma ser comum a assinatura de contratos de prestação de serviços com vantagens financeiras oferecidas pelo cliente, permitindo, nesses casos, que a remuneração básica do vigilante seja maior que o piso da categoria. $\mathrm{Na}$ empresa E9, no entanto, o entrevistado afirma que a rotatividade de trabalhadores estaria em torno de $2 \%$ ao mês, enquanto na empresa E6 o entrevistado afirma que a rotatividade estaria em torno de $8 \%$. Acreditam serem seus funcionários melhor avaliados durante o período de experiência que durante o processo de seleção, considerando também que o fim contrato de prestação de serviços, a busca de outras oportunidades de trabalho, o estímulo dado pelo seguro desemprego e o interesse do 
funcionário em sacar o fundo de garantia são causas mais importantes de desligamentos dos funcionários que em outras empresas. A rotatividade de trabalhadores não é considerada uma fonte de insegurança por parte do cliente para essas empresas, que atendem condomínios e indústrias principalmente. Um dos entrevistados manifestou a idéia de que o vigilante não é leal à empresa, por uma visão pejorativa da profissão, que a empresa busca mudar.

O terceiro e maior grupo inclui a maior parte das empresas, que acreditam ser importante a manutenção da igualdade da remuneração, para evitar conflitos de interesses com funcionários e problemas na justiça com reclamações trabalhistas. $\mathrm{O}$ treinamento específico para o posto de trabalho é uma característica essencial neste grupo de prestadores, que também acreditam ser a rotatividade responsável por insegurança entre os clientes e por custo de treinamento de funcionários. Na sua maioria essas empresas acreditam que os funcionários são melhores reconhecidos durante o processo de seleção que durante o período de experiência, investindo em práticas de seleção mais rigorosas. Também acreditam que o preço é fundamental para conquistar novos clientes, reclamando da existência de empresas clandestinas que generalizam práticas ilegais no mercado de prestação de serviços.

O quarto grupo foi formado por uma empresa ligada com a promoção de eventos, que destaca-se das demais por permitir uma maior diferenciação de rendimentos em função da avaliação de clientes e de supervisores. Na amostra foi a única empresa onde o salário base do vigilante $(\mathrm{R} \$ 800,00)$ é superior ao salário base da categoria (R\$ $681,65)$.

Para melhor agrupar essas empresas foi utilizada a análise de cluster, a partir dos fatores gerados na análise de correspondência. Inicialmente procurou-se determinar o número ótimo de clusters com base no método hierárquico (Ward), com auxílio das seguintes estatísticas: homogeneidade do agrupamento (rmsstd - que deve ser o menor possível); perda de homogeneidade (spr - que deve ser a menor possível) e heterogeneidade entre conglomerados (rs - que deve ser o maior possível), conforme mostra a Figura 35. 


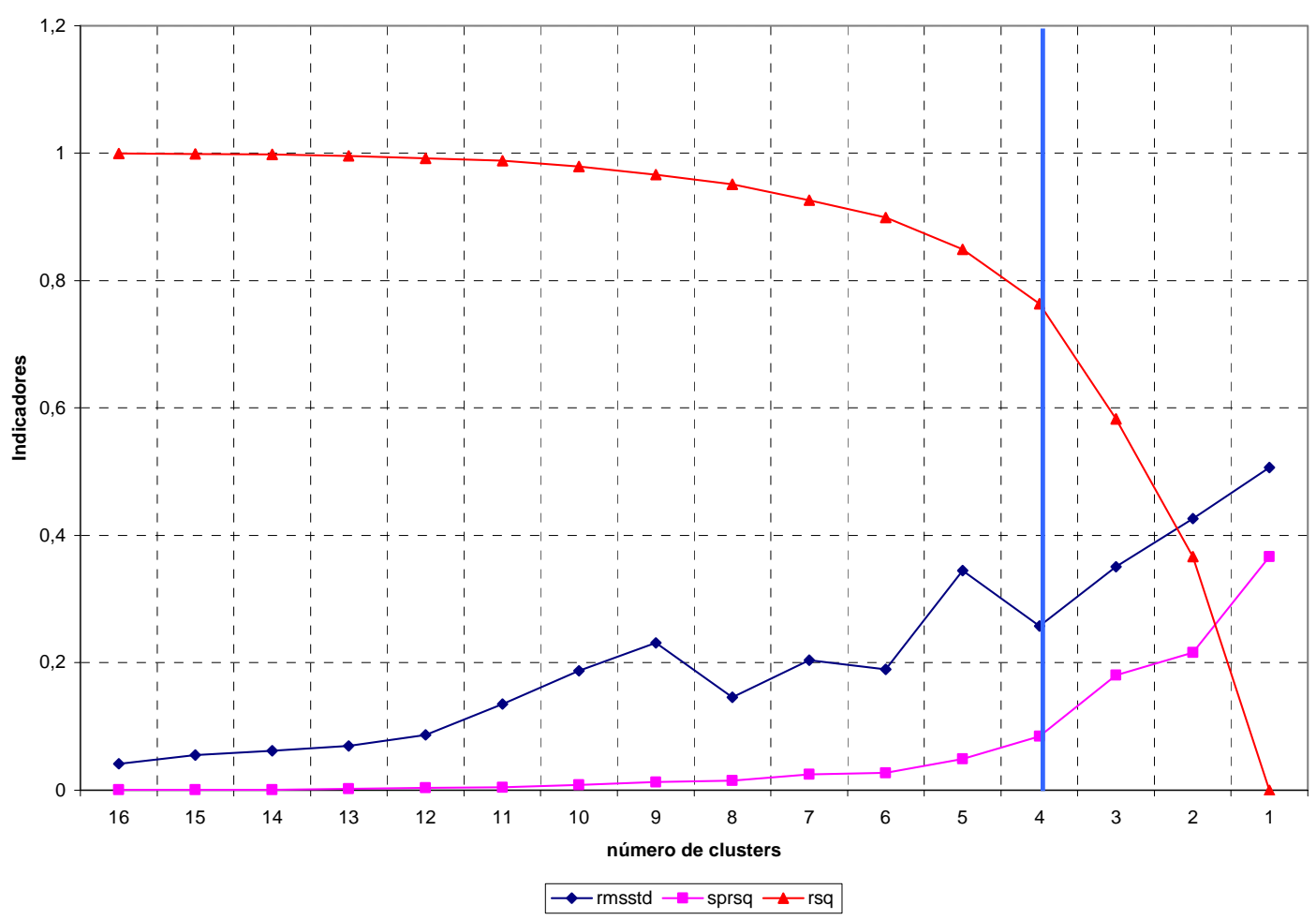

Figura 35 - Número de clusters pelo método de Ward

Pela Figura 35 determinou-se que o número ideal seria de quatro agrupamentos.

Com o intuito de melhor agrupar as empresas foi adotado o método nãohierárquico k-means que convergiu para a alocação de empresas em clusters apresentados na Tabela 6. 
Tabela 6. Empresas e Clusters

\begin{tabular}{lllll}
\hline $\begin{array}{l}\text { Distância } \\
\text { Obs }\end{array}$ & Empresa & Cluster & \multicolumn{2}{c}{ Origem } \\
\hline 1 & 1 & 2 & 0,33190 \\
& 2 & 2 & 2 & 0,60820 \\
3 & 3 & 4 & 0,28120 \\
& 4 & 3 & 0,00000 \\
5 & 5 & 3 & 0,44360 \\
5 & 6 & 1 & 0,52020 \\
7 & 7 & 2 & 0,00000 \\
8 & 8 & 3 & 0,38000 \\
9 & 9 & 2 & 0,09400 \\
10 & 10 & 2 & 0,28250 \\
11 & 11 & 2 & 0,17580 \\
12 & 12 & 2 & 0,16000 \\
13 & 13 & 2 & 0,54070 \\
14 & 14 & 2 & 0,38390 \\
15 & 15 & 2 & 0,08080 \\
16 & 16 & 2 & 0,14900 \\
\hline
\end{tabular}

$\mathrm{Na}$ análise de cluster, os grupos formados coincidiram os observados no gráfico com os eixos fatoriais, com exceção das empresas E5, que ficou agrupada com as empresas E6 e E9. O motivo desta união não ficou claro, mas da discussão anterior e do agrupamento pelo método $k$-means deixam transparente que as empresas, em sua maior parte, tem um comportamento comum. Os casos das empresas E4 e E7, que se distanciam das demais, revelam extremos de comportamento em que os perfis dos principais clientes atendidos têm um forte componente de alteração do comportamento: o setor público que busca menores preços e a questão da qualidade fica em segundo plano; e o segmento de eventos, em que a qualidade dos serviços fica ressaltada. É interessante notar que o prestador de serviços E4 é o único que paga salário base superior ao firmado em acordo coletivo, pretendendo aumentar o empenho do trabalhador e reduzir a rotatividade dos indivíduos. 


\section{CONCLUSÕES}

Problemas relacionados com assimetria de informação, características de bem público e externalidades no sistema de prestação de serviços de segurança privada justificam a intervenção estatal regulamentando ou provendo serviços. Acompanhando tendências observadas em sociedades democráticas ocidentais, no Brasil existe um processo de expansão da segurança privada com a oferta de serviços voltados à prevenção de crimes, pouco atendida pelo policiamento público. Cria-se uma ruptura cada vez maior com visões idealizadas que pregam a concentração dos serviços nas mãos do Estado ou da iniciativa privada, ganhando espaço a orientação pragmática de que os serviços podem ser integrados inclusive por seu aspecto distinto que vêm assumindo em termos de estratégias de prevenção, pela iniciativa privada, e estratégias de confronto, pelo setor público, que tem o uso da força legitimado, mas contido por procedimentos formais.

A demanda e a prestação de serviços de segurança privada tendem a persistir em função das falhas do Estado e das condições específicas para o funcionamento efetivo dos sistemas de segurança. O desenvolvimento das forças policiais, focalizando a especialização e o profissionalismo, é apontado como a causa de um distanciamento problemático entre essas e as comunidades atendidas, tornando serviços menos direcionados para a prevenção e mais para reação aos delitos.

A capacidade finita das forças de policiamento, em um ambiente urbano sob intensa transformação, criou oportunidades para o desenvolvimento de novas formas de organização de espaços de convivência coletiva em propriedades privadas, que substituem os espaços públicos no atendimento de demandas individuais por condições mais seguras de interação social e econômica. O desenvolvimento de shoppings centers, 
condomínios residenciais, comerciais e industriais, clubes e centros empresariais são exemplos de espaços sob controle da iniciativa privada que fazem uso de serviços de vigilância e impulsionam seu crescimento. A possibilidade de excluir indivíduos do consumo, com impedimento de acesso ou controle do uso dos recursos, através do monitoramento do espaço privado e da presença de vigilantes, aumenta a utilidade da segurança privada como recurso para prevenção de crimes. A capacidade de adaptação da segurança privada é também um grande diferencial em relação aos serviços públicos, sujeitos aos procedimentos formalizados.

No Brasil, no entanto, a atividade regular compete com um grande número de agentes clandestinos. Este elevado grau de clandestinidade tem relação com custos comparativamente menores de prestação de serviços, que por serem insumos indiretos de produção, configuram despesas que tomadores de serviços cortam em épocas de contenção de custos. O prestador de serviços clandestinos possui vantagens ao escapar dos custos criados pelas instituições no mercado de trabalho e dos custos e barreiras para ingresso e operação no mercado de prestação de serviços. Com falhas na fiscalização e punição de clandestinos, forma-se uma conjuntura desfavorável à atuação regular na segurança privada. Considerando que os custos de prestação de serviços são substancialmente maiores na atividade regular, e como tomadores com renda mais baixa têm menor a propensão a consumir, o emprego de agentes clandestino a baixo custo tende a ser atraente.

A investigação empírica revelou que a maioria dos integrantes do mercado apóia a aplicação dos regulamentos atuais na atividade, mas sentem que a concorrência com o ramo clandestino deteriora as condições da prestação de serviços e cria uma péssima imagem para o setor. O pessimismo de alguns leva a projeções de que grande parte do mercado será perdida para trabalhadores informais e ocupantes irregulares das funções de vigilante, como porteiros, cujo piso salarial é menor que o da categoria.

Para a qualidade dos serviços prestados por um vigilante contribuem atributos como honestidade, estabilidade emocional e atenção, que não são diretamente observáveis nem controlados pelo contratante. Neste caso, a assimetria de informações aumenta riscos e custos de transação, para todas as estruturas de governança presentes 
no sistema de prestação de serviços. Contudo, os mercados são particularmente frágeis nessas circunstâncias e a atividade clandestina reflete esta característica. Por não ser respeitada nenhuma exigência quanto aos atributos dos vigilantes, na atividade clandestina persiste uma grande incerteza quanto aos atributos individuais, que as empresas regulares buscam diminuir.

As principais alternativas para a aquisição de serviços de segurança seriam a integração vertical da atividade, na constituição serviços orgânicos, ou a constituição de uma forma híbrida, com a contratação de uma empresa prestadora de serviços de vigilância.

No primeiro caso, não investigado empiricamente, o contratante deve lidar com problemas de monitoramento, incentivos e superar problemas de assimetria de informações no mercado de trabalho, através de processos de recrutamento e seleção de trabalhadores. As empresas precisam constituir um corpo treinado para captar sinais de qualidade e avaliar os atributos individuais dos trabalhadores. O custo de administrar todo o processo de seleção e de monitorar trabalhadores ficaria a encargo do cliente final, que em contrapartida poderia realizar adaptações mais facilmente nas atividades dos vigilantes. Este tipo de investimento justifica-se quando há uma necessidade de ativos humanos mais específicos, com trabalhadores desempenhando tarefas não rotineiras.

A terceirização dos serviços, uma forma híbrida de governança das transações, seria uma alternativa em que o tomador de serviços não se preocupa com a administração direta dos trabalhadores. Abre-se mão, neste caso, de alguma capacidade de adaptação cooperativa, muito embora o prestador acredite ser fundamental treinar o trabalhador com conhecimentos específicos. As empresas buscam levantar informações sobre candidatos para inferir seus atributos em processos de seleção, além de avaliar requisitos individuais a partir de manuais de normas e procedimentos de segurança.

Percebeu-se que os entrevistados são favoráveis à elevação de requisitos mínimos de escolaridade como forma de aprimorar a qualidade dos serviços oferecidos no mercado como um todo, melhorando a reputação das empresas. Propõem também alterações em grades curriculares de cursos de formação. O reconhecimento da 
qualidade diferenciada tenderia a aumentar a propensão a pagar pelos serviços, como conseguem algumas empresas com marcas fortes, certificados e experiência no mercado. Contudo, a elevação da percepção sobre a qualidade dos serviços do segmento formal e o aumento da propensão a pagar pelos serviços dificilmente seriam suficientes para estimular a formalização de empresas sem revisão de encargos, tributos e custos em processos rescisórios.

O problema da reputação atinge diretamente pequenos empregadores e ressentem-se deste tipo de atuação porque problemas de atrasos nos recolhimentos costumam ser motivo de desconfiança e atrito com trabalhadores e clientes, que têm medo da firma desaparecer sem honrar seus compromissos. Além das dificuldades de criar uma boa reputação e usufruir ganhos de escala, a capacidade de pequenas empresas atraírem melhores trabalhadores e clientes fica abalada pelo comportamento indevido de outros participantes do mercado.

A capacidade de atração de bons trabalhadores parece ser diretamente relacionada com o tamanho da empresa por dois motivos. Em primeiro lugar, empresas com grande número de postos de trabalho poderiam, com maior facilidade, evitar demissões nos términos ou rompimentos de contratos de prestação de serviços, ou mesmo nos pedidos de substituição de trabalhadores. Caso seja necessário demitir, as empresas buscam manter seus melhores funcionários e melhorar a qualidade dos serviços. A segunda razão para empresas maiores atraírem mais trabalhadores estaria na maior segurança transmitida a esses de que suas obrigações seriam cumpridas, evitando danos em sua reputação.

A construção de uma boa reputação é ponto crucial para o sucesso das empresas com clientes do setor privado. A boa reputação consolida os esforços de construção de marcas e investimentos em certificação e propaganda, aumentando as possibilidades de conseguir assinar e prolongar relações com clientes e trabalhadores. $\mathrm{O}$ fortalecimento da relação com funcionários é também foco de criação de boa reputação, para minimizar o problema de seleção adversa de trabalhadores.

Existem problemas com a forte vinculação entre vigilantes e clientes, que as empresas muitas vezes reconhecem como causa de indisciplina. Um conflito pode existir 
entre prestador de serviços e cliente sobre a conduta do vigilante, indicando uma perda de controle sobre a capacidade de adaptação cooperativa do trabalhador ao serviço. Contudo, as tarefas de vigilância em si são pouco complexas, com a especificidade intermediária de capital humano nesta transação, viabilizando a forma híbrida na prestação do serviço.

Os entrevistados revelaram que as empresas preocupam-se em ajustar seus trabalhadores ao sistema de segurança, utilizando empregados na correção de falhas dos sistemas e na prevenção de delitos. O enfoque na prevenção mostra a função complementar da segurança privada com o policiamento público, que por seu distanciamento dos clientes, atua mais na reação às ocorrências. As empresas buscam manter bom relacionamento com a força policial para contar com seu auxílio na solução de ocorrências. Na ênfase dada por empresários à presença de supervisores está também a preocupação de reconhecer necessidades de adaptação dos serviços aos desígnios dos clientes.

Além da influência da barganha sindical na defesa de pisos salariais mais elevados, existe a concordância de parte dos empregadores em pagar remunerações relativamente mais altas para evitar falhas no comportamento dos indivíduos. O piso salarial oferece uma remuneração superior a alternativas que os indivíduos possuiriam por atuarem em atividades correlatas de portaria e de conservação. Além do piso salarial mais elevado, o pagamento de horas extraordinárias é freqüente na atividade, servindo de forte estímulo ao comportamento honesto dos trabalhadores e redução da rotatividade do trabalho. A idéia de salário de eficiência como forma de incentivo parece adequada ao caso.

Críticas à regulação referem-se à necessidade de racionalizar procedimentos de emissão e renovação de alvarás de funcionamento de empresas, de autorizações para compra de armas, munições e equipamentos, de emissão de carteiras de vigilantes para não colocar empresas em desvantagem nas concorrências por postos.

Os problemas da assimetria de informações atingem também o mercado de prestação de serviços terceirizados. A informação transmitida aos clientes depende também de sua sensibilidade aos problemas da contratação de empresas e trabalhadores 
clandestinos. Algum grau de investimento em educação do consumidor, que esclareça os cuidados na relação com contratados, precisa ser realizado para que processos de transparência de informações e de certificação de empresas sejam mais efetivos.

Embora recentes, iniciativas de certificação de empresas podem representar um avanço na diferenciação de prestadores de serviços que auxilie na promoção da atividade. Um código de conduta voluntariamente construído pode levar a uma contribuição efetiva, no que algumas iniciativas vêm sendo tomadas. A implementação de padrões privados pode trazer benefícios, mas a dimensão desses em comparação com os custos pode não ser compensadora, sendo mais importante, talvez, a aplicação da legislação no setor.

De especial interesse pode ser a revisão dos procedimentos de policiamento integrados com empresas de segurança. A transmissão de informações entre agentes pode contribuir substancialmente para a eficiência na resposta e na prevenção de delitos. Explorar externalidades positivas de sistemas de segurança privada sobre vizinhanças, aproveitando competências e agilizando a transmissão de informações, pode ser um foco de atuação de políticas de policiamento. 
ANEXOS 


\section{ANEXO A - O mercado de trabalho na presença da assimetria de informações}

Supondo que os trabalhadores conhecessem sua aptidão para o trabalho e que os empregadores não a observassem diretamente, Camargo (2002) tomou como pressuposições:

a) a produtividade dos trabalhadores semi-qualificados pode ser representada por um número real no intervalo $[0,1]$;

b) todas as produtividades apareceriam com igual probabilidade;

c) todos agentes seriam neutros ao risco.

No modelo, Camargo (2002) mostrou que uma relação de trabalho é estabelecida com um trabalhador de qualidade $k$ quando seu salário é um valor entre o mínimo que ele exige ( $\left.w^{\prime} k\right)$ e o máximo que o empregador propõe-se a pagar ( $w$ ”k). A relação de trabalho existiria quando o máximo que o empregador dispõe-se a pagar é igual ou maior que o mínimo exigido pelo trabalhador ( $w$ " $k \geq w^{\prime} k$ ), ou seja, quando $w$ ” $\geq w^{\prime}$.

Se os empregadores estivessem dispostos a pagar a taxa máxima de uma vez e meia a taxa mínima que os empregado estão propensos a receber $\left(w^{\prime}=3 / 2 w^{\prime}\right)$, o salário de mercado seria estabelecido pelo poder de barganha das partes. Quando os empregados detivessem todo o poder de barganha, a taxa de salário fixada pelo mercado seria $w=3 / 2 w$, enquanto que no momento em que os empregadores detivessem todo o poder de barganha, a taxa de salário firmada seria $w=w$ '.

Para qualquer taxa, no entanto, determinar-se-ia um ponto de corte para a qualidade da mão-de-obra ofertada e os indivíduos com produtividade mais elevada retirariam-se do mercado, por não acharem o salário atraente. Isto é, após fixada uma taxa $w$, a oferta de trabalho iria ser composta de trabalhadores cujo produto entre qualidade e taxa mínima de salário fosse menor ou igual ao salário de mercado $\left(w^{\prime} k \leq w\right)$, portanto, indivíduos com produtividade $k \leq w / w^{\prime}$.

Se existir total assimetria de informações entre empregadores e trabalhadores com relação à qualidade desses, os empregadores poderiam contratar empregados com produtividades que vão de zero a um (pressuposição 1) no caso de o salário ser suficientemente elevado. Para dado salário praticado no mercado e considerando que os 
valores de produtividades sejam desconhecidos e igualmente distribuídos (pressuposição 2), condiciona-se a disposição dos empregadores a pagar salários pelo valor médio das produtividades, que possuiriam valores uniformemente distribuídos entre zero e o limite superior w/w'. O valor médio desta distribuição uniforme de valores é: $\mathrm{K}=(0+\mathrm{w} / \mathrm{w}) / 2$

Se a empresa fixa o salário em função desta produtividade média que acredita receber, o salário máximo que um empregador dispõe-se a pagar seria w"K = w'[w/2w']. Considerando a relação w"=3/2w' já estabelecida, temos que w"K = 3/4w. Ou seja, a produtividade média que o empregador percebe leva à disposição deste pagar uma remuneração menor que o salário de mercado w. Assim, apenas trabalhadores com produtividade menor tenderiam a se apresentar para os postos de trabalho, pois o salário seria menor que o de mercado, reduzindo mais ainda o interesse das empresas em contratar os trabalhadores. No caso extremo, o mercado tende a não existir. 


\section{ANEXO B - Questionário}

\section{Pesquisa sobre o relacionamento entre clientes, empresas e trabalhadores de segurança privada}

Nome Empresarial:1]

CNPJ:2

Logradouro: 3

Município:4

$\mathrm{UF}: 5$

CEP: 6

Nome do entrevistado: 7

Cargo:8

E-mail para contato:9

Telefone/Fax: 10

1. a) Qual a distribuição percentual de seu faturamento originado dos seguintes tipos de clientes e

b) Qual tempo médio de duração dos contratos em anos (incluindo renovações)

\begin{tabular}{|c|c|c|c|c|c|c|c|c|}
\hline & \multirow{2}{*}{$\begin{array}{c}\text { Setor } \\
\text { Público }\end{array}$} & \multicolumn{7}{|c|}{\begin{tabular}{|l} 
Setor Privado \\
\end{tabular}} \\
\hline & & Indústria & $\begin{array}{l}\text { Instituições } \\
\text { Financeiras }\end{array}$ & $\begin{array}{l}\text { Condomín } \\
\text { os }\end{array}$ & $\begin{array}{l}\text { Comércio e } \\
\text { Shopping's } \\
\text { Centers }\end{array}$ & Escolas & Hospitais & $\begin{array}{l}\text { OUTROS } \\
11\end{array}$ \\
\hline $\begin{array}{l}\text { a) Distribuição } \\
\text { do faturamento } \\
\text { por tipo de } \\
\text { cliente }\end{array}$ & $\begin{array}{ll} & \% \\
12 & \\
\end{array}$ & $\%$ & $\% 14$ & $\%$ & $\% 16$ & $\%$ & $\% 18$ & $\% 19$ \\
\hline $\begin{array}{l}\text { b) Número de } \\
\text { anos }\end{array}$ & 20 & 21 & 22 & 23 & 24 & 25 & 26 & 27 \\
\hline
\end{tabular}

2. Clientes costumam contratar seus serviços com preços superiores aos comumente praticados no mercado? 28

íMuito comum i Mais ou menos iPouco comum i Não

3. Qual é o número de empregados e a rotatividade por função dos trabalhadores:

\begin{tabular}{|c|c|c|}
\hline Função & $\begin{array}{l}\text { Número de } \\
\text { funcionários }\end{array}$ & $\begin{array}{l}\text { Rotatividade (Turnover)* } \\
\text { de trabalhadores por mês }\end{array}$ \\
\hline Administrativo & 29 & XX XX XX \\
\hline Supervisor & 30 & $31 \quad \%$ \\
\hline Vigilantes em Segurança Patrimonial & 32 & $\%$ \\
\hline Vigilantes em Transporte de Valores & 34 & $\%$ \\
\hline Vigilantes em Escolta Armada & 36 & $\%$ \\
\hline Vigilantes em Segurança Pessoal & 38 & $\%$ \\
\hline
\end{tabular}

* Rotatividade representa o número normalmente observado de vigilantes admitidos para substituir os demitidos em um mês, dividido pelo total de vigilantes. 
4. Na maioria dos postos da empresa, a remuneração básica dos vigilantes em segurança patrimonial é superior ao salário base da categoria (atualmente em R\$ 681,65)?:40

i Não. i Sim. Se sim, qual seria o valor básico de sua remuneração? 41 RS

5. Na sua empresa, a que valor pode chegar uma remuneração diferenciada de um vigilante em segurança patrimonial se o cliente assinar um contrato com vantagem financeira? $42 \mathrm{R} \$$

6. Na sua empresa, qual o valor médio da remuneração de vigilantes em segurança patrimonial, incluindo horas extras e benefícios? $43 \mathrm{R} \$$

7. Entre vigilantes no mesmo posto e com as mesmas funções, jornadas, turnos e dias trabalhados, o quão importante seriam os fatores abaixo na diferenciação das remunerações:

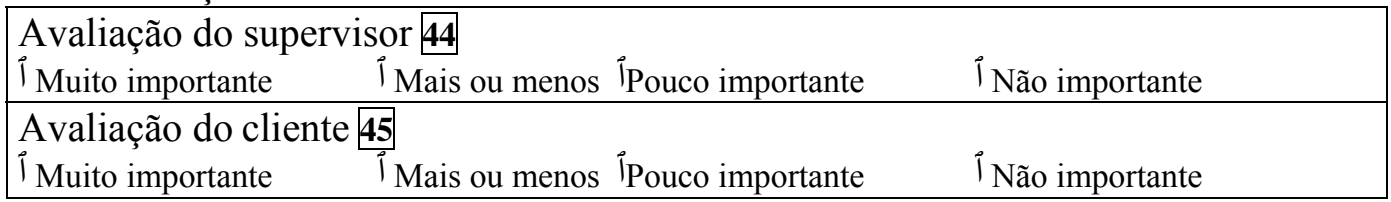

8. Na sua empresa, para indivíduos com a função de vigilante patrimonial, qual seria o grau de importância dos fatores abaixo na elevação da remuneração?

Cliente oferece vantagem financeira em relação ao mercado 46

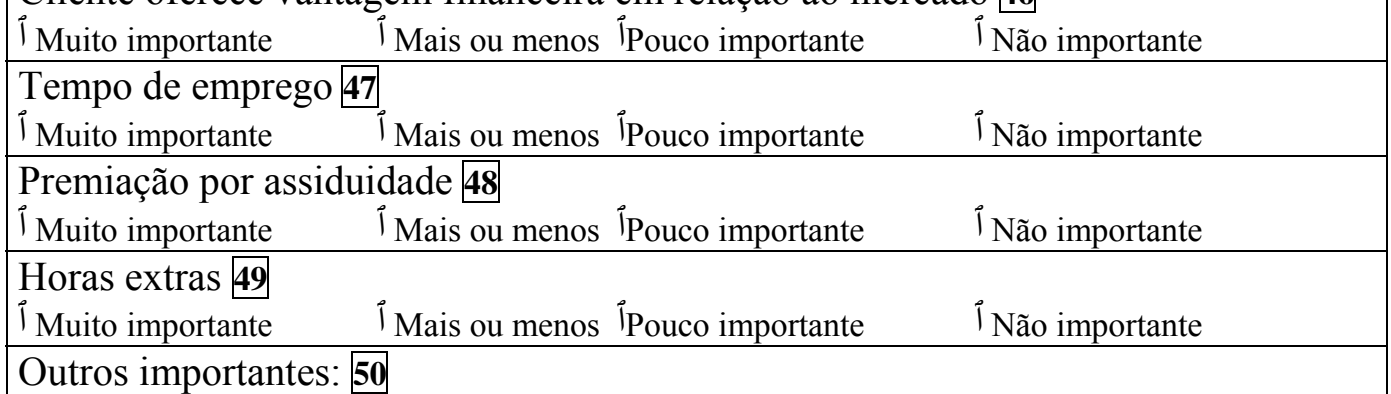

9. Quando um cliente deseja que um vigilante seja substituído, qual a situação mais freqüentemente observada? 51

lo vigilante é demitido. I O vigilante é alocado em outro cliente. İNão sabe

10. Em relação aos tipos de clientes da empresa relacionados a seguir, é comum que solicitem a substituição de vigilantes:

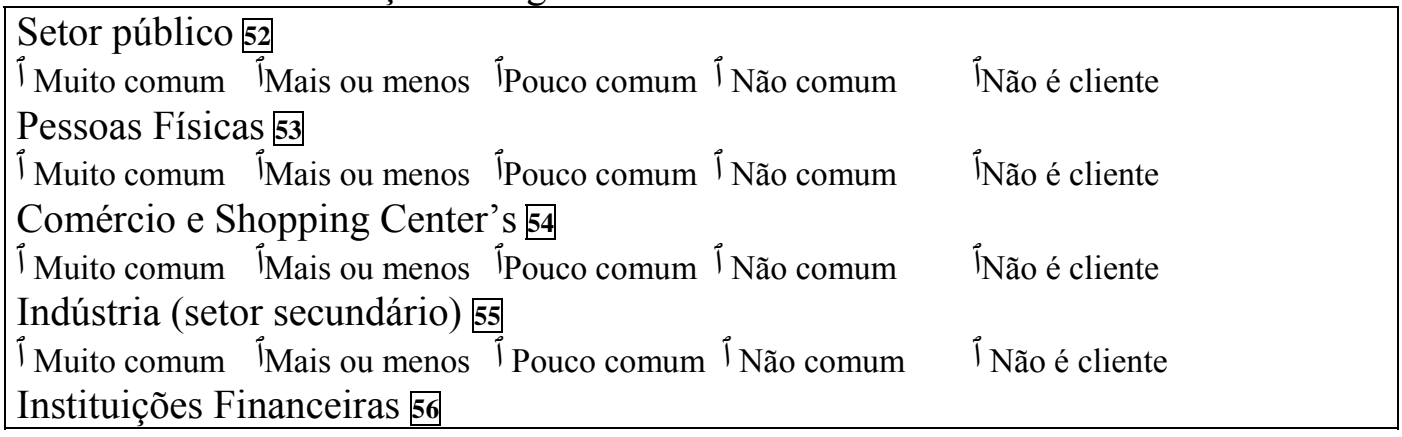




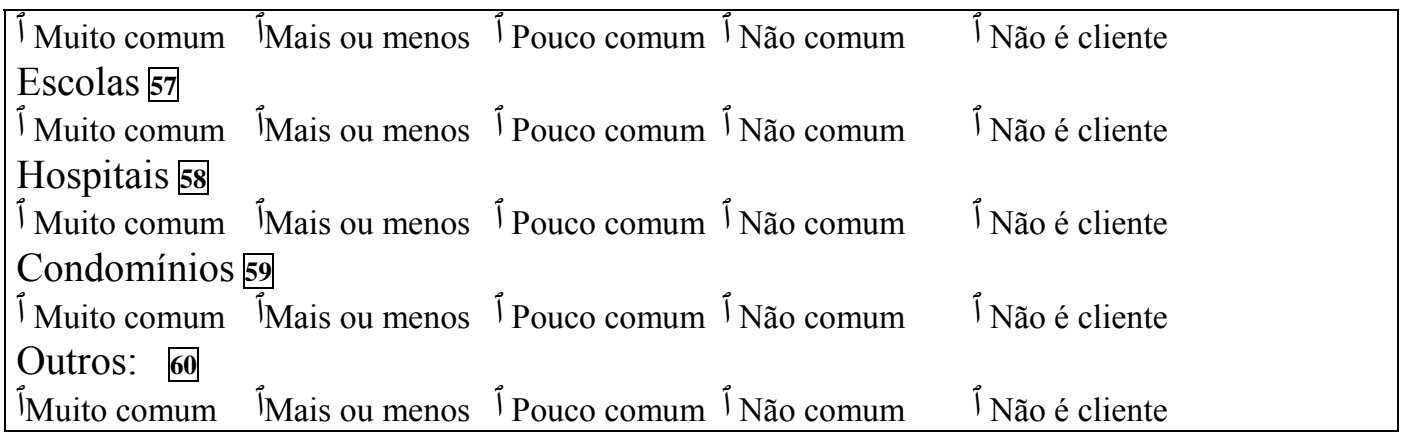

11. É comum que a conduta do vigilante crie um forte vínculo entre este e o cliente, que fixa o indivíduo no posto de trabalho? 61

i Muito comum i Mais ou menos i Pouco comum i Não comum

12. Esta fixação do empregado no posto pode ocasionar problema: 62

I Muito importante I Mais ou menos importante I Pouco importante I Não importante

Porquê seria um problema?63

13. Na sua empresa, para vigilantes com remuneração superior às alternativas que encontrariam no mercado, quais as conseqüências mais importantes:

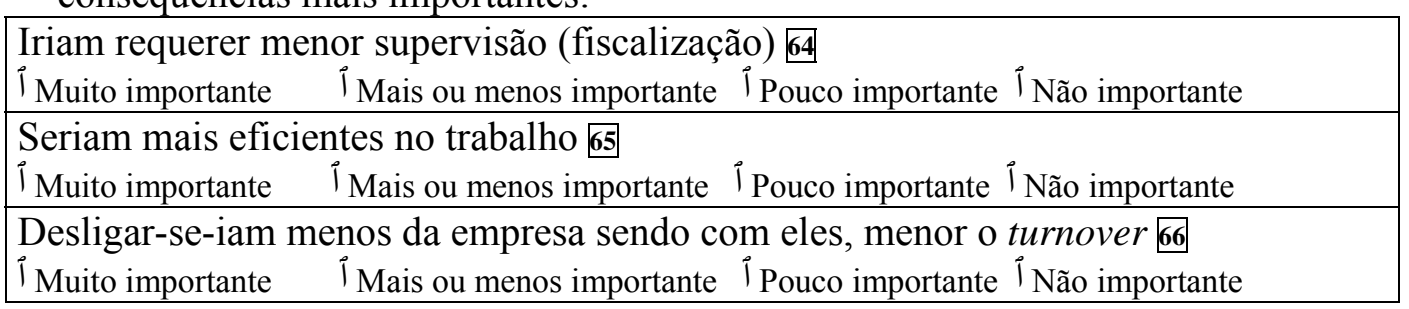

14. $\mathrm{Na}$ sua empresa, dentre os fatores abaixo, qual o grau de importância para a qualidade dos serviços prestados pelo vigilante:

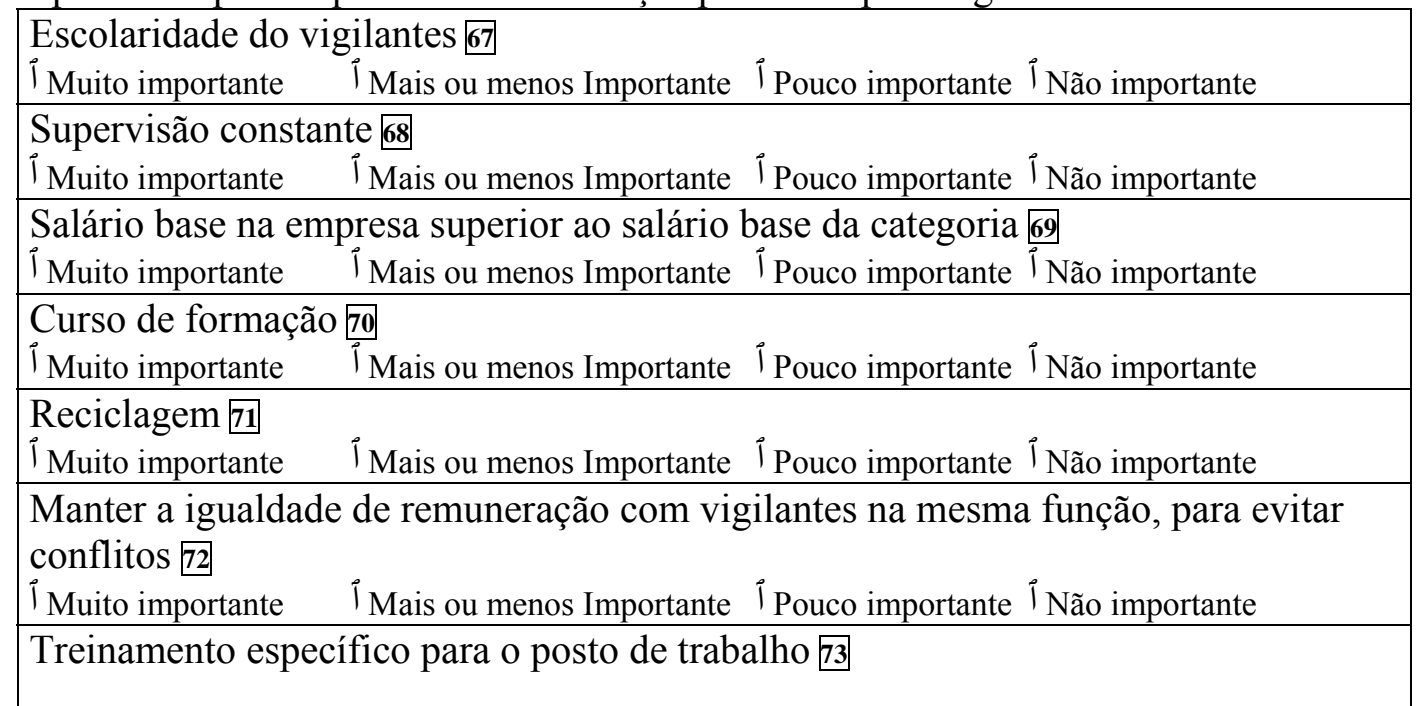




\begin{tabular}{|l|l|}
\hline I Muito importante $\quad$ Mais ou menos Importante I Pouco importante I Não importante \\
\hline Outros importantes:74 \\
\hline
\end{tabular}

15. Na sua empresa, quais os fatores mais contribuem para a freqüência de desligamentos de vigilantes?

Vigilante dormiu em local de trabalho ou cometeu erro grave.75

i Muito importante i Mais ou menos Importante i Pouco importante i Não importante

Vigilante não foi aprovado pela supervisão da empresa.76

i Muito importante i Mais ou menos Importante i Pouco importante li Não importante

Vigilante não foi aprovado pelo cliente 77

i Muito importante i Mais ou menos Importante i Pouco importante í Não importante

Vigilante alega que pretende buscar outras oportunidades de salário.78

i Muito importante i Mais ou menos Importante i Pouco importante i Não importante

Vigilante não se adaptou às exigências de esforço físico do posto 79

i Muito importante i Mais ou menos Importante i Pouco importante i Não importante

Vigilante não se adaptou aos turnos de trabalho $\mathbf{8 0}$

i Muito importante i Mais ou menos Importante i Pouco importante ${ }^{i}$ Não importante

Contrato de prestação de serviços foi terminado 81

i Muito importante i Mais ou menos Importante i Pouco importante i Não importante

Vigilante busca outra carreira 82

i Muito importante i Mais ou menos Importante i Pouco importante i Não importante

Vigilante acredita que será mandado embora com o fim do contrato de prestação

dos serviços. 83

i Muito importante i Mais ou menos Importante i Pouco importante i Não importante

Vigilante sente-se estimulado pelo seguro desemprego.84

i Muito importante i Mais ou menos Importante i Pouco importante i Não importante

Vigilante sente-se estimulado por oportunidades de indenização na justiça

trabalhista e provoca a demissão. 85

i Muito importante i Mais ou menos Importante i Pouco importante i Não importante

Outros importantes: 86

16. Na sua empresa, quais fatores mais contribuem para reduzir a rotatividade de vigilantes?

Plano de carreira, se existir, ou ascensão para outras funções. 87

i Muito importante i Mais ou menos Importante i Pouco importante i Não importante

Premiação por assiduidade no trabalho. 88

i Muito importante i Mais ou menos Importante i Pouco importante ì Não importante

Grande número de clientes, assegurando ao empregado uma colocação em algum posto.89

I Muito importante i Mais ou menos Importante i Pouco importante i Não importante

Turnos de trabalho adequados ao interesse do vigilante 90

i Muito importante i Mais ou menos Importante i Pouco importante í Não importante

Escala de trabalho adequada ao interesse do vigilante 91 


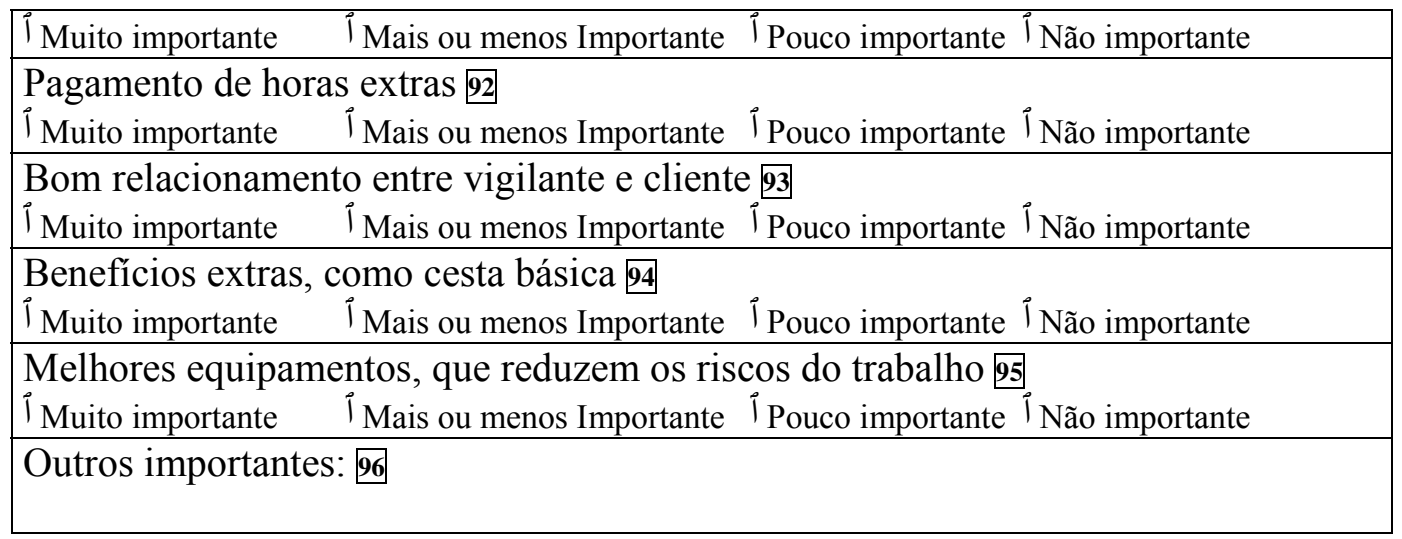

17. Na sua empresa, qual seria a importância dos seguintes problemas causados pela rotatividade dos trabalhadores:

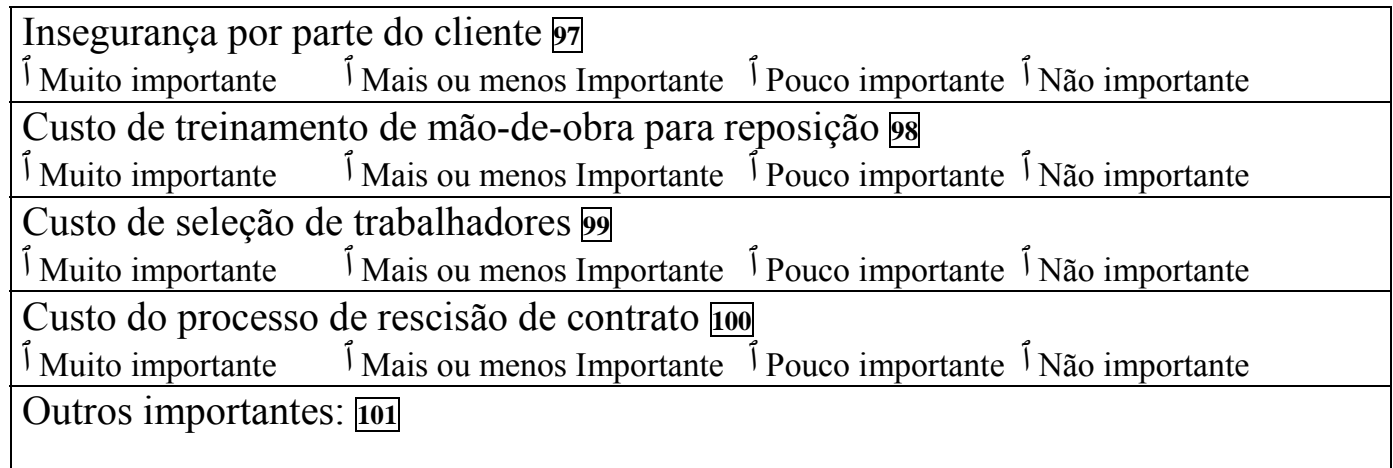

18. Em relação aos novos funcionários:

A qualidade do trabalhador é melhor observada durante o período de experiência que durante o processo de seleção? 102

i Sim i Não

A contratação errada de trabalhadores costuma causar problemas graves para a empresa? 103

i Sim i Não

Por quantos meses, em média, sua empresa precisa avaliar um vigilante para estar segura de sua aptidão ao trabalho?

104 meses. 105 i Não sabe

Dentre os desligamentos* na empresa, que percentual você atribuiria a desligamentos de vigilantes com até 6 meses de trabalho?

$106 \%$. 107 i Não sabe

Que percentual você atribuiria* a desligamentos de vigilantes com tempo de trabalho entre 6 meses e um ano?

$108 \%$ 109 înão sabe 
*por iniciativa do empregado ou do empregador.

19. Na sua empresa, quais são os meios mais utilizados na seleção de candidatos:

Seleção terceirizada. 110

i Muito utilizado i Mais ou menos utilizado i Pouco utilizado ÍNão utiliza

Divulgação ampla dos processos de seleção, como em jornais. 111

i Muito utilizado i Mais ou menos utilizado i Pouco utilizado ínão utiliza

Consulta a cursos de formação. 112

íMuito utilizado i Mais ou menos utilizado i Pouco utilizado íNão utiliza

Candidatos que buscam as empresas por iniciativa própria. $\mathbf{1 1 3}$

i Muito utilizado i Mais ou menos utilizado i Pouco utilizado ínão utiliza

Levantamento sistemático de candidatos junto aos funcionários. 114

í Muito utilizado í Mais ou menos utilizado i Pouco utilizado İ Não utiliza

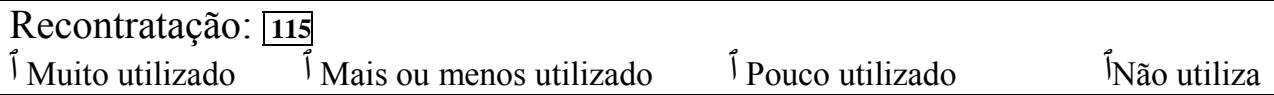

Outros importantes: $[116$

20. A empresa forma banco de dados para classificar candidatos? 117

i Sim înão

21. Na sua empresa, qual seria o grau de importância dos fatores abaixo para contratar um candidato:

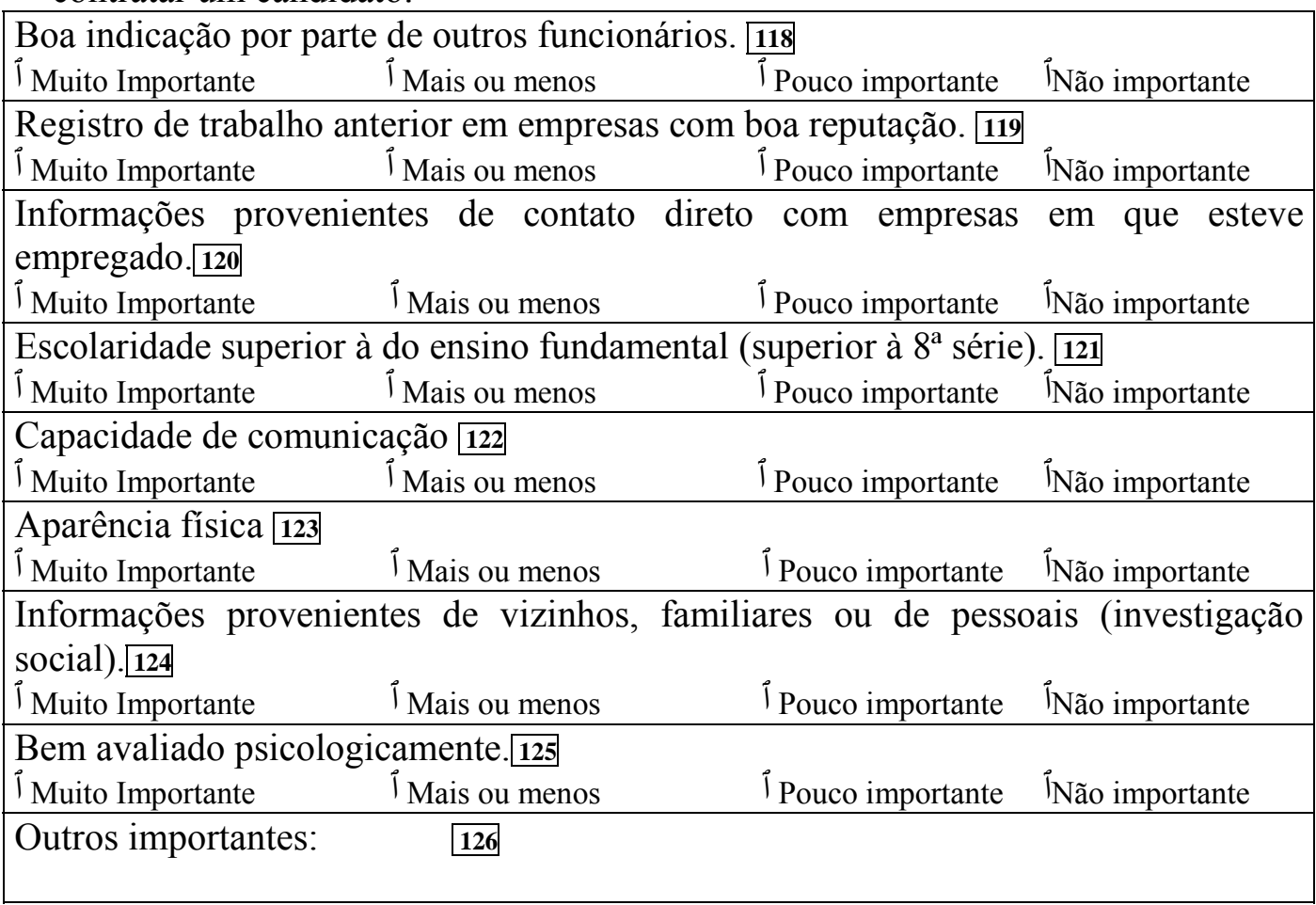

22. Para sua empresa, qual tem sido o grau de importância dos seguintes fatores para estimular clientes a lhe contratarem: 


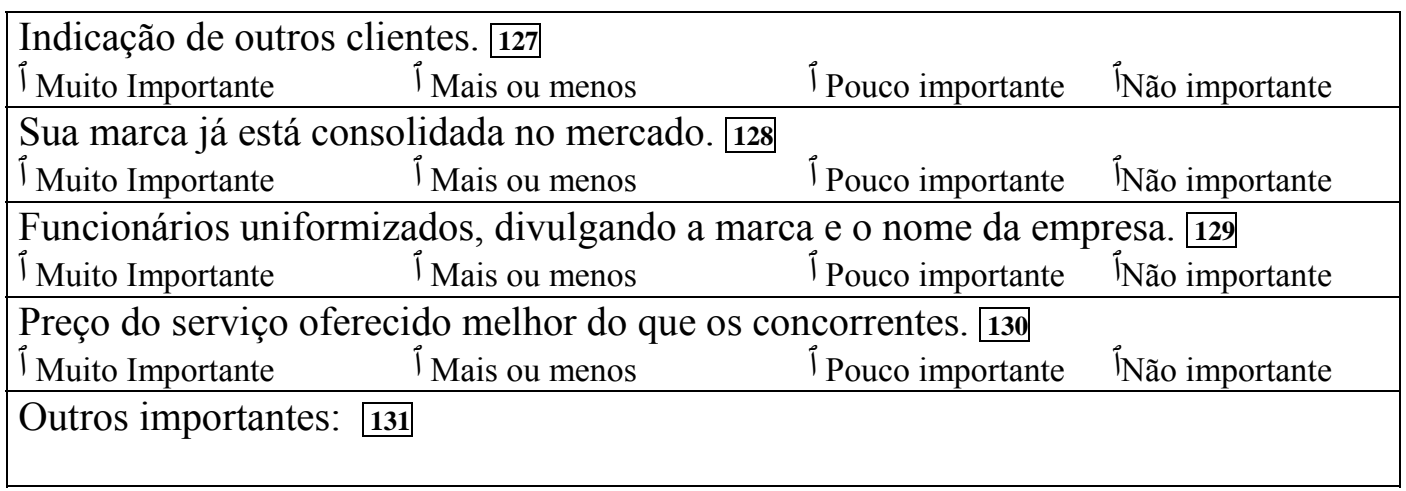

23. Para sua empresa, qual é o grau de importância dos fatores abaixo na melhoria de sua reputação perante os clientes:

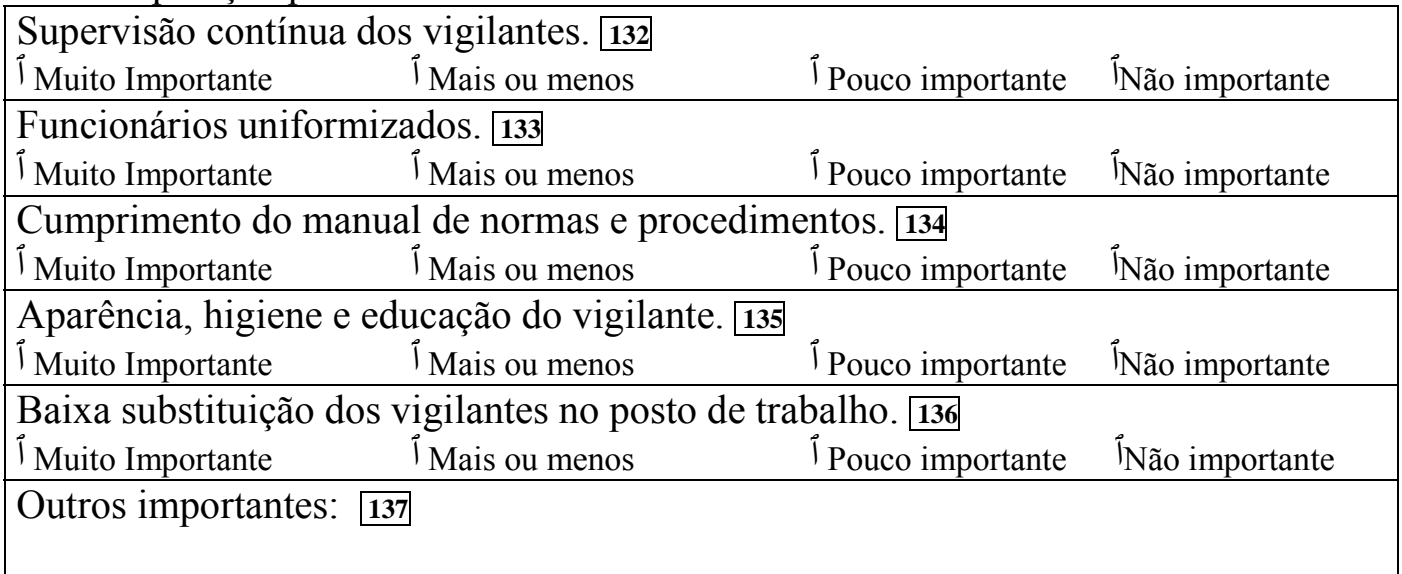

Brevemente, consegue imaginar mudanças que poderiam ser importantes em termos de legislação, representação sindical, ou institucional?

Comentários e sugestões: 138 


\section{REFERÊNCIAS BIBLIOGRÁFICAS}

ALCHIAN, A. Some economics of property rights. Santa Monica: RAND Corporation, $1961.30 \mathrm{p}$.

AKERLOF, G.A. The market of lemons: qualitative uncertainty and the market mechanism. Quarterly Journal of Economics, v.84, n.1, p.488-500, 1970.

ANEFALOS, L.C. Gerenciamento de frotas do transporte rodoviário de cargas utilizando sistemas de rastreamento por satélite. Piracicaba, 1999. 134p. Dissertação (Mestrado) - Escola Superior de Agricultura "Luiz de Queiroz", Universidade de São Paulo.

ARROW, K.J. The organization of economic activity: issues pertinent to the choice of market versus nonmarket allocation. In: HOOK, S. Human values and economic policy. New York: New York University Press, 1967. p.117-119.

BAYLEY, D.H.; SHEARING, C.D. The new structure of policing: description, conceptualization, and research agenda. Washington: U.S. Department of Justice, 2001. 50p. http://www.ncjrs.org/pdffiles1/nij/187083.pdf(15 Mar. 2004)

BENZÉCRI, J.P. Correspondence analysis handbook. New York: Marcel Dekker, 1992. 665p.

BRASIL. Ministério do Trabalho e Emprego. Relação anual das informações sociais (compact disc). Brasília, 1989-2002.

CALDEIRA, T.P.R. Cidade de muros: crime, segregação e cidadania em São Paulo. São Paulo: EDUSP, 2000. 400p. 
CAMARGO, J.M. Assimetria de informação e desemprego. Apresentado ao Seminário La Lucha Contra el Desempleo: experiencias internacionales, Bogotá, 2002.http://www.banrep.gov.co/economia/semin-lucha-contradesempleo/Camargo. pdf (05 ene. 2004)

CHRISTIE, N. A indústria do controle do crime. Rio de Janeiro: Forense, 1998. 287p.

COASE, R. The nature of the firm. In: COASE, R. The firm, the market and the law. Chicago: University of Chicago Press, 1988. p.33-55.

COASE, R. The federal communications commission. Journal of Law and Economics, v.2, n.1, p.1-40, 1957.

COASE, R.H. The problem of social cost. Journal of Law and Economics, v.3, n.1, p.1-44, 1960.

CONCEIÇÃO, M.C.V. A terceirização e sua controvérsia jurídica: uma leitura do caso da Volkswagen do Brasil, São Bernardo do Campo, 2002. 160p. Monografia (Graduação) - Faculdade de Direito de São Bernardo do Campo.

CRIVISQUI, E.M. Analisi factorial de correspondencias: un instrumento de investigación en ciencias sociales. Asunción: Universidad Católica "Nuestra Señora de la Asunción”, 1993. 302p.

CRIVISQUI, E.M. Apresentação dos métodos de classificação. Seminário de métodos estatísticos multivariados aplicados às ciências humanas. Campinas: UNICAMP, 1998. p.1-57.

CRIVISQUI, E.M.; BATISTA, C. Apresentação da análise fatorial de correspondência simples. Seminário de métodos estatísticos multivariados aplicados às ciências humanas. Campinas: UNICAMP, 1998. p.1-104.

CUBAS, V.O. A expansão das empresas de segurança privada em São Paulo. São Paulo, 2002. 167p. Dissertação (Mestrado) - Faculdade de Filosofia, Letras e Ciências Humanas, Universidade de São Paulo.

DEMSETZ, H. Toward a theory of property right. American Economic Review, v.57, n.1, p.347-373, 1967.

DILLON, W.R.; GOLDSTEIN, M. Multivariate analysis methods and applications. New York: Wiley, 1984. 587p. 
EGGERTSSON, T. Economic behaviour and institutions. Cambridge: Cambridge University Press, 1990. 385p.

ESCOFIER, B.; PAGÈS, J. Análisis factoriales simples y múltiples: objetivos, métodos e interpretación. Bilbao: Universidad del Pais Vasco, 1992. 285p.

ESTUDO do setor da segurança privada. São Paulo: FENAVIST, 2004. 185p.

FORST, B. Boundary changes in criminal justice organizations. Washington: National Institute of Justice, 2000. p.19-79: The privatization and civilianization of policing. (National Institute of Justice 2000 series)

GONZAGA, G. Labor turnover and labor legislation in Brazil. Rio de Janeiro: PUCRio, Departamento of Economia, 2003. 47p. (Texto para Discussão, 475)

GREENACRE, M.J. Theory and applications of correspondence analysis. Orlando: Academic Press, 1984. 364p.

HAIR, J.F.; ANDERSON, R.E.; TATHAM, R.L.; BLACK, W.C. Multivariate data analysis with readings. New Jersey: Prentice-Hall, 1995. 745p.

HARDIN, G. The tragedy of the commons. Science, v.162, n.1, p.1243-1248, 1968.

INSTITUTO BRASILEIRO DE GEOGRAFIA E ESTATÍSTICA. Pesquisa nacional por amostra de domicílios (compact disc). Rio de Janeiro, 1993-2002.

INSTITUTO BRASILEIRO DE GEOGRAFIA E ESTATÍSTICA. Pesquisa anual de serviços (compact disc). Rio de Janeiro, 1998-2001.

KATZ, L.F. Efficiency wage theories: a partial evaluation. Massachusets: NBER, Apr. 1986. 20p. (Working Paper, W1906). http://ssrn.com/abstract=24 (09 May 2004)

KEMPA, M.; STENNING, P.; WOOD, J. Policing communal spaces: a reconfiguration of the 'mass private property' hypothesis. British Journal of Criminology, v.44, n.3, p.562-581, 2004.

KLEIN, B.; CRAWFORD, R.G.; ALCHIAN, A.A. Vertical integration, appropriable rents, and the competitive contracting process. Journal of Law and Economics, V.21, n.2, p.297-376, 1978.

LAZEAR, E.P. Personnel economics. Cambridge: MIT Press, 1995. 207p.

LEIBENSTEIN, H. Economic backwardness and economic growth. New York: John Wiley \& Sons, 1957. 295p. 
LOADER, I.; WALKER, N. Policing as a public good: reconstuting the connections between policing and the state. Theoretical Criminology, v.5, n.1, p.9-35, 2001.

LYONS, B.R. Contracts and specific investment: an empirical test of transaction cost theory. Journal of Economics \& Management Strategy, v.3, n.2, p.257-278, 1994.

MACHADO, E.L. O papel da reputação na coordenação vertical da cadeia produtiva de frutas, legumes e verduras frescos. São Paulo, 2002. 182p. Tese (Doutorado) Faculdade de Economia, Administração e Contabilidade, Universidade de São Paulo.

MASTEN, S.E. Transaction cost economics and the organization of agricultural transactions. /Presented to World Food Systems Project Symposium, Chicago, $1991 /$

MILGROM, P.; ROBERTS, J. Economics, organization and management. New Jersey: Prentice-Hall, 1992. 621p.

MUSUMECI, L. Serviços privados de vigilância e guarda no Brasil: um estudo a partir de informações da PNAD (1985-1995). Rio de Janeiro: IPEA/DIPES, maio 1998. 90p. (Texto para Discussão, 560)

NELSON, P. Information and consumer behavior. Journal of Political Economy, v.78, n.2, p.311-329, 1970.

NELSON, R.H. The rise of private neighborhood associations: a constitutional revolution in local government. /Presented to Conference "Property Tax, Land Use and Land-Use Regulation", Arizona, 2000/ http://www.puaf.umd.edu/faculty/ papers/nelson/Lincoln\%20\%20The\%20Rise\%20of\%20Private\%20Neighborhood\% 20Associations3.pdf (25 June 2004)

NOGUEIRA, A.C.L. Custos de transação e arranjos institucionais alternativos: uma análise da avicultura de corte no estado de São Paulo. São Paulo, 2003. 153p. Dissertação (Mestrado) - Faculdade de Economia, Administração e Contabilidade, Universidade de São Paulo.

NORTH, D. Institutions, institutional change and economic performance. Cambridge: Cambridge University Press, 1990. 152p. 
NORTH, D. Transaction costs through time. Washington: Washington University Press, 1994. 10p.

NORTH, D. Institutions, transaction costs and productivity in the long run. St. Louis: Washington University, 1995. 10p.

PAIXÃO, A.L. Segurança privada, direitos humanos e democracia. Novos Estudos Cebrap, n.31, p.131-41, 1991.

PINO, F.A.; CASER, D.V. Falta de resposta em levantamentos por amostragem: um estudo de caso. São Paulo: IEA, 1984. 25p. (Relatório de pesquisa)

RANDALL, A. Resource economics: an economic approach to natural resource and environmental policy. New York: John Wiley \& Sons, 1987. 434p.

RILEY, J. Silver signals: twenty-five years of screening and signaling. Journal of Economic Literature, v.34, n.2, p.432-478, June 2001.

SANDLER, T. Collective action theory and application. Ann Arbor: The University of Michigan Press, 1995. 237p.

SHAPIRO, C.; STIGLITZ, J.E. Equilibrium unemployment as a worker discipline device. American Economic Review, v.74, n.3, p.433-444, 1984. http://www.jstor.org/fcgi-bin/jstor/listjournal.fcg/00028282/.71-.80 (03 Apr. 2004)

SHARMA, S. Applied multivariate techniques. New York: John Wiley \& Sons, 1996. 493p.

SHEARING, C.; STENNING, P. Private security: implications for social control. In: McCORMICK, K.R.E.; VISANO, L.A. Understanding policing. Toronto: Canadian Scholars Press, 1992. p.521-544.

SHERAFAT, F.L. Produtividade na ótica do trabalhador: uma análise dos aspectos que afetam o desempenho, criatividade e auto-estima dos funcionários no ambiente de trabalho. Florianópolis, 2002. 107p. Dissertação (Mestrado) - Faculdade de Engenharia de Produção, Universidade Federal de Santa Catarina.

SIMON, H. Models of man. New York: Wiley, 1957. 138p

SPENCE, M. Job market signalling. Quarterly Journal of Economics, v.87, n.3, p.355374, 1973. 
SPENCE, M. The economics of internal organization: an introduction. The Bell Jounal of Economics, v.6, n.1, p.163-172, 1975.

STIGLITZ, J.E. Imperfect information, credit markets and unemployment. European Economic Review, v.31, n.1, p.444-456, 1987.

STIGLITZ, J.E. The contributions of the economics of information to twentieth century economics. The Quarterly Journal of Economics, v.115, n.4, p.1441-1478, Nov. 2000.

TROJANOWICZ, R.C.; CARTER, D. Philosophy and role of community policing. Washington: U.S. Department of Justice, National Institute of Justice, 1988. 22p.

VINING; A.R.; GLOBERMAN, S. A conceptual framework for understanding the outsourcing decision. Washington, Apr. 1999. 30p. (Working paper) http://www.sfu.ca/mpp/faculty_staff/biographies/pdf_files/outsourc.pdf (02 June 2004)

WILLIAMSON, O.E. The economic institutions of capitalism: firms, markets, relational contracting. New York: The Free Press, 1985. 450p.

WILLIAMSON, O.E. The mechanisms of governance. New York: Oxford University Press, 1996. 429p.

ZYLBERSZTAJN, D. Estruturas de governança e coordenação do agribusiness: uma aplicação da Nova Economia das Instituições. São Paulo, 1995. 241p. Tese (Livre-Docência) - Faculdade de Economia, Administração e Contabilidade, Universidade de São Paulo. 